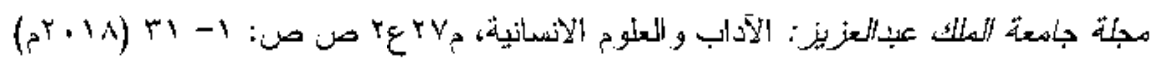
DOI:10.4197/Art.27-2.1

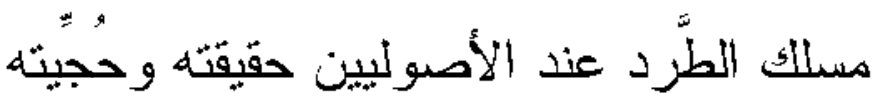 \\ د. بلقاسم بن ذاكر بن محمد الزّبيدي
}

أستاذ أصول الققه المساعد بجامعة الملاك عبد العزيز بجدة

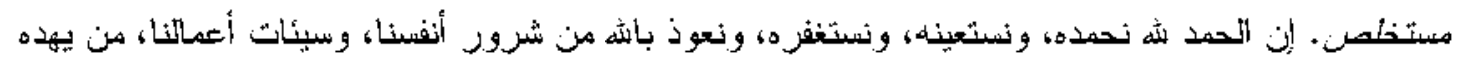

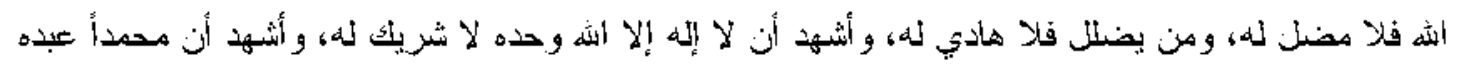

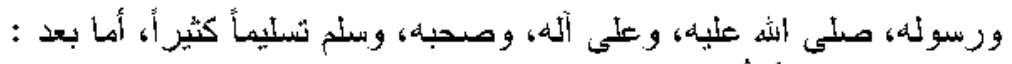

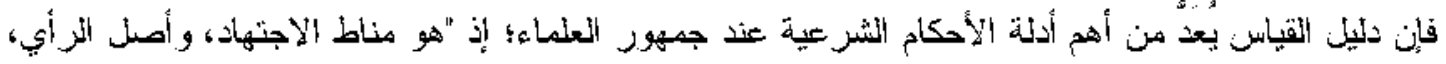

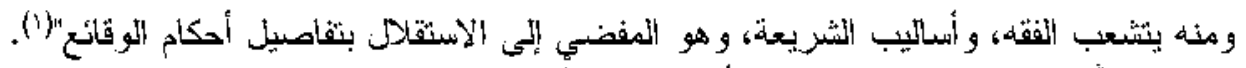

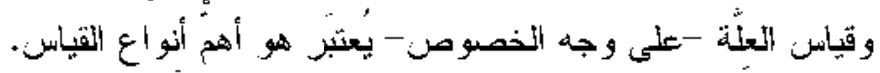

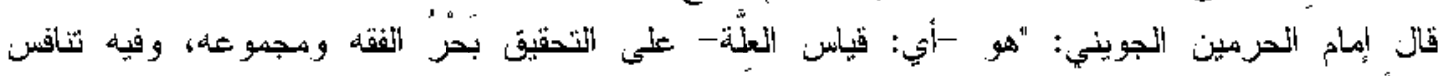

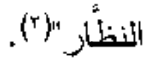

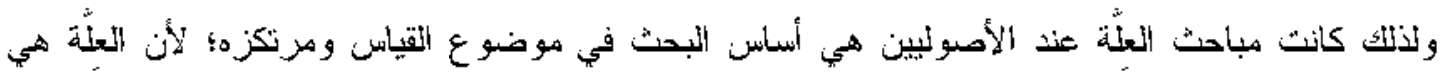
الزركن الأعظم في القياس.

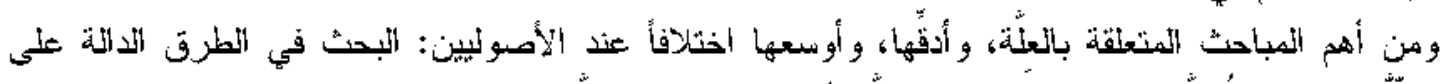

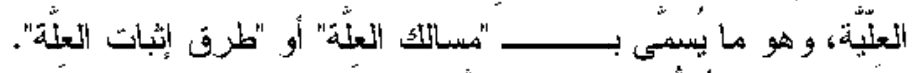

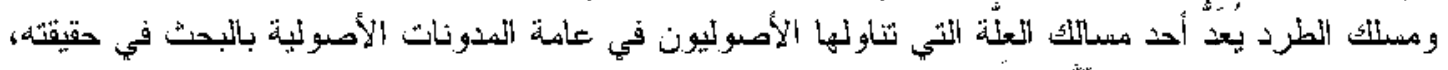

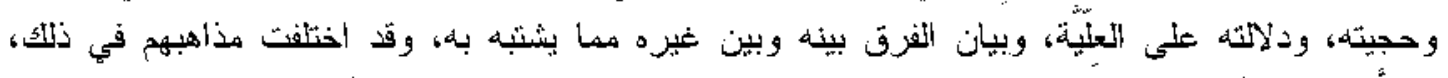

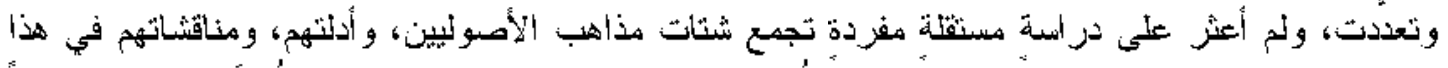

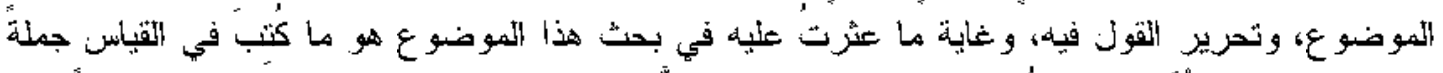

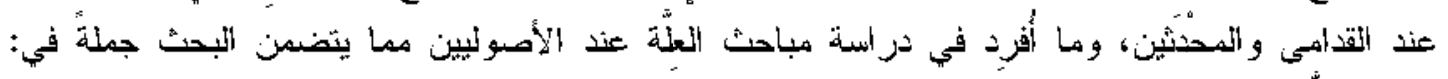

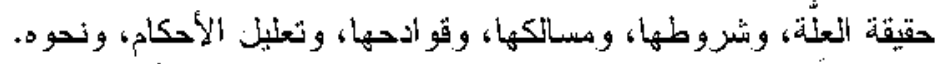

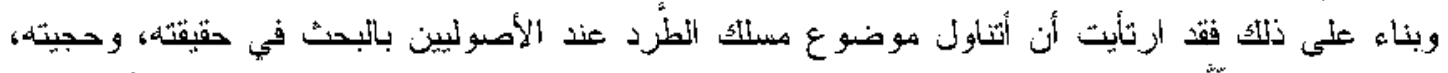

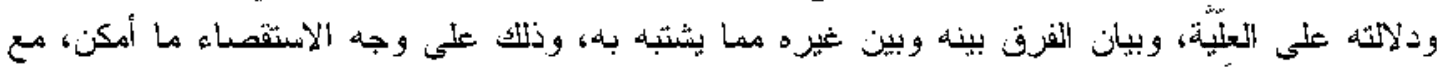

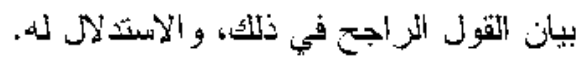




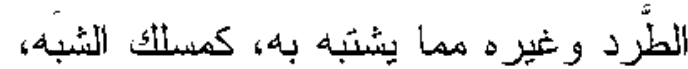
ومسلك الثور انث. اجزاءعات البحث:

1- أستقصاء مذاهب الأصوليين في بيان

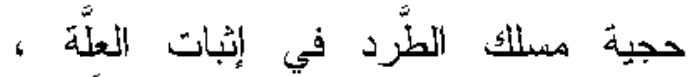

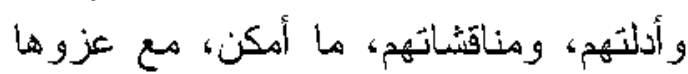

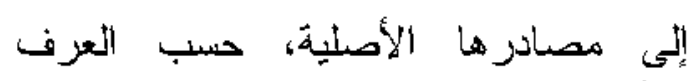

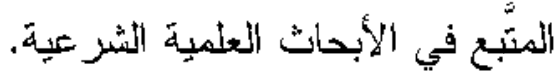
Y- عزو الآيات ببيان أسم السمورة، ورقم الآيةة، في صلب البحث، بعد ذكر الآية

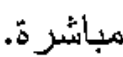
r- عزو الأحاديث والآثار الؤواردة إلىى

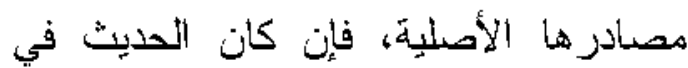
الصحيحين، أو في أحدهما، اكتفيت بتخريجه منهما، و إن لم يكن في أي" منهما عزوته إلىى المصادر الأخرى المعتمدة، ونقلت كلام بعض أهل العلم في بيان در جنها.

ع- توثيق المعاني اللغوية من معاجم اللغة

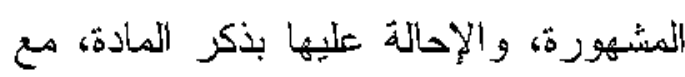
رقم الجزء و الصفحة. - ثذييل البحث بخاتمة أثنملت على أهم النتائج التي نوصست إلبيها في هذا البحث.

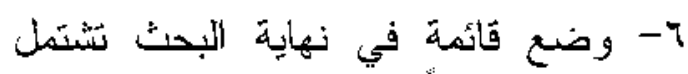

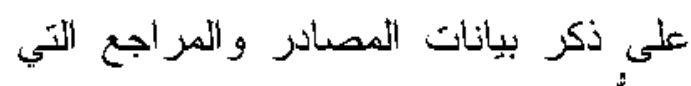
أفذت منها في هذا البّث، ورتزتيها وفق ونت حروف المعجم.

و اللذّ أسئل أن بجعل هذا البحث خالصـاً

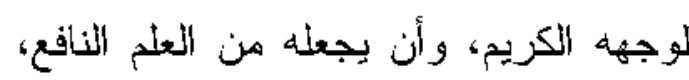

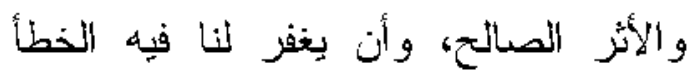

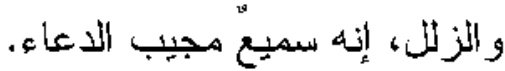

\section{خطة البحث}

وقد الثتملت خطة البحث على تمهيد، وثلاثية مباحث، وخاثتة، مرثبةً على النحو الآثيّي:

التميهيد: وفيه مطلبان: المهن: المططلب الأول: تعريف مسالكك التعلَّة.

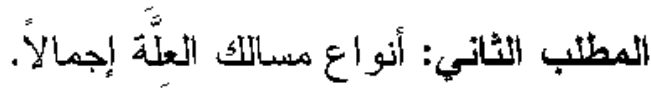

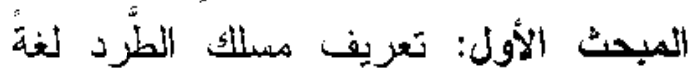

و أصطلاحاً. وفية مطلبان:

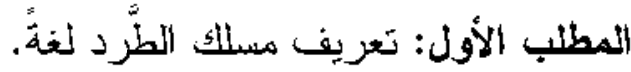

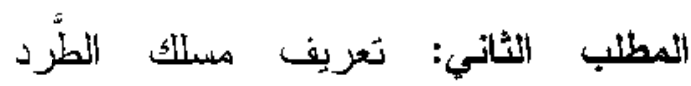
اصطنلاً. المبحث الثاني: بيان أوجه الفرق بين مسلاك الطرّد و غيز ه مما يشتبه به. وفيه مطلبان: المطلب الأول: الفرث بين مسلك الطرّد و الثنبَه. المطلب الثثاني: الففرق بين مسلئ الطُّرد و الدور ان. - مان. المبحث الثالث: حجيّة مسلك الطُّد في الثي إنبات النعلّة. الخاتمة: وتثتنمل على أهم نتائج البحث.

\section{منهج البحث}

المنهج الذي اعتمدت" عليه في هذات البحث هو المنهج التحليلي المقارن، وذلك الكي من خلال جمع وتحليل مذاهب الأصوليبن في بيان حجية مسلك الطرّد في إنبات التعلَّة،

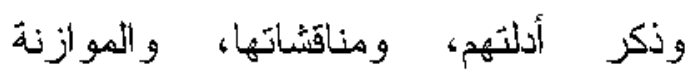

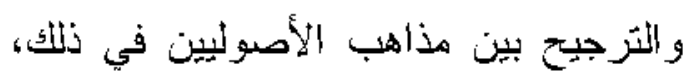

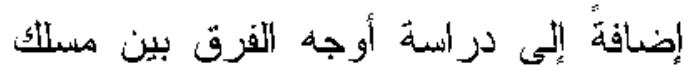


أو كان ذلك على سبيل المجاز، كمسالثك الحق، ومسالتك العلّة.

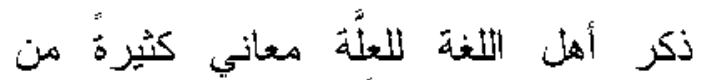

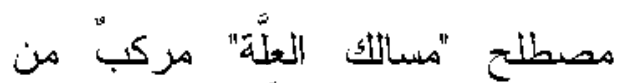
أهمها) (ن) (ن) - المرض، يقال : اعتلّ" فلان" : إذا مزرضن.

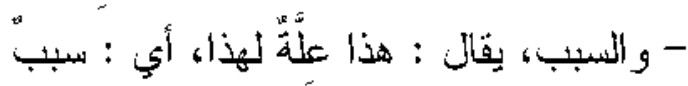
. له

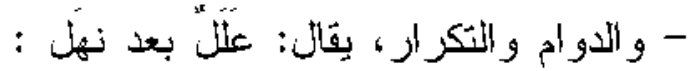

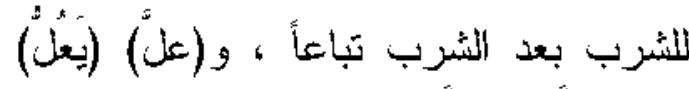

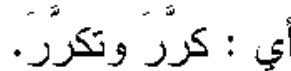

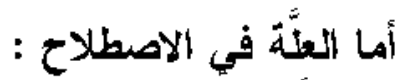

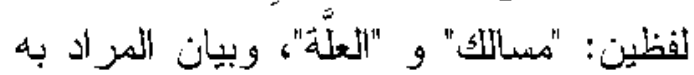

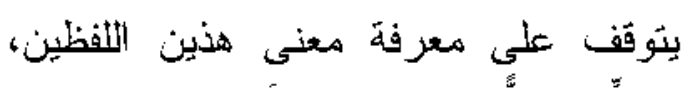

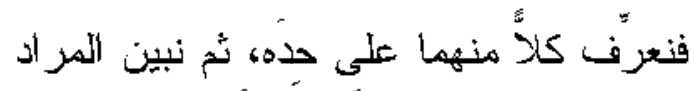

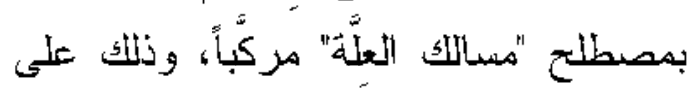
النحو الآتي: أ-تعريف المسالكك:

المسالك: جمع مسنلك، و وأصل مادثه"

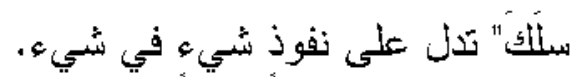

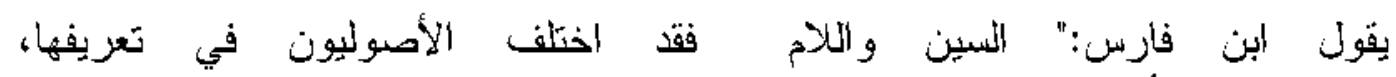
وسأكثفي بذكر أثنهر التعريفات، مع بيان الثتريف المختار منها، وهي على بلى النحو الآتي : التعريف

$$
\text { التعريف الأول : }
$$

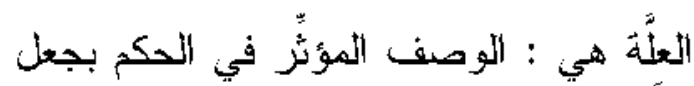

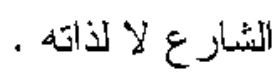

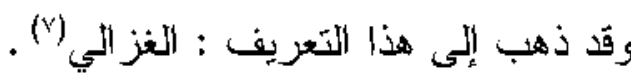

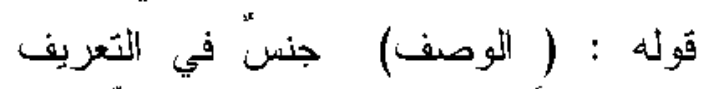

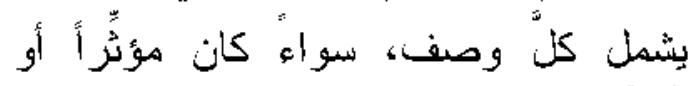
مُعْرِّاً.

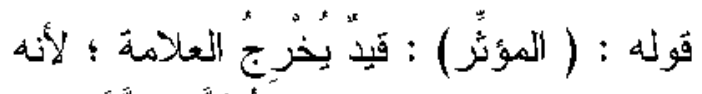

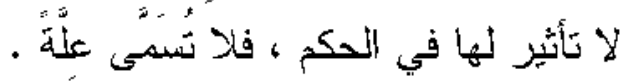

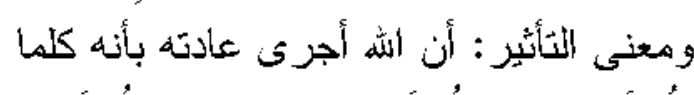

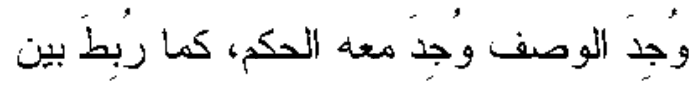

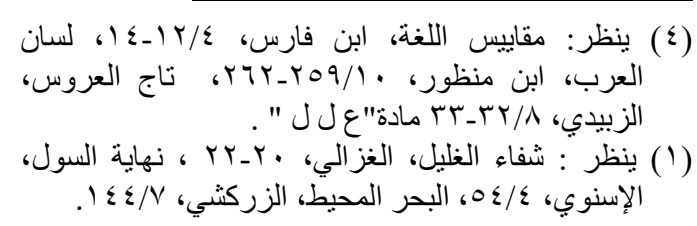

ومنه: مسالتك المباه، أبي: الطرق الثئي

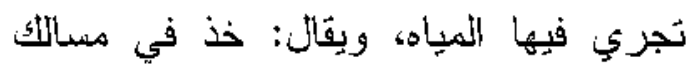

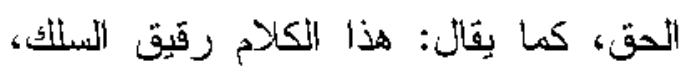

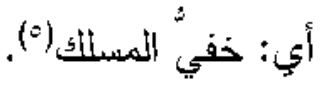

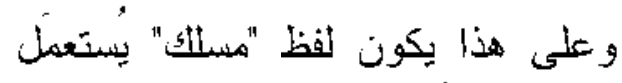

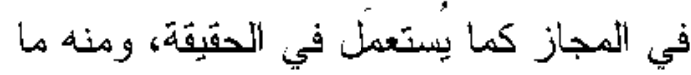

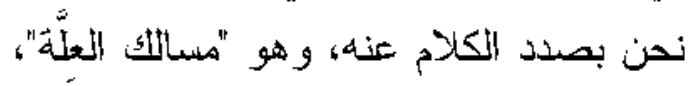
كما سيأتي بيان ذلأك. وبهذا بيضح أن المراد بلفظ "المسلكي"

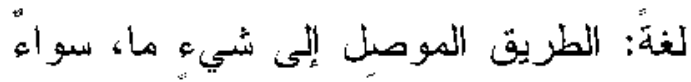
كان ذلك على سبيل الحقيقة، كمسالك المباه،

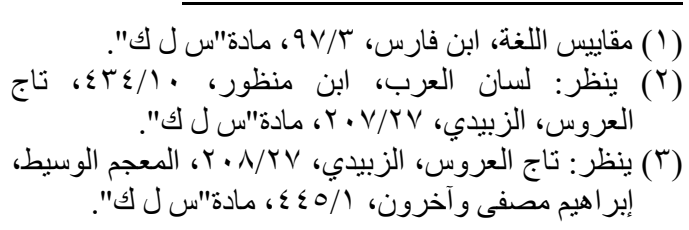




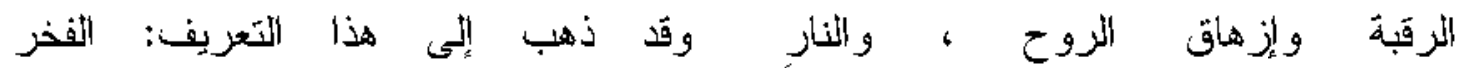
الزرازي|(10)،

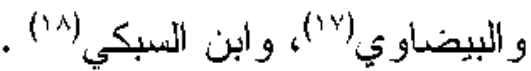

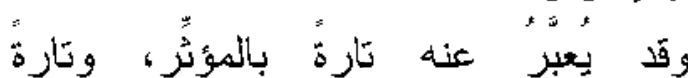

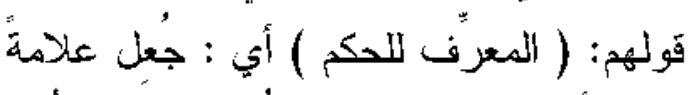
(1) بالموجب

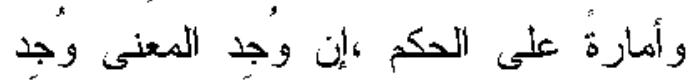
الحكم (19)

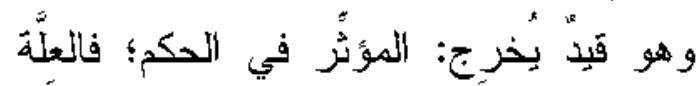

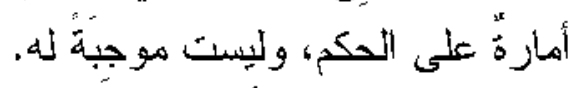

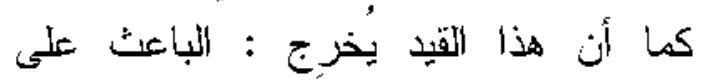

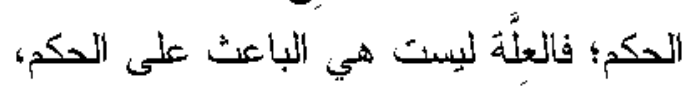
و إنما هي علامةٌّة على وجود الحكم .

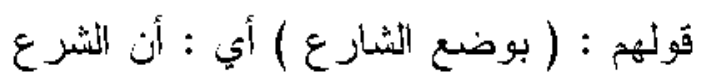

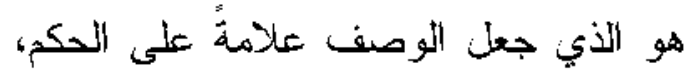
كالإسكار، فإنه كان موجوداً في الخمر ، ولم الم يدل وجوده على تحريمه حتى جعله الثلارع

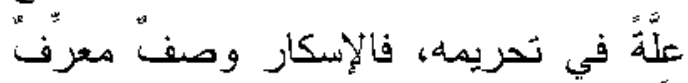
للحكم بوضع الثيارع(r)"

\section{التعريف المختار :} التعريف الأي سأعثمده في بني عند

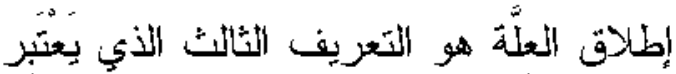

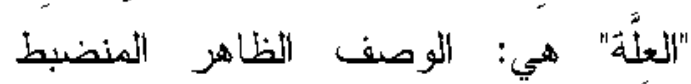

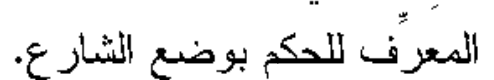
وذلتك لأن الثار ع نُصنَ الأوصاف الظاهرة

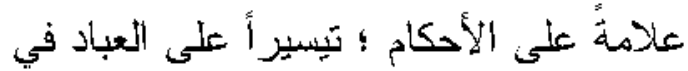

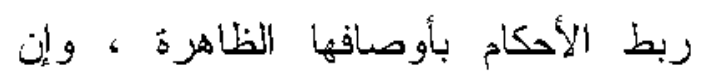

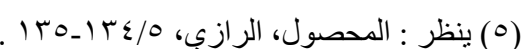

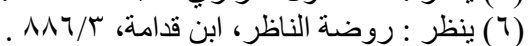

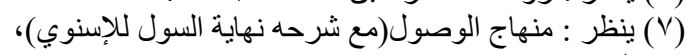

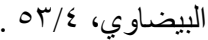

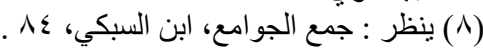

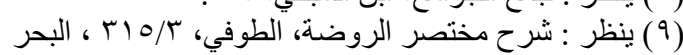

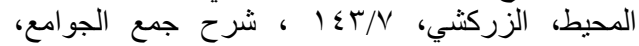

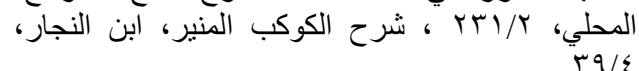
( • (1 ) ينظر : المر اجع السابقة .
ثوله: (بجعزّ الثشارع) : أي أن الثارع هو

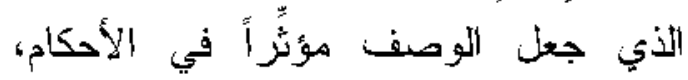

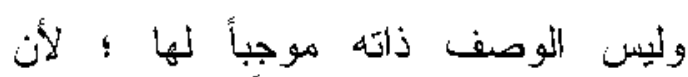

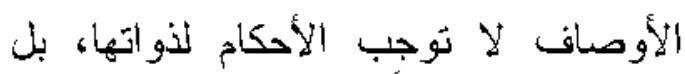

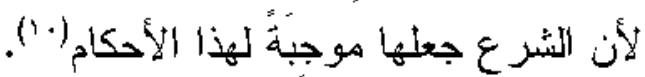
التنعريف الثاني :

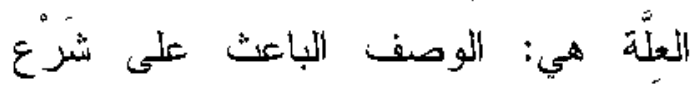
ألخحكم.

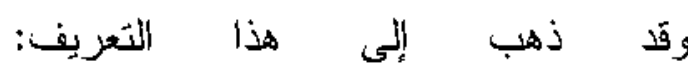
الآمدي"(")" وأبن

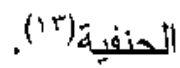

ويقصدون بالباعث : كون الوصف مشتملاك

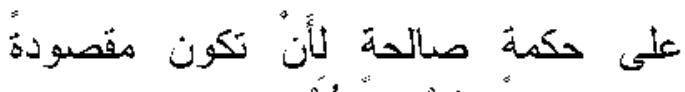
اللثارع من شرع الحكم به، من تحصيل

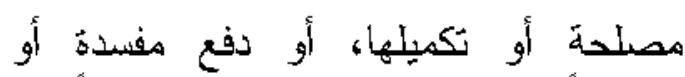
ثقليلهبا (1) التعريف الثالث :

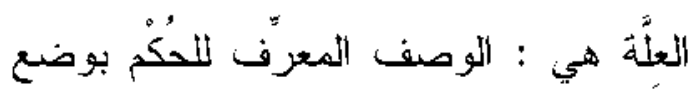

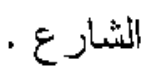

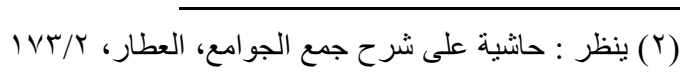
(ץ) ينظر : البحر المحيط، الزركثي،

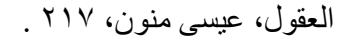

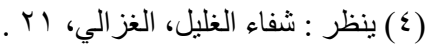

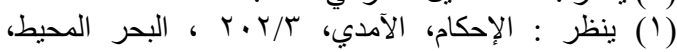

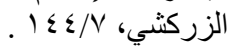

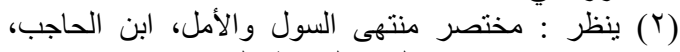
إ

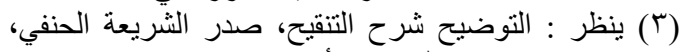

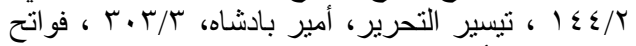

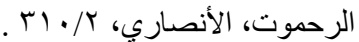

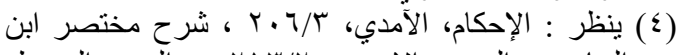

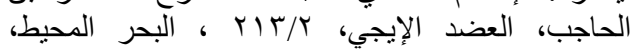

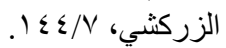




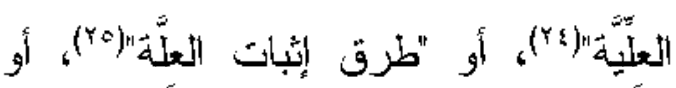

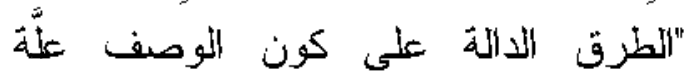

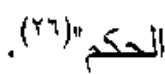

المطلب الثاني: أنواع مسالكك العِّةّة إجمالاً

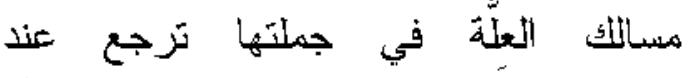
الأصوليين إلى ثلاثة أقسام: النصن، و الإجماع، والأستباط.

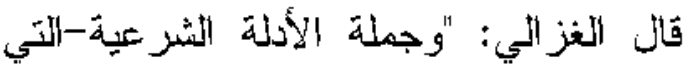

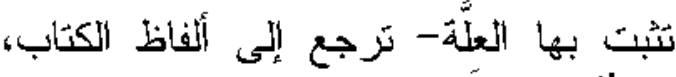

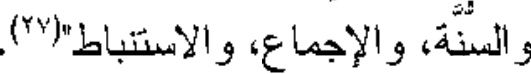

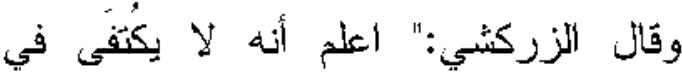

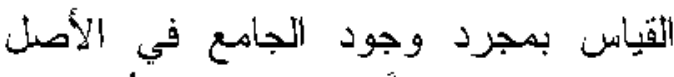

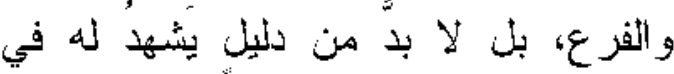

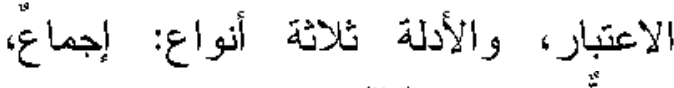

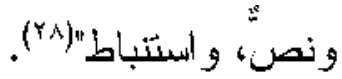

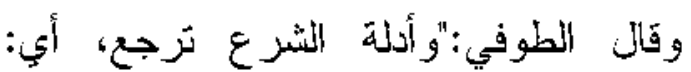

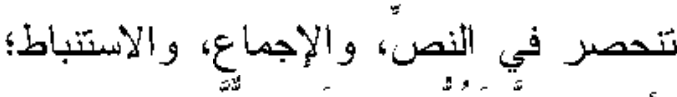

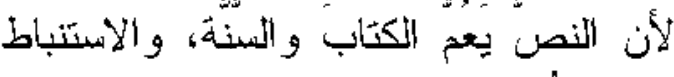

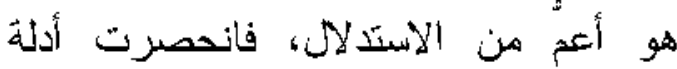

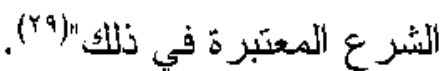
وبعض الأصوليين يلرج الإيماء والتنبيه

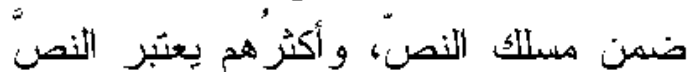
مسلكاً، والإيماء و التنبيه مسلكاً آخر ؛ حيثر النيث اعتبروا أن التعليل في مسلك الإيماء و التنتبيه

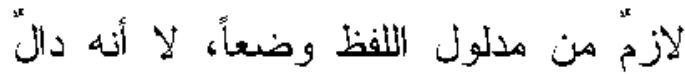
بوضعه على التعليل.

$$
\begin{aligned}
& \text { (ع) ينظر: منهاج الوصول (مع شرحه نهاية السول للإسنوي)، }
\end{aligned}
$$

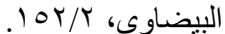

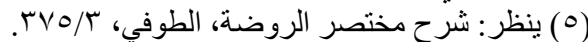

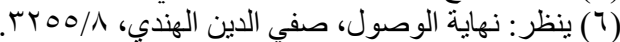

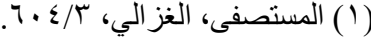

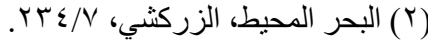

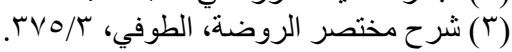

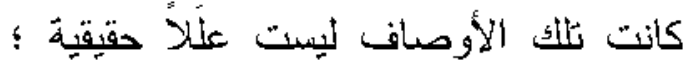

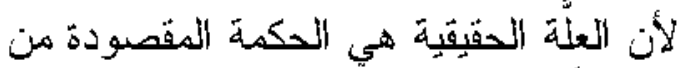

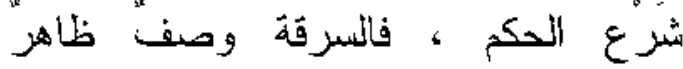

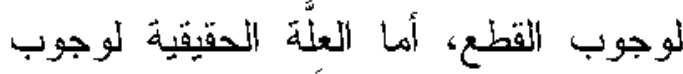
القطع فهي صيانة الأموال، ولكن لما كانت التهل

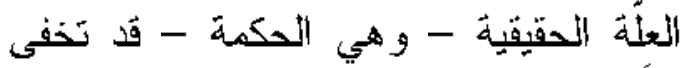

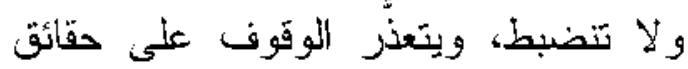
مقاديرها؛ لاختلاف مرانتها الثتي لا نهاية لها بحسب الأشخاص والأزمان والأحوال، لهان

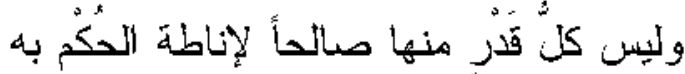

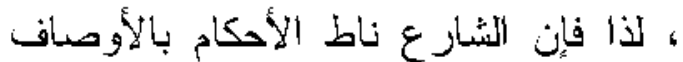

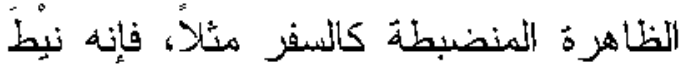

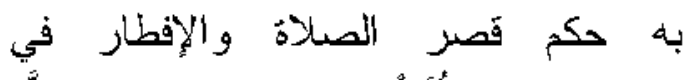

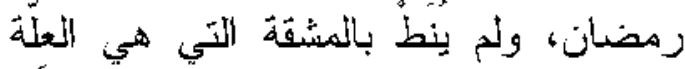

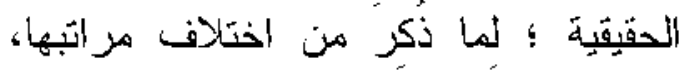
و عدم انضباطهيا (1) وناه وبناء على ما تقدم من نعريف جزئي

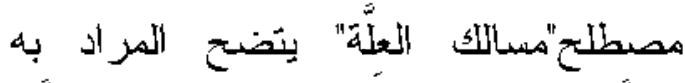

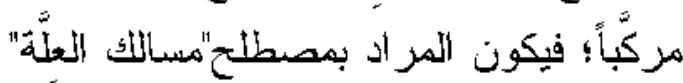

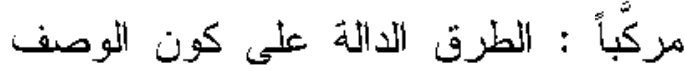

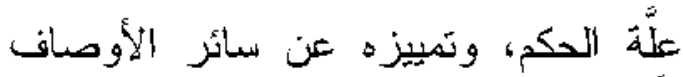
الأخرى(r)

وقد بستعمل بعض' 'الأصوليين تعبيراً آخر

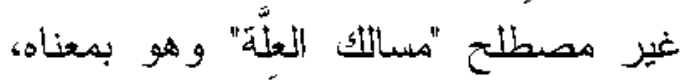

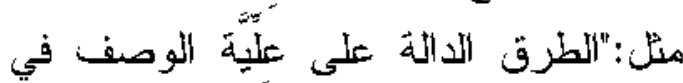

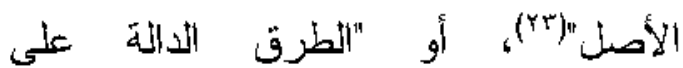

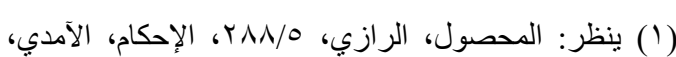

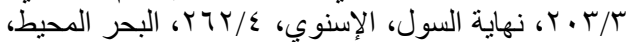

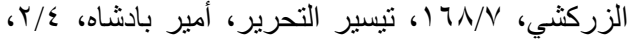

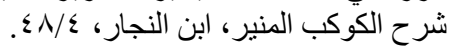

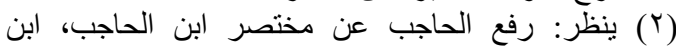

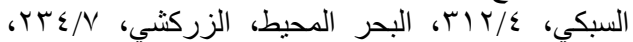

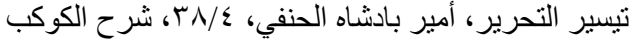

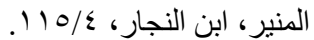

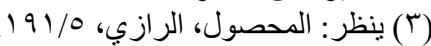




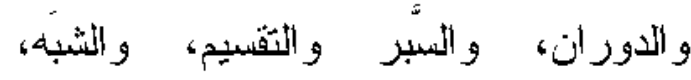

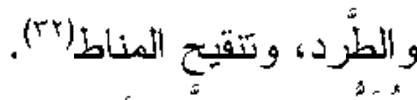

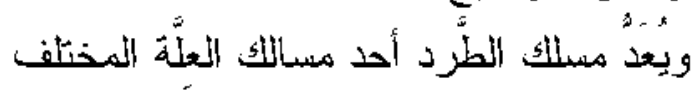

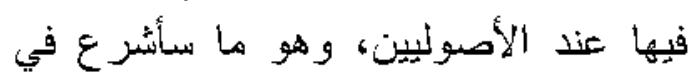

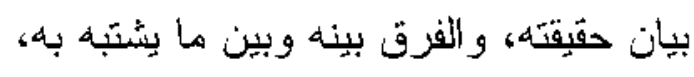

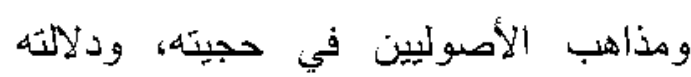

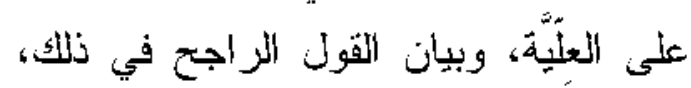
و الأسندلال له.

\section{المبحث الأول}

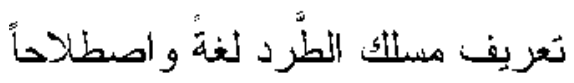
المطب الأول: تعريف مسلك الطُّرد نغةً.

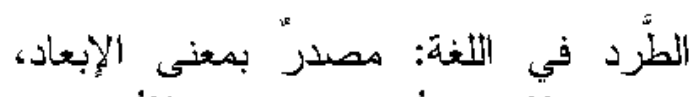
يقال: طردَه بطردهُ طرداً، أي: أبعدهُ.

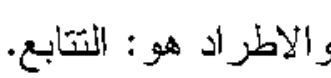

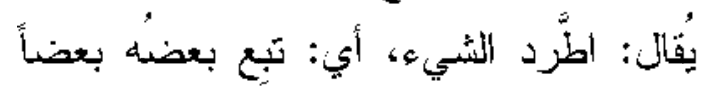

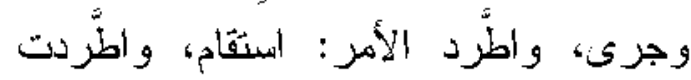

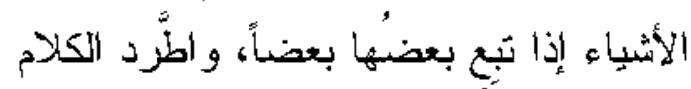

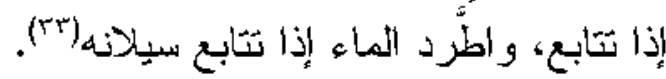

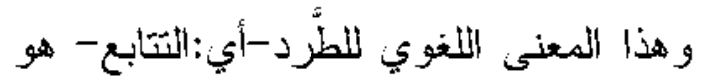

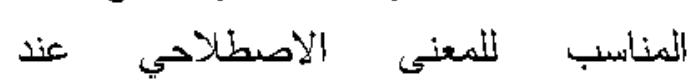
الأصوليين كما سيأتي بيانه؛ ولذلك تالت

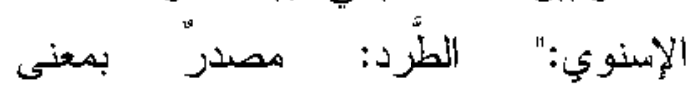

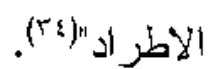

المطلب الثاني: تعريف مستلك الطُّرد اصطلاحاً. اختلفت عبارات الأصوليون في نعريف الطُّرد اصطلاحاً، وذلك على النحو الآتي: التعريف الأول:
قال الطوفي:و"والفرق بيذه-أبي: الإيماء-

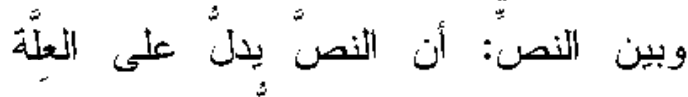
بوصفه لها، والإيماء بدل بليها بطريق انيق

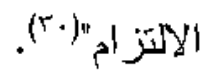

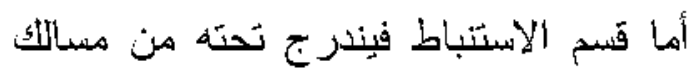

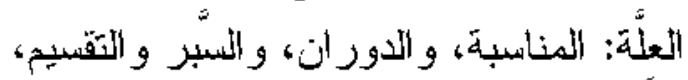

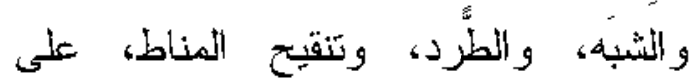

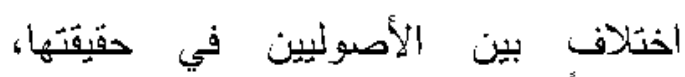

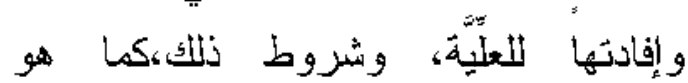
مبسوطٌ في مدونات الأصوليين. وإذا ثبث أن مسلكاً من هذه المسالتك يفيد

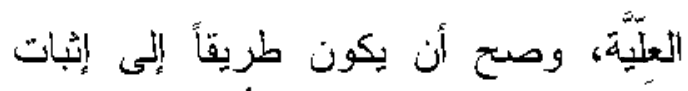

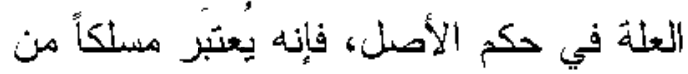

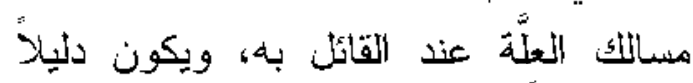
تطيها بمفرده.

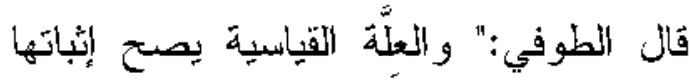

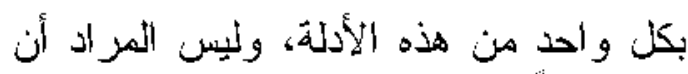

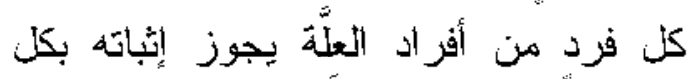

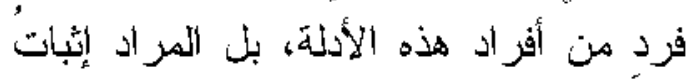

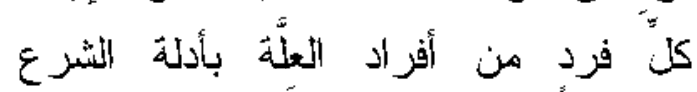

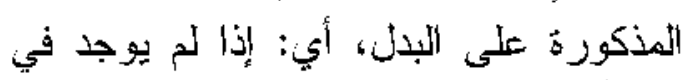

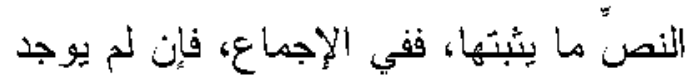

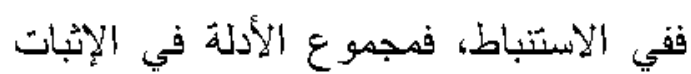
مقابل" لمجموع العلل "(r).

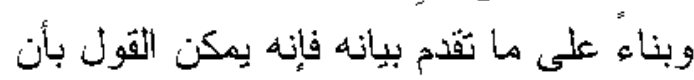

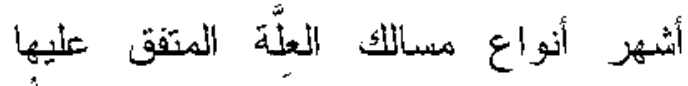

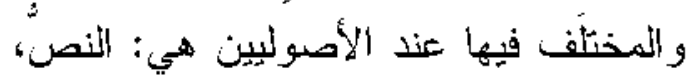
والإيماء و التتبية، و الإجماع، و المناسبة،

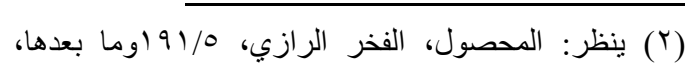

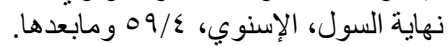

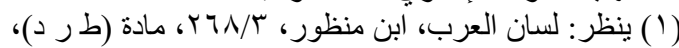

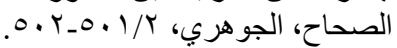

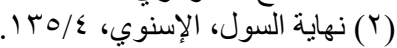


وقد خرج بالاقتصار على ثبوت الحكم في

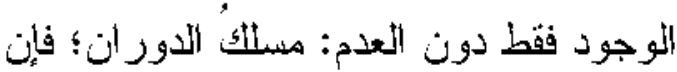

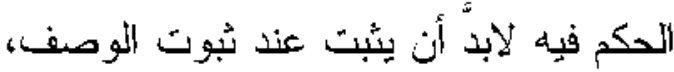

وينتفي عند انتفائه.

كو معرفه بعضهم بأنه: افتزر ان الحكم بسائر

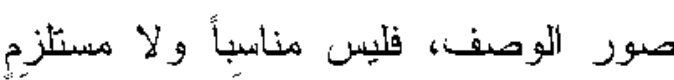

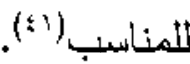
فال القزر افي:" لأنه منى كان مناسباً كان ذلتك

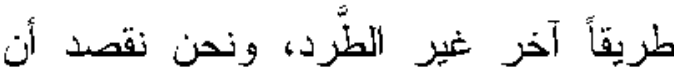
نثبت طريقاً آخر غير المناسبة، وكذلك لانيل

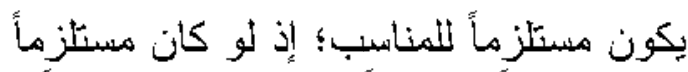

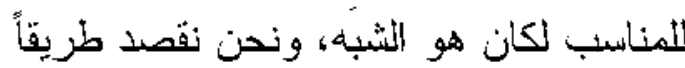

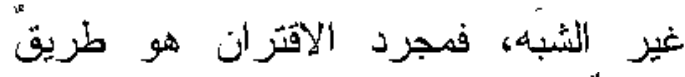

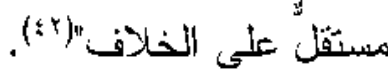

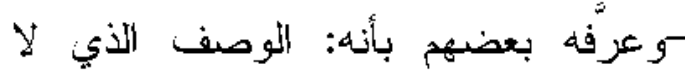

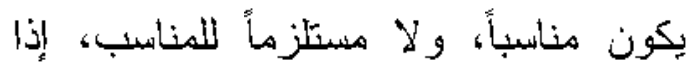

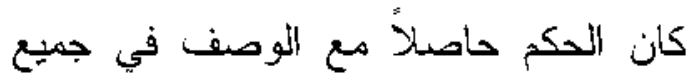

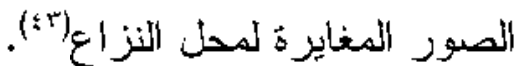

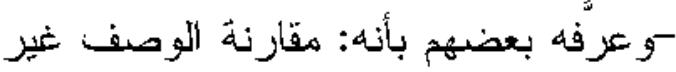

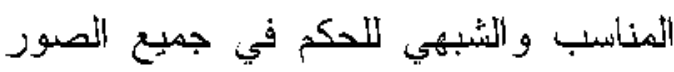

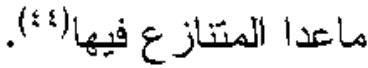

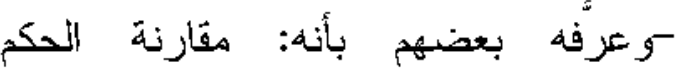
للأوصف من غير مناسبة (ه)؛

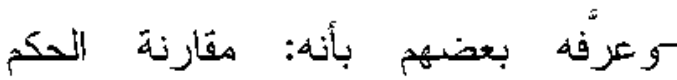

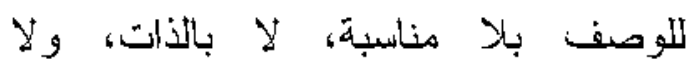
بالثَّبع (")

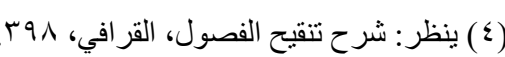

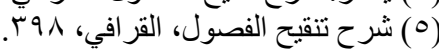

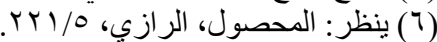

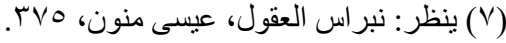

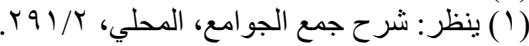

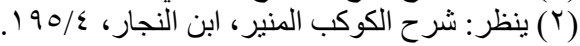

هو: أن يشبت الحكم مع الوصف الذي لم

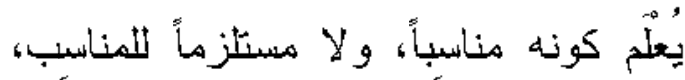

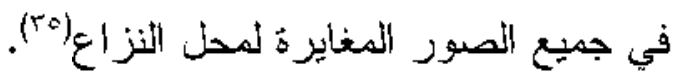

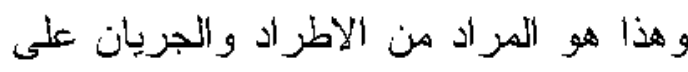
قول الأكثر (ri).

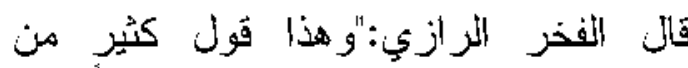
قدماء فقهائنا"(rV) وعبر بعضه عن هذا التعريف بعبارات

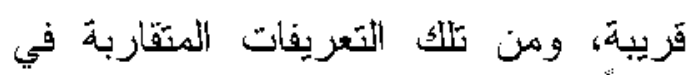
المعنى ما يأتي: ونئ

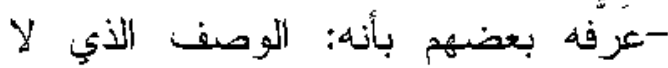

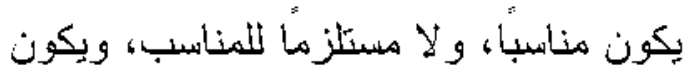

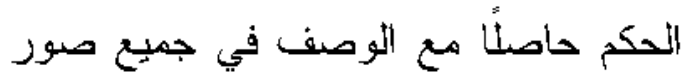

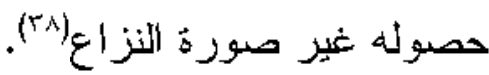
فقولهم:(الوصف الذي لم يعلم كونه مناسبا)

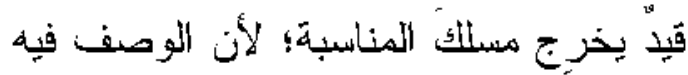
يُعلَّم كونه مناسباً. وقونهم:(في جميع الصور المغايرة لمحل النزاع) أي: في جميع الصور يشبت الحكم مع الأوصف ماعدا الصورة المتناز ع فيها.

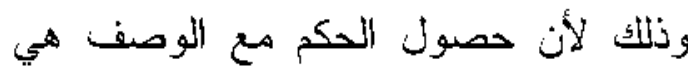

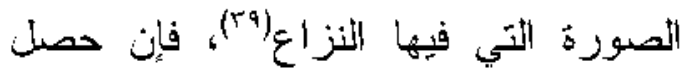
الحكم مع التوصف في صورة النزاع كان

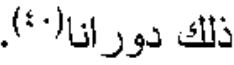

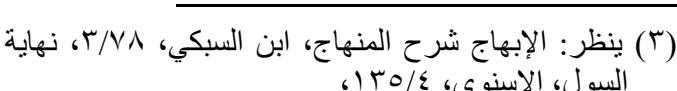

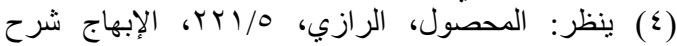

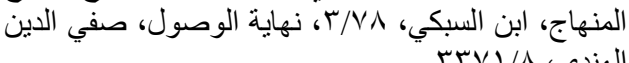

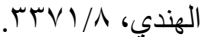

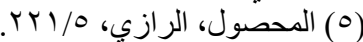

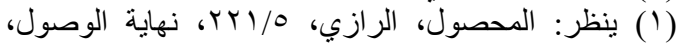

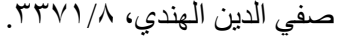

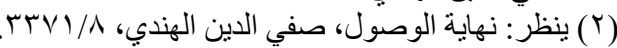

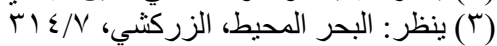


تعليق الحكم بما لا ينانِب الحكم، و لا بِشْعِر

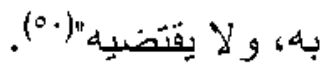
التعريف الثأث: الطُّرد هو : الوصف الأي لا يناسب الحكم،

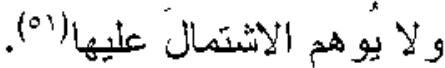

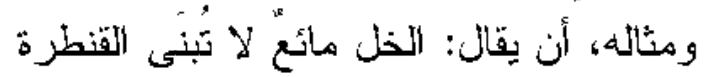
على جنسة، فلا يزيل النجانية كالدهن،

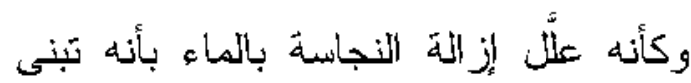
القنطرة على جنسه واحترز من الماء

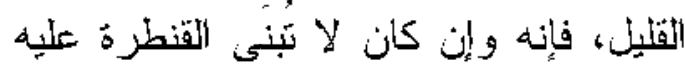

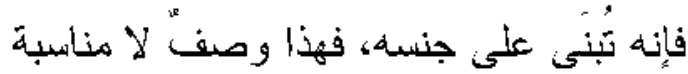

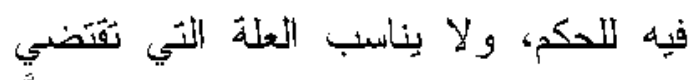
الحكم بالنضمن لها والاشتمال عليها، فإنًا نعلم أن الماء جعل مزيلاً للنجاسة لخاصِيّة

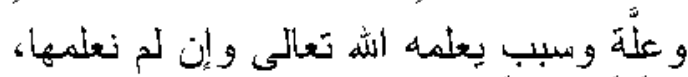

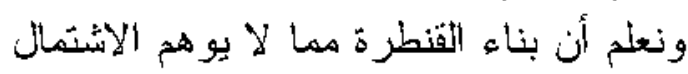

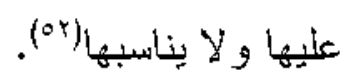
التعزيف الترابع: الطُّرد هو : وجود الحكم عند وجود التوصف التون

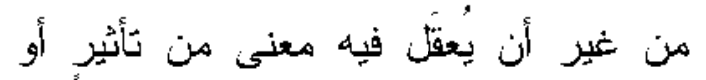
إخانة(r) منئ.

\section{التتعريف الخخامس:}

هو : حمل الفرع على الأصل بغير أوصاف

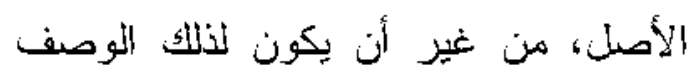

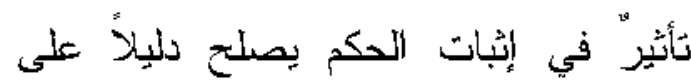

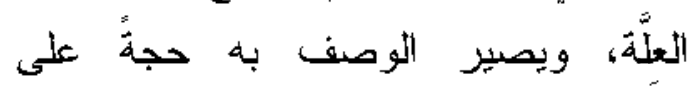
التغير (o؛)

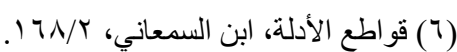

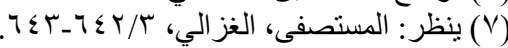

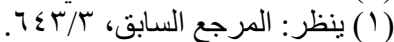

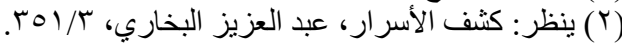

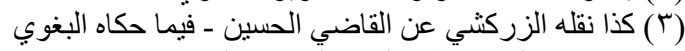

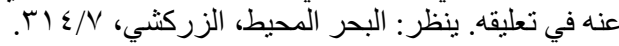

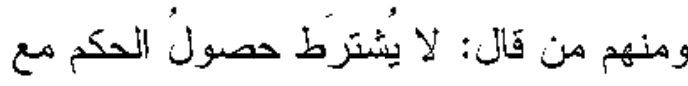
الوصف في جميع الصور، بل يكفي في

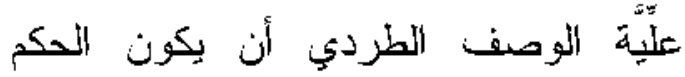

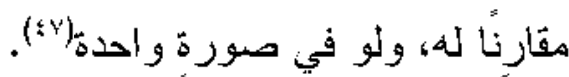

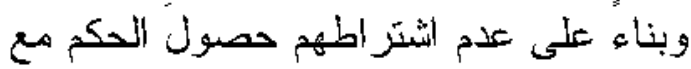
الوصف في جميع الصور يكون المبراد

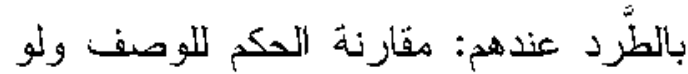
في صورة واحدة، وهذا معنى أعمّ للطرد

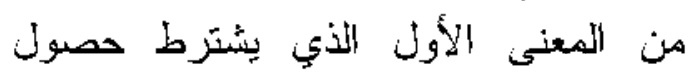

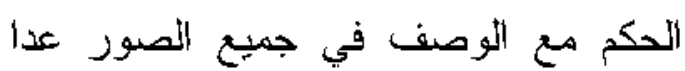
الصورة المتناز ع فيها، وستأتي مناقثية هذا القول في بيان حجية مسلك الطرد بعون الهل تعالّى. التعزيف التثاتي:

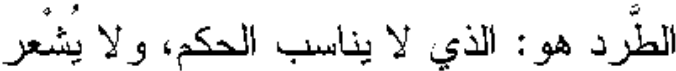
بـ ثال الجويني:" الطُّرد هو : الذي لا لإناسب

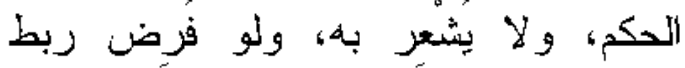

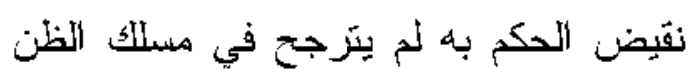
قبل البحث عن قوادح النفي على الإثبات،

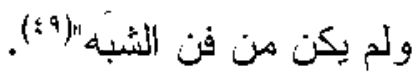
و هذا التعريف فريب في في معناه من التعريف الأول، غيز أنه لذ يصرح بحصول التحكم معه في جميع الصصور المغايرة لمحل النزز اع.

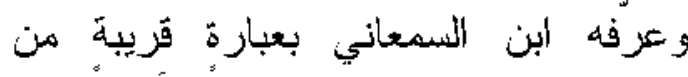
عبارة إمام الحرمين الجويني، فعرفّه بأنه: "

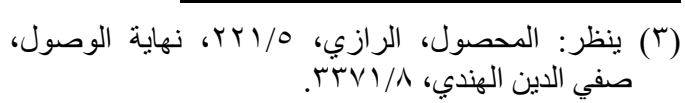

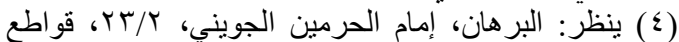

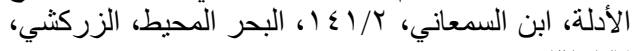
T الأن/

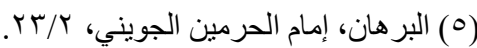


تعند ثأمل التعريفات التي تقدم ذكرها لمسلك

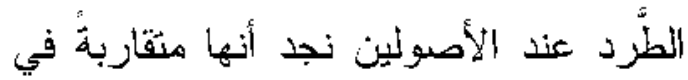

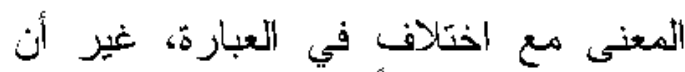

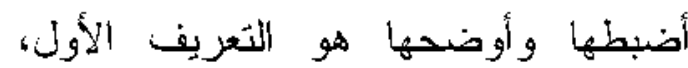
وهو أن النطّرد:

مثارنة التوصف غير الطرد: المناسب و الثبهي للحكم في جميع الصور ماعدا المتنازع فيها.

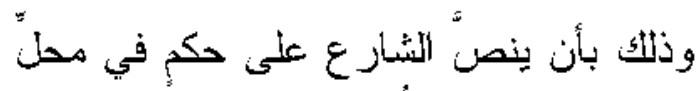

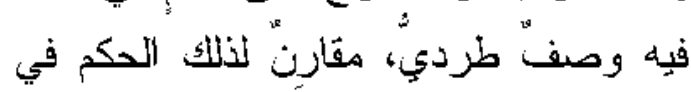

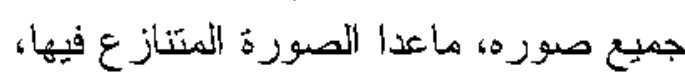

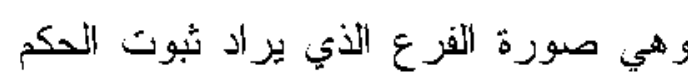

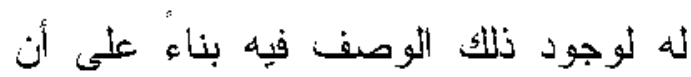

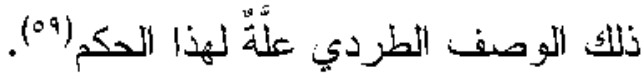

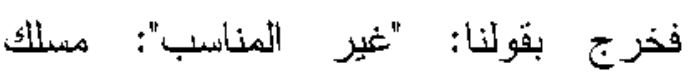
المناسبة (3.).

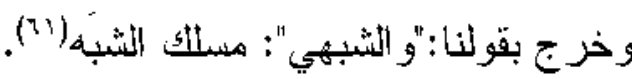
وخرج بالاقتصار على المقارنة في الوجود: وخدئ

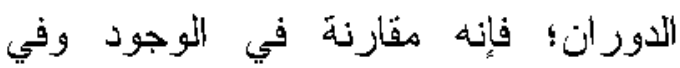
العدم، وقد يكون الوصف في الدوران

مناسباً (ir).

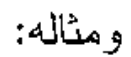
قول بعضهم في إزالة النجاسة بنحو الخل:

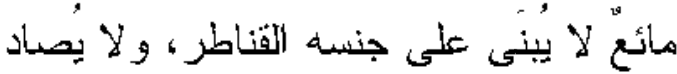

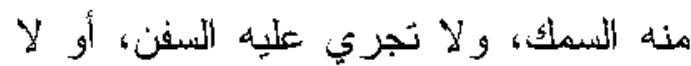

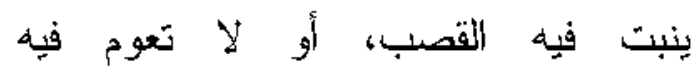

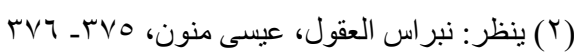

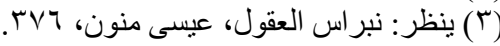

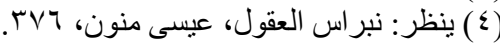

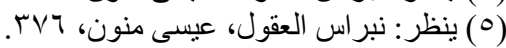

ومثاله أن يقال في نية الوضوء: عبادةٌ

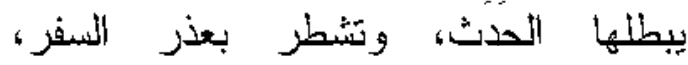

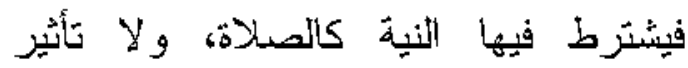
اللثطر بعذر المفر في إنبات النية، وكقول

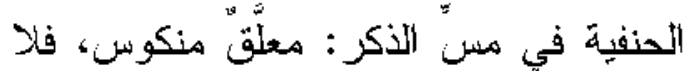

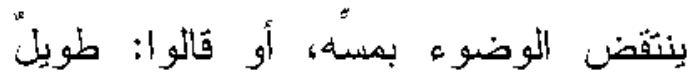

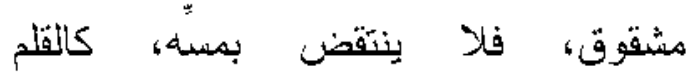

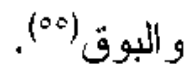

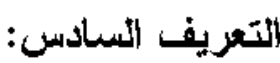
الجمع بين الأصل و الثقر ع بوصف بُعلَّ خلوه

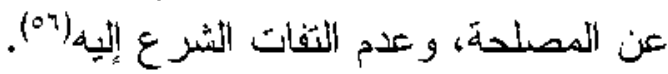

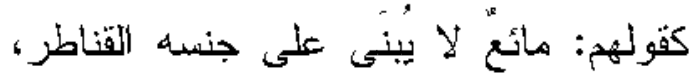

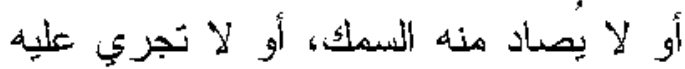

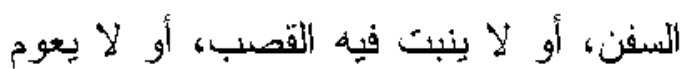

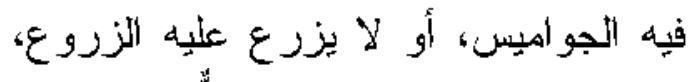

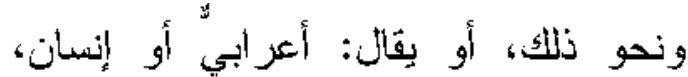

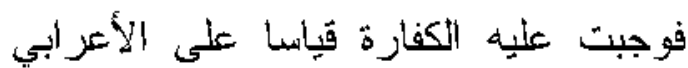

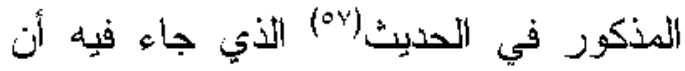

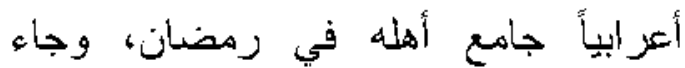
يضرب صدره وينتف شُعره - كما في بعض الزروايات - ويقول: هلكت و وأهلكت، واقعت أهلي في نهار رمضان ، فقال له إنهات

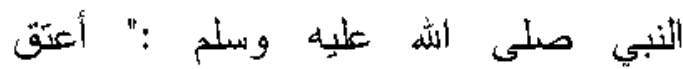

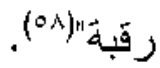
التعريف التراجح: - ابت

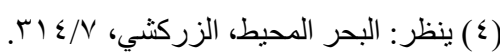

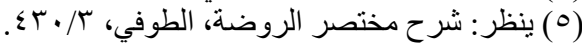

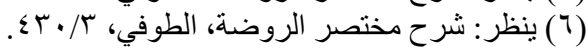

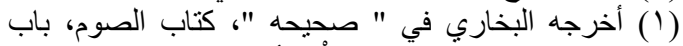

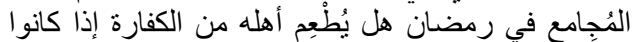

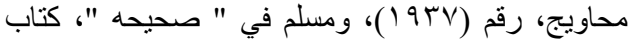

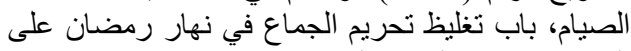
الصائم ووجوب باب تلطيطارة الكبرى فيه. 
فظهر أن الحكم بدور مع التوصف في

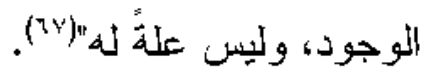

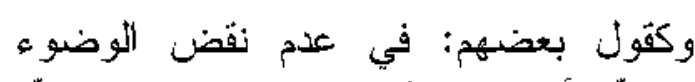

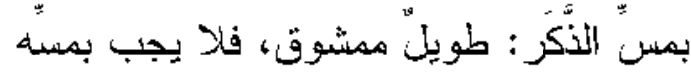
الوضو ء كالبوق (ㅅ)

وكقول بعضهم في طهارة الكلب: حيوان" مألون، له شعر "كالصوف، فكان طاهرا"،

$$
\text { كالخروف)(r9). }
$$

\section{الثمبحث الثاني}

بيان أوجه الفرث بين مسلك الطُّرد و غيلره

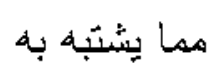
المطلب الأول: الفرق بين مسلثك النّرد والثشبَه.

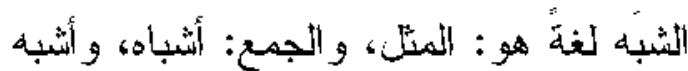

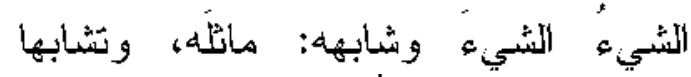

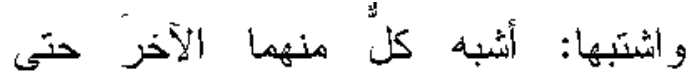
التبسيا( (v)

و اصطلاحاً هو: الوصف المقارن للحكم الذي لا تظهر فيه المناسبة بعد البحث التام،

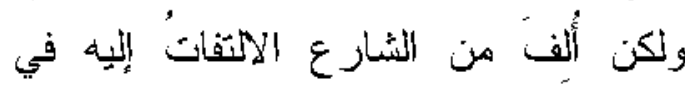
بعض الأحكام (M) من ومثاله أن يقال : في مسألة إز الذة النجاسية أنها

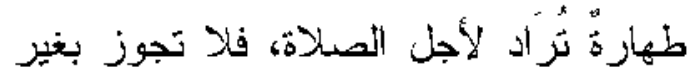

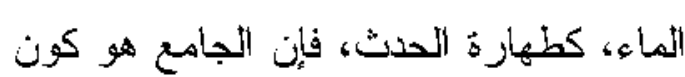

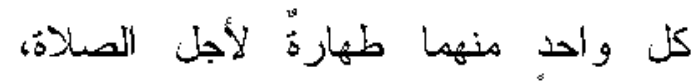

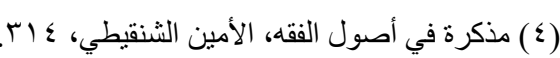

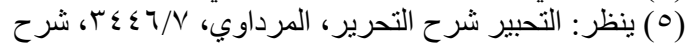

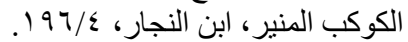

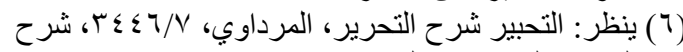

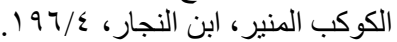

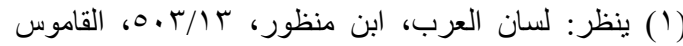

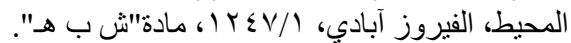

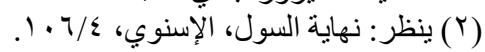

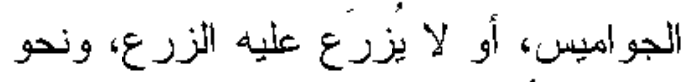

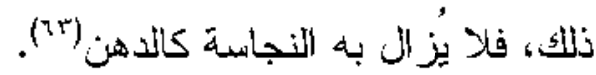
فالّوصف وهو عدم بناء القنطرة على جنسه بهـ

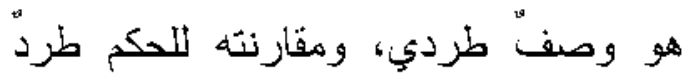

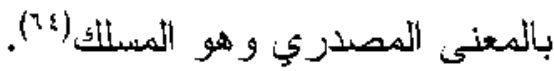
قال المحلي: "فبناء القنطرة و عدمه لأل مناسبة

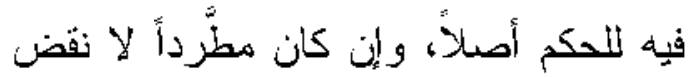
تلبيه")(30).

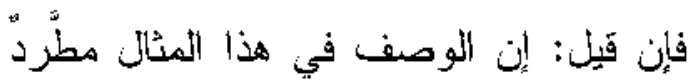

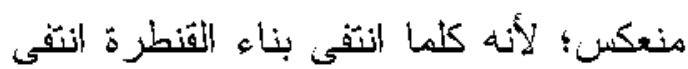
إز الذة النجاسية، وكلما وجدت وجدت، فلهيه الذوران دون الطرد، فالجواب: أن المعنبر وجناب في الدوران الاطر اد و الانعكاس في الثثيء الو احد، كالخمر إذا لار صار خلاً، فكذلك المعتبر في الطظرد، وهو الاطر اد في الثيء الذي لا تبنَى على جنسه القنطرة كالدهن، وعدم الانعكاس فيه بأن يكون إذاذ بُني عليهيها

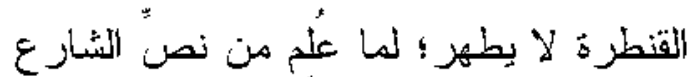

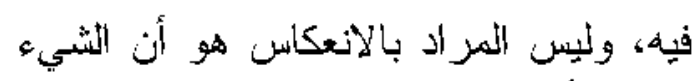

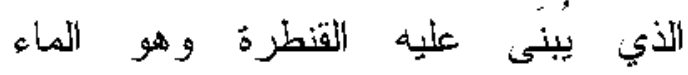
يطهر (77) قال الأمين الثشنيطي:" ومعلوم أن كونه

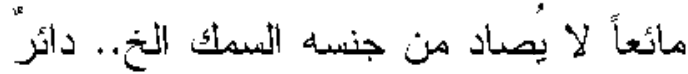
معه الحكم الذي هو عدم الطهارة، ميع أنها

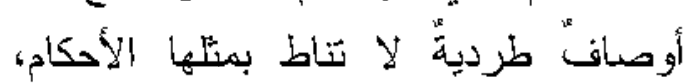

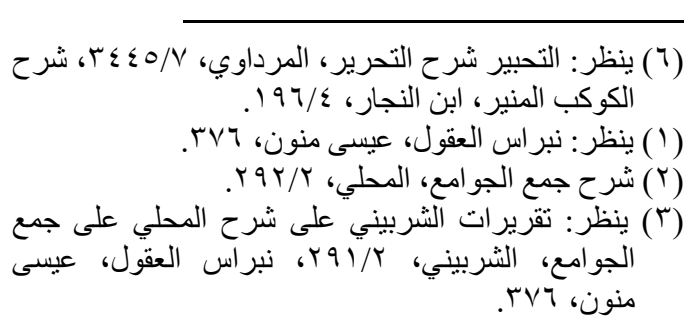


الطردي ما لا بناسب الحكم، ولا يُظَن أثتماله على الحكمة المقتضية للحكم.

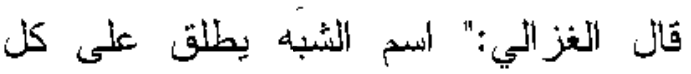

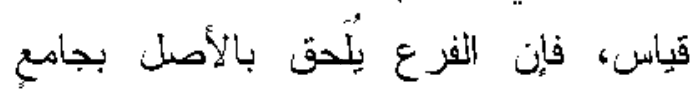

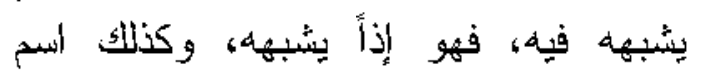

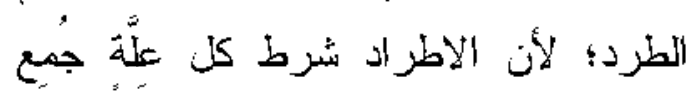

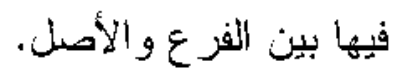

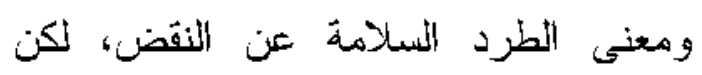
العلًّّة الجامعة إن كانت هؤثرةً أو مناسبةً

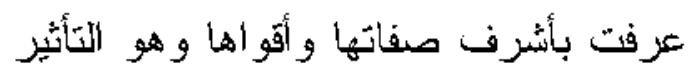

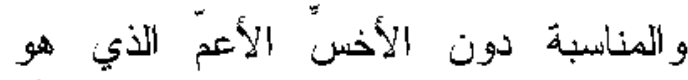

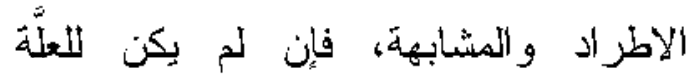

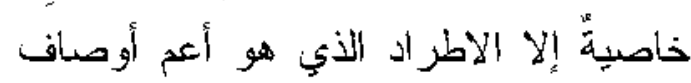

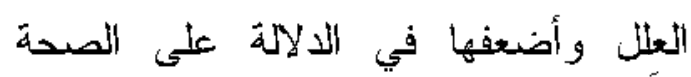

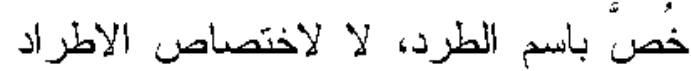

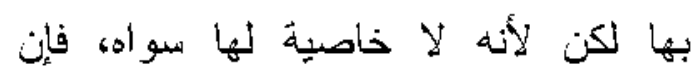

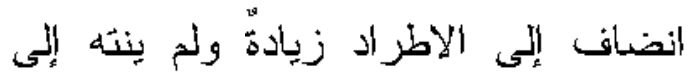

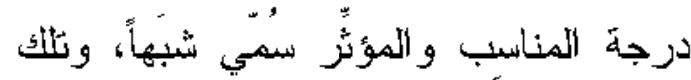

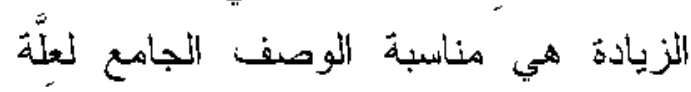

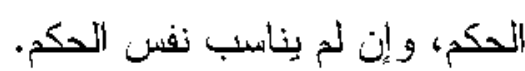

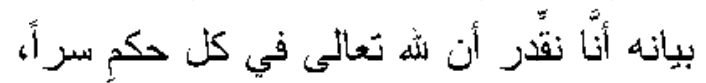

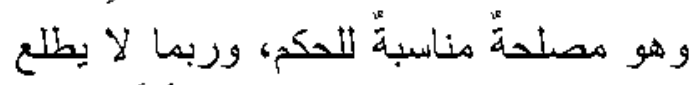

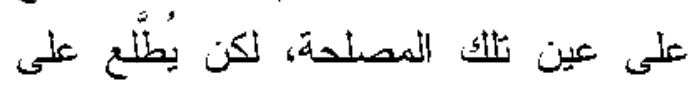

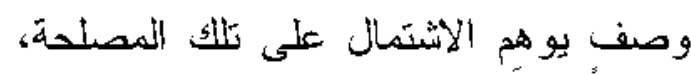
ويظن أنه مظنتها، وقالتها الذبي بتضئنها

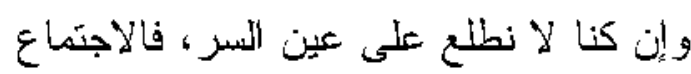

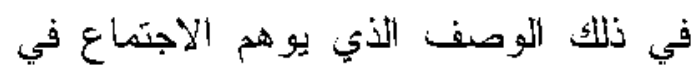

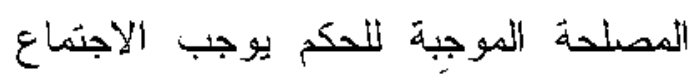
في الحكم. ويتميز عن المناسب بأن المناسب هو الذي لئي يناسب الحكم ويتقاضاه بنفسه، كمناسبة

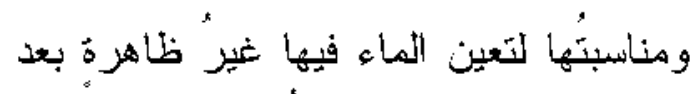

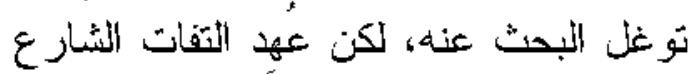

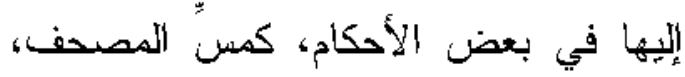

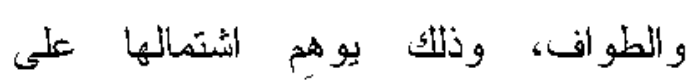
المناسبة)(بr).

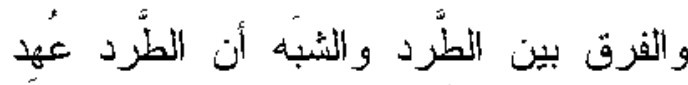

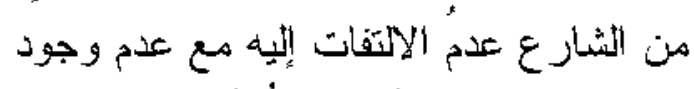

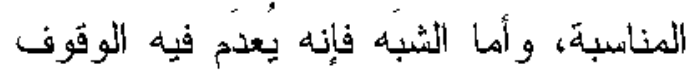

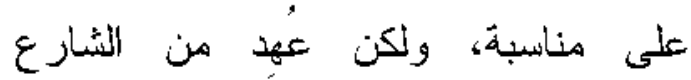
الإعتبار له في بعض الأمور.

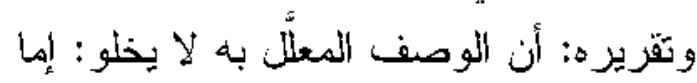
أن تظهر فيه المناسبة، أو لا تظهر ، فالأول:

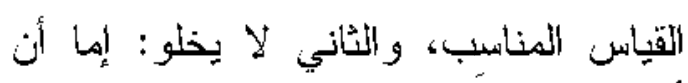

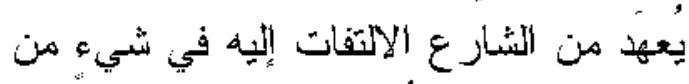

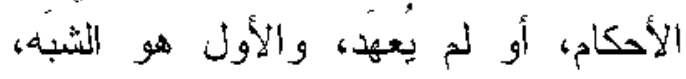

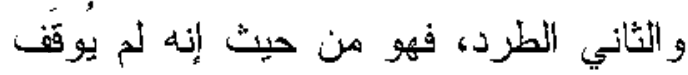

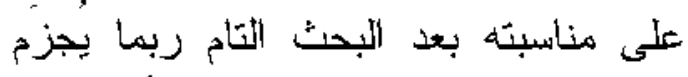

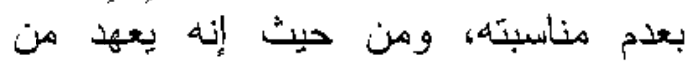

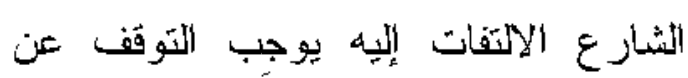

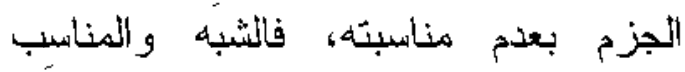
يشتركان في كون كل واحد منهما غير ونير مجزوم بعدم مناسبتها، و والثبه و والطرد

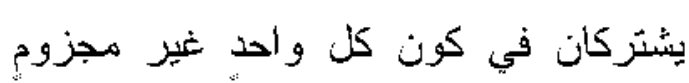
بالمناسبة، فهو مرتبة بين المناسب و والطرد،

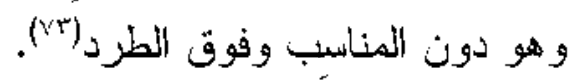

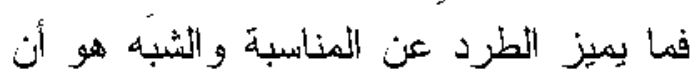

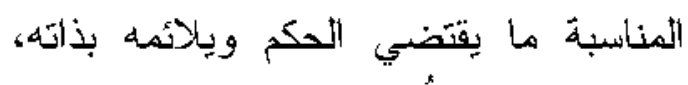
وأن الثبه ها يُظن الشتساله على الحكمة

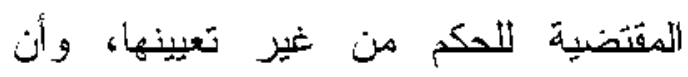

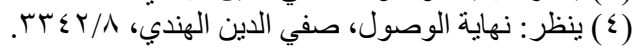


بنفسه، فيمس" المقصود على وجه المناسبة،

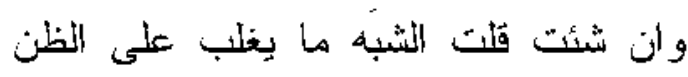

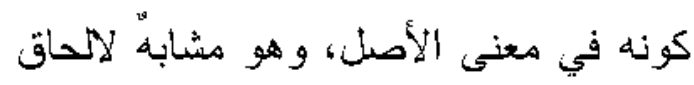

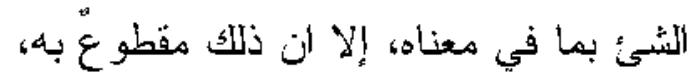

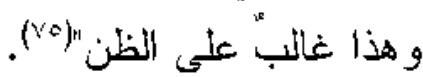
وقال ابن السمعاني في بيان الفرق بين قياس

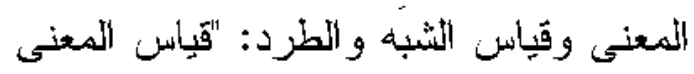

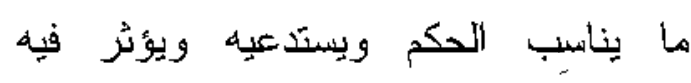

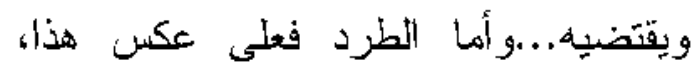

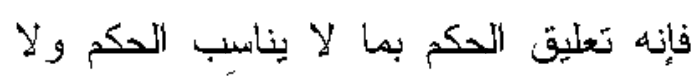

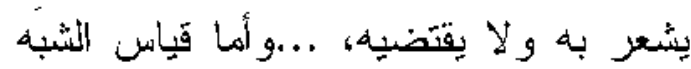

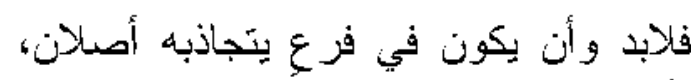

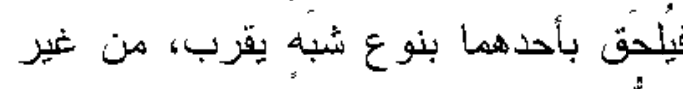

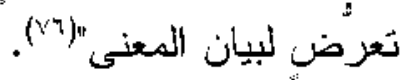

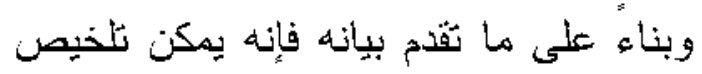

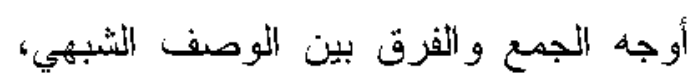

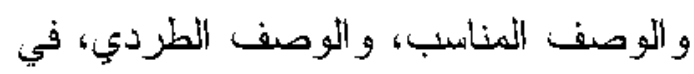
الآتي:

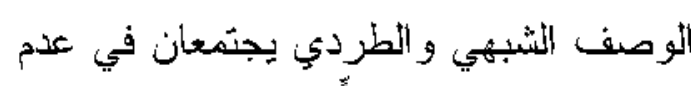

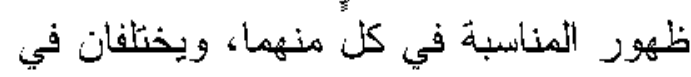

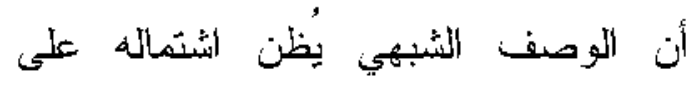

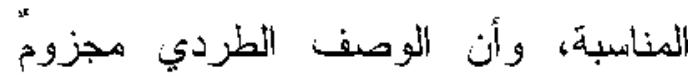
بانتفاء مناسبته، أما الوصف الوصنف المناسب فهو

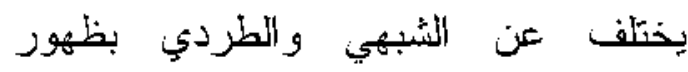
مناسبته و اقتضاء الحكم بنفسه. المطلب الثاني: الفرق بين مسلك الطُّرد و الاوران.
الثَّدّة للتحريج، ويتميز عن الطزرد بأن الطرد لا يناسب الحكم ولا المصلحة المبهمة الموجبة للحكم، بل نعلم أن ذلك الجنس لا لا لأل يكون مظنة المصالح وقالبها، كقول القائل:

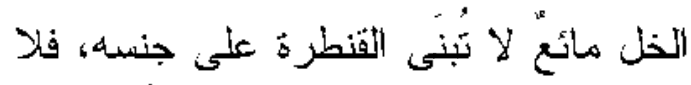

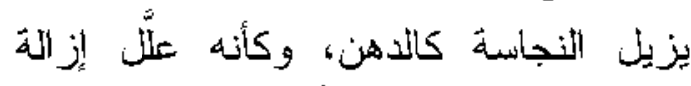

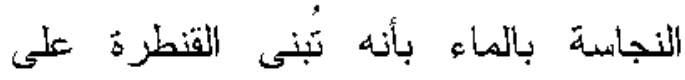

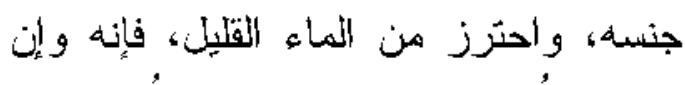

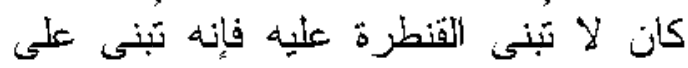

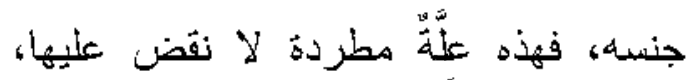
ليس فيها خصلة سوى الاطر اد.

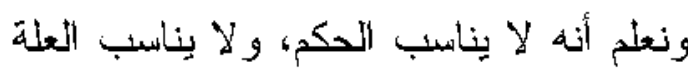
الثي تقتضي الحكم بالتضمن لها والاشتمال

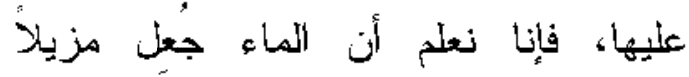

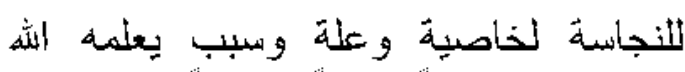
تعالى وإن لم نعلمها، ونعلم أن بناء القنطرة

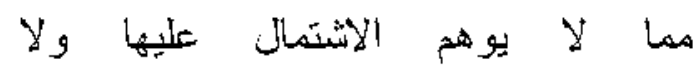
يناسبها"(s) وقال أيضاً: "وعقدُ الباب تمييز' الثُبَه عن

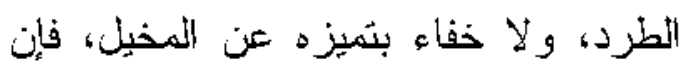

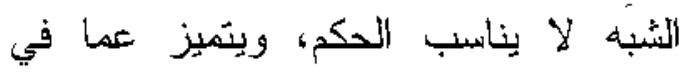

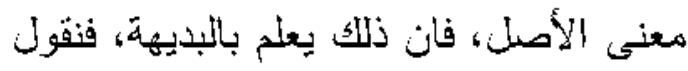

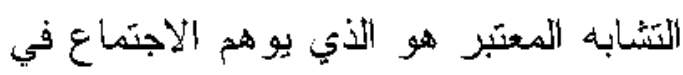
مخيل يناسب الحكم المطلوب، وذلك المخيل

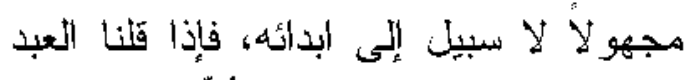

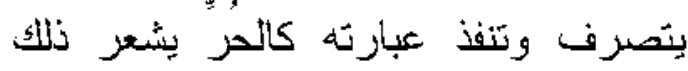

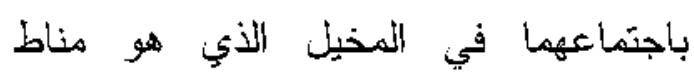

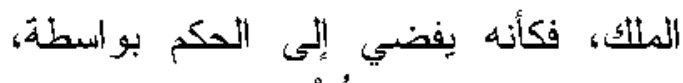
و الطرد هو الذٔي لا بُشْغر بالحكم لا بنفسه

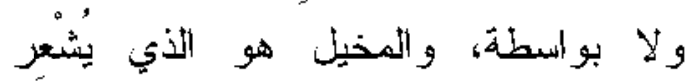


وثانيهما: أن يوجد ذلك في صورتين: وهو

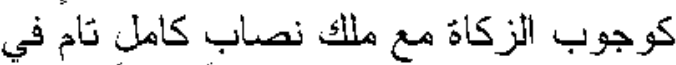

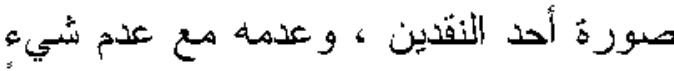

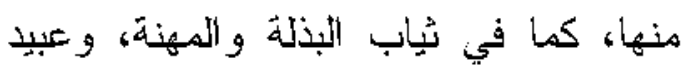

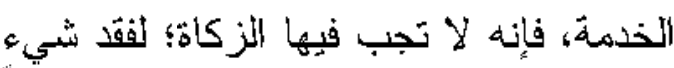

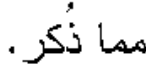

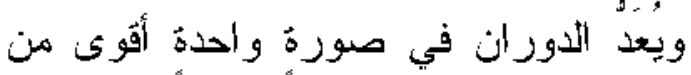
الأوران في صورنين.

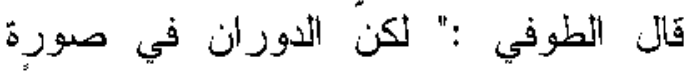

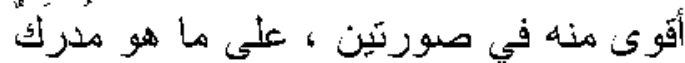

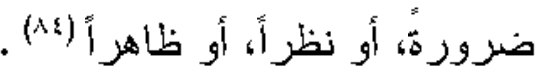

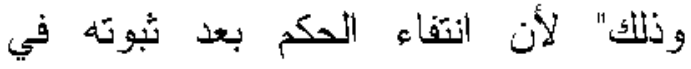

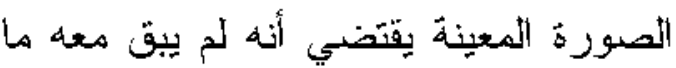

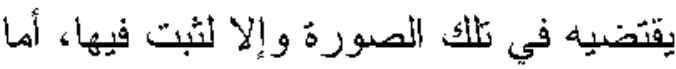
إذا انتفى من صورة أخرث غير صورة

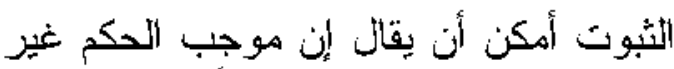

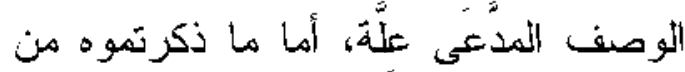
التوصف لو فرض انتفاؤه لنبت الحكم بذلك لكان

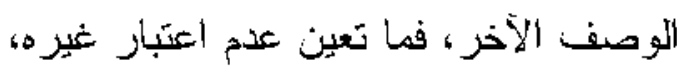

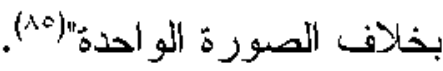
وقد اختلف الأصوليون في إفادة الأدوران اللعلية ، على ثلاثة أقو الن :

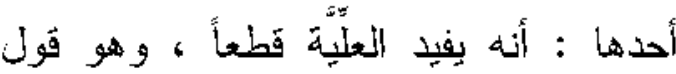

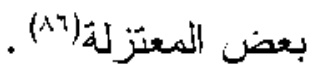

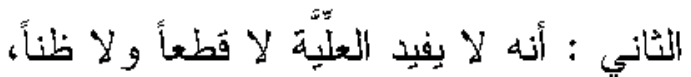

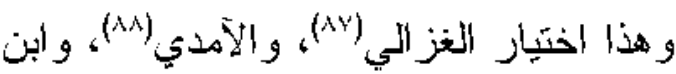
الحاجب(^9).

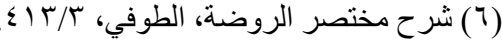

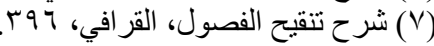

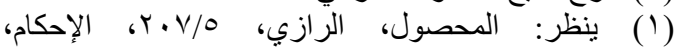

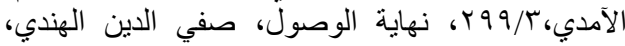

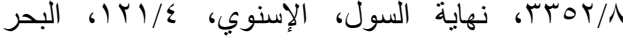

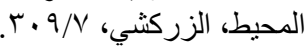

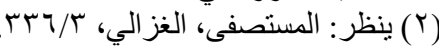

الثوران في اللغة: مصدر دار دوراناً إذا

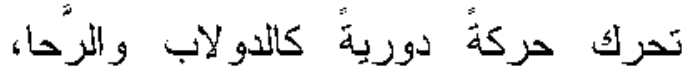

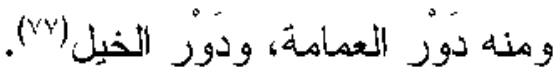
وفي الاصطلاح هو : أن يثبت الحكم بثبوت

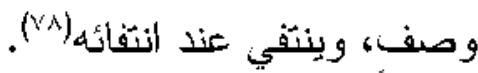

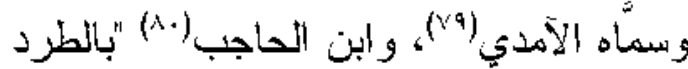
و العكس"؛ لكونه بمعناه، و الطرد في في الأب الاصطلاح : الملازمة في الثلثبوت، والعكس: الملازمة في الانثفاء، ويسمَّى

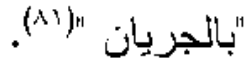
قال الجويني:" ومما ذكره الجدليون ونردد فيه القاضي الطرد و العكس، فذهب كل من

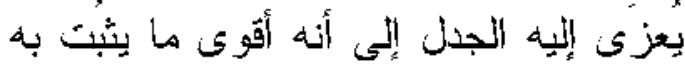

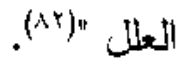

وهو يقع على وجهين (Ar):

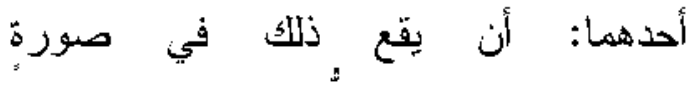
واحدة،كالتحريم مع النُّكر في العصبر ؛ فإنه فئه

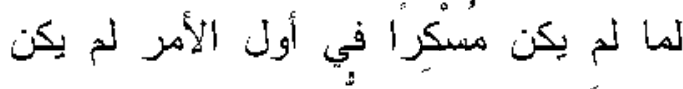

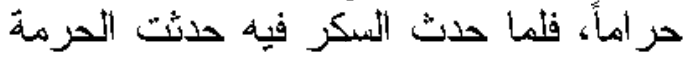

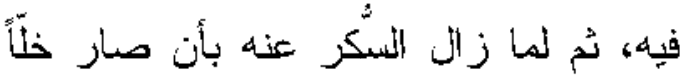
زالت الحرمة عنه.

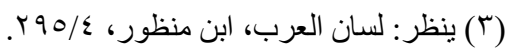

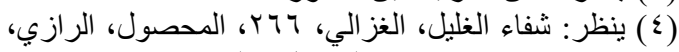


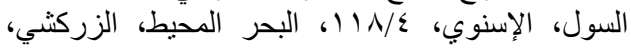

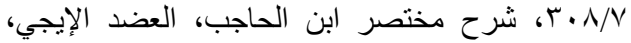
الكوك

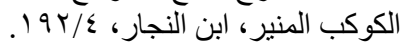

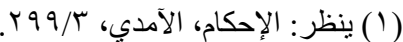

(Y) ينظر: مختصر منتهى الإحك، السول والأمل، ابن الحاجب، $.11 \cdot T / Y$

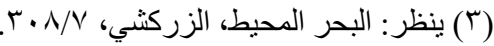

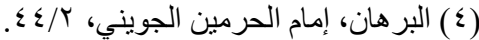

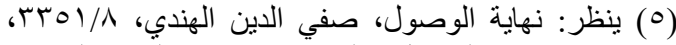

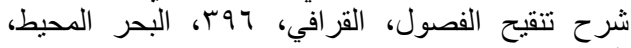

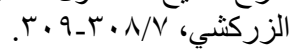


العدم، والدور ان عبارةٌ عن المقارنة وجوداً و عدما" ("9r)

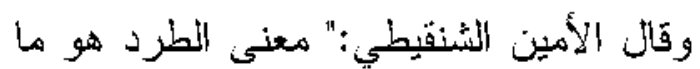

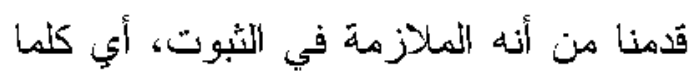

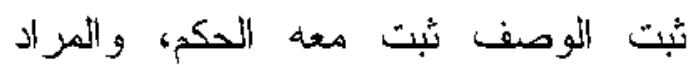

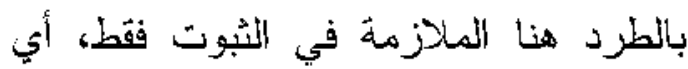
و عدم الملازمة في الانتفاء"(99".

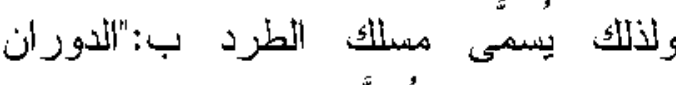

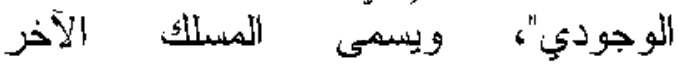

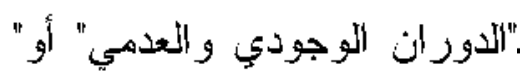

الاوران المطلق" أو" الطرد و العكس "(98). وبعض الحنفية يقصر الدوران على معنى لهن وجود الحكم عند وجود الوصف، الذئي

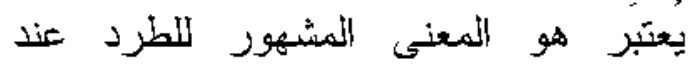

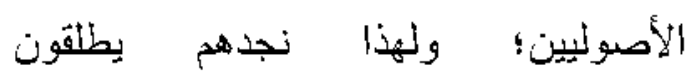

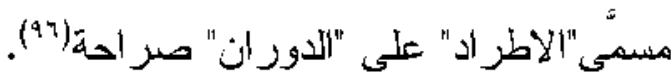
ولتوضيح ذللك نقول (av")

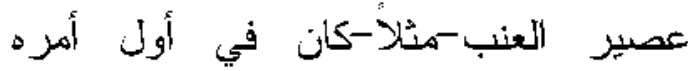

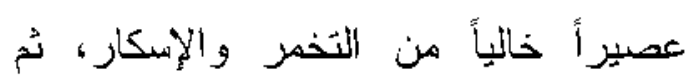

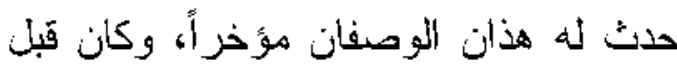

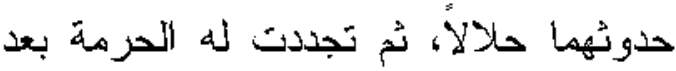

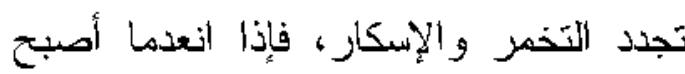

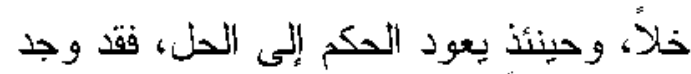

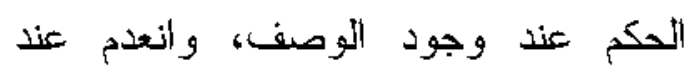
تعده، و هذا هو الدوران.

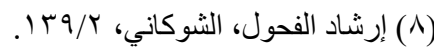

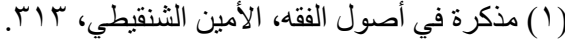

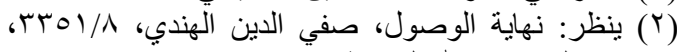

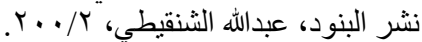

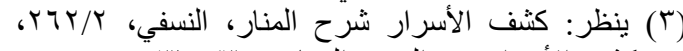

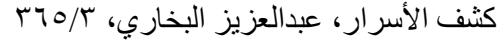

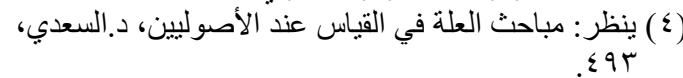

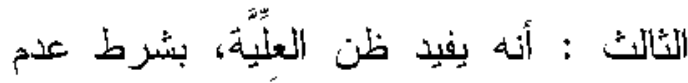

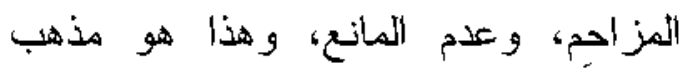

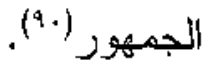
و الفرق بين الطرد و الدوران: أن الاوران

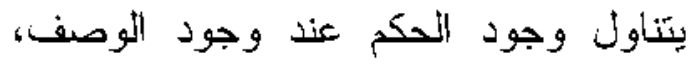
و انتفاء الحكم عند انتفاء الوصف، فيشل علن

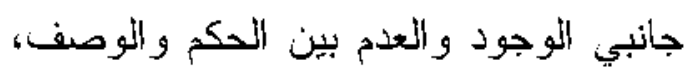
أما الطرد فيخنص بجانب الوجود فئط، فيتناول وجود الحكم عند وجود الوصف

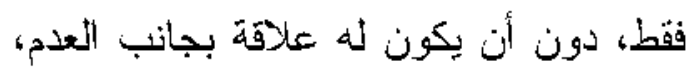
فلا يتناول معناه انتفاء الحكم عند انتفاء الموصف. قال ابن الجوزي:" و لا مشاحة في الأسماء،

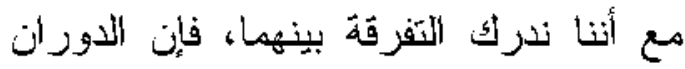

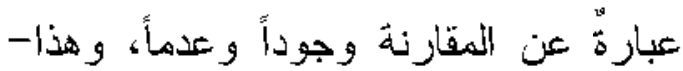

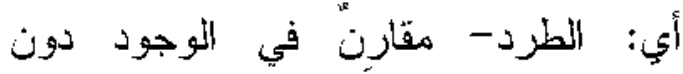

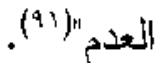
وثال الزركثي:" والفرق بينه وبين الاوران

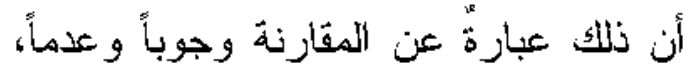

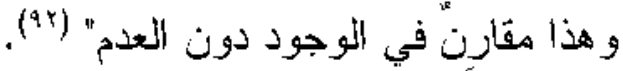
وقال الثوكاني:" وقد جعل بعض لُون أهل الأصول الطرد و الدور ان شيئاً واحداً، ولئس وليس

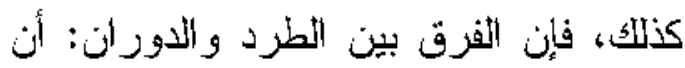

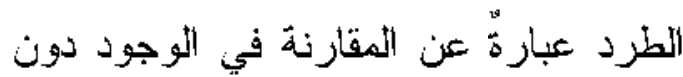

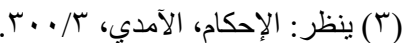

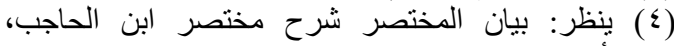

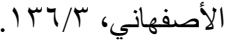

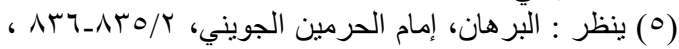

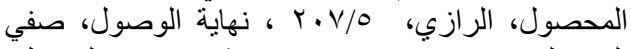

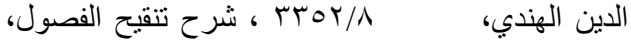

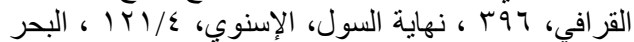

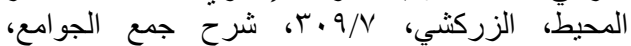

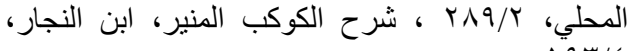


إلتى أن الدوران يُزجّح على الطرد؛ وذلك

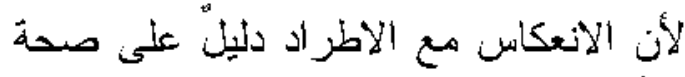

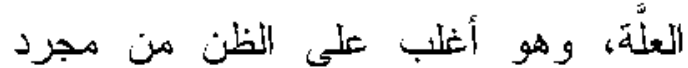

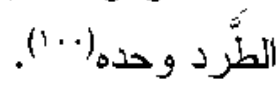

\section{التمبحث الثالث}

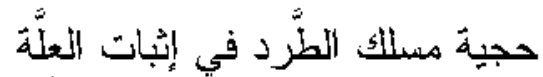
ذهب الأصوليون الذين قالوا: إن مسيلك

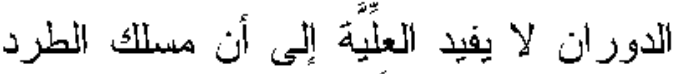

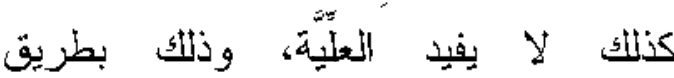
الأولى (1) الأل

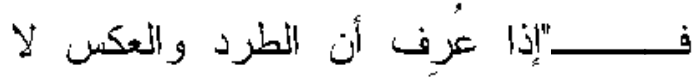

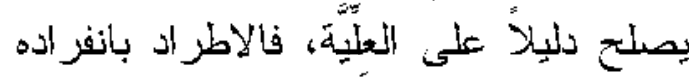

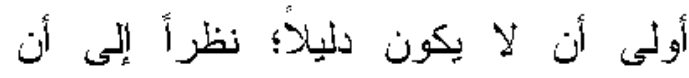

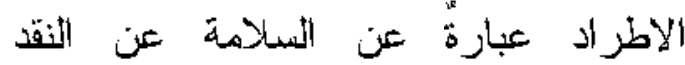

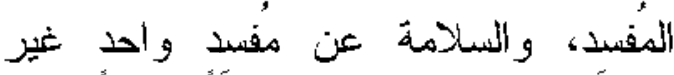
مو جبة للتصحيح" (ب +1). قالل صفي الدين الهندي:" فمن قالم: المُطرّدرد

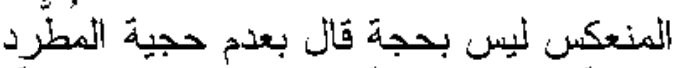

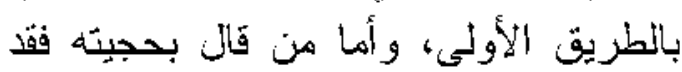

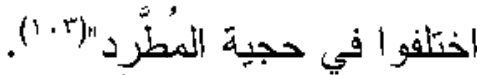

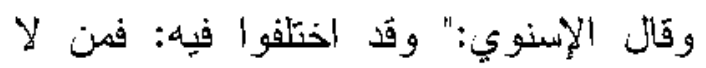

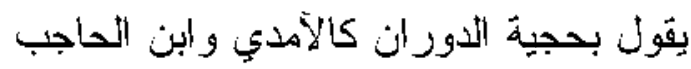

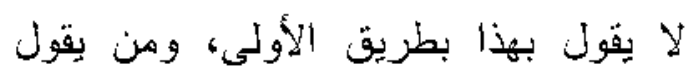

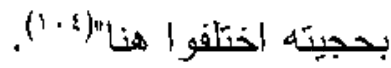

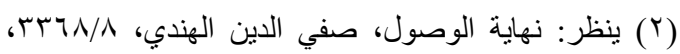

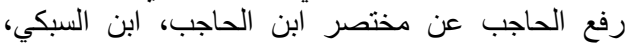

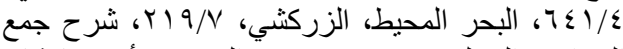

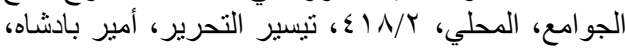

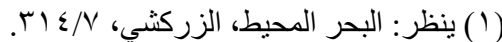

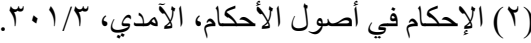

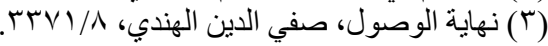

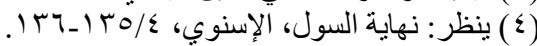

أما الطرد فمثاله: تعليل عدم إزالة النجاسة

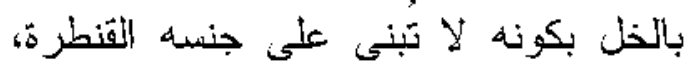

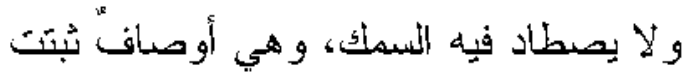

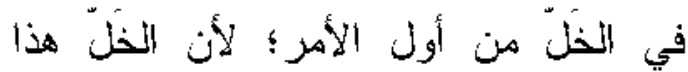
شأنه، فلم نكن الأوصاف حادثةً عليه؛ لأنه

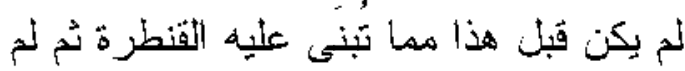
تبن، وبهذا يتبين لنا الطردان، الطرد في لني

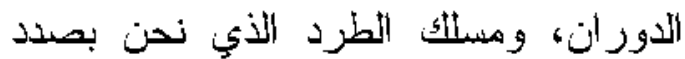
البحث فيه.

ولا يمكن فيه العكس بأن يكون إذا بنيت

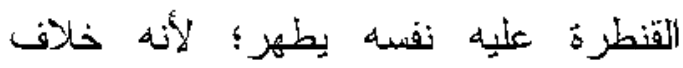

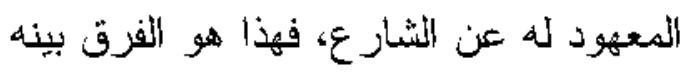
وبين الاوران، فإن الذوران تحقيقه هو أن فئن

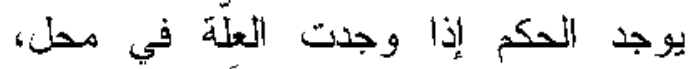
وينتفى بانتفائها في ذلتك ألمحل بعينه، كالحرمة عند الإنكار في الخمر، وعدمها عند عدمه فيه بعينه، وهذا هو المعهود له فئل

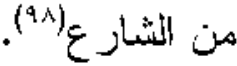
كما أن التوصف في الثوران قدان يناسب الحكم وقد لا يناسبه، أما التوصف في الطرد

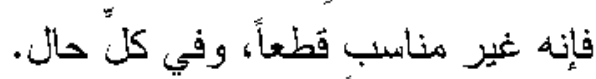

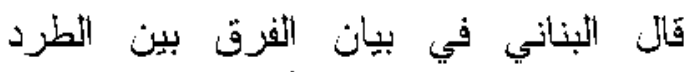
و الاوران:" وأما الطرد فيعتبر فيه المناسبة، فيكون الفرق بين الطرد و الاوران انتفاء المناسبة في الطرد، وصلوح الوصف لها

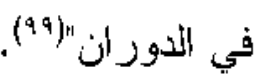
وبناء على ما تقدم ذكره من بيان الفرق بين الطرد و الدوران فقد ذهب عامة الأصوليين

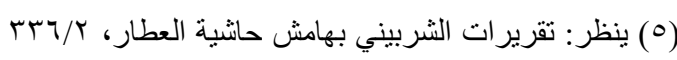
酒 (1) حاثنية على شرح المحلي على جمع الجوامع، البناني،
} 
وقال ابن السمعاني: "قياس المعنى: تحقيق،

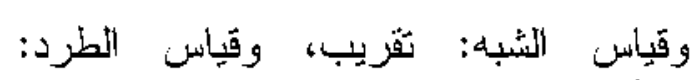

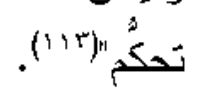

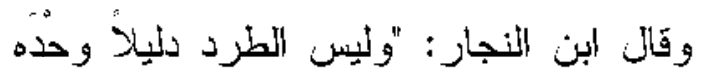

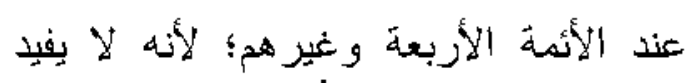

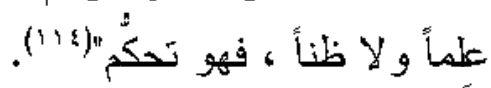

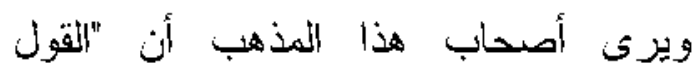

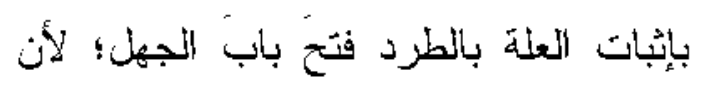

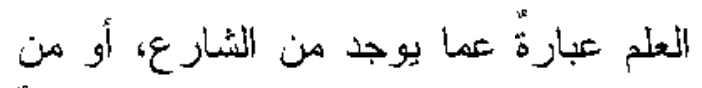

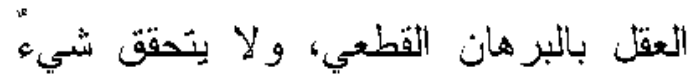

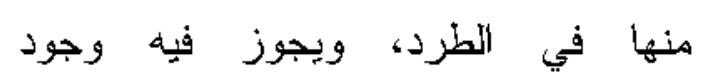

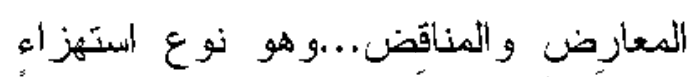

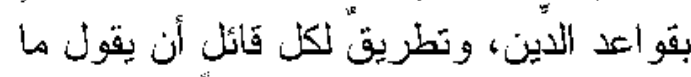

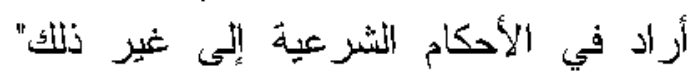

وقد أسنتل أصحاب هذا القول بما بأثي:

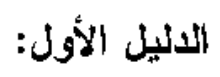

أن أقيسة المعاني لم ثقتض الأحكام لأنفسها،

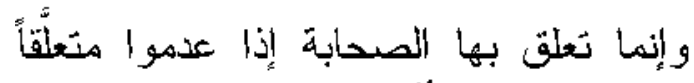

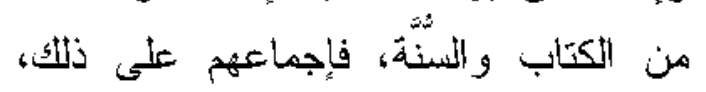

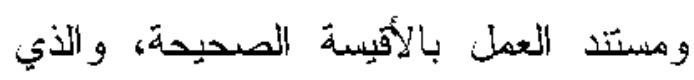

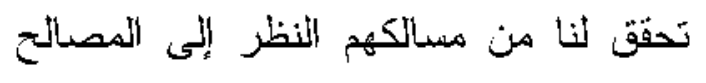

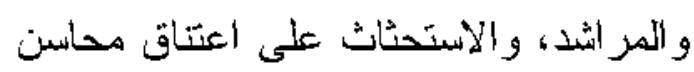

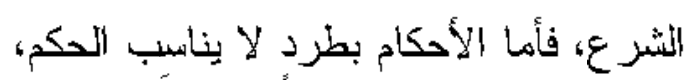

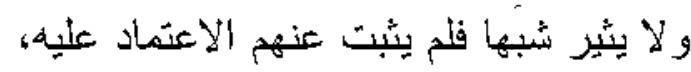

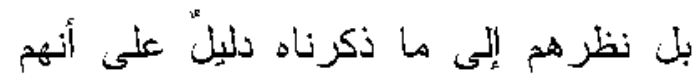

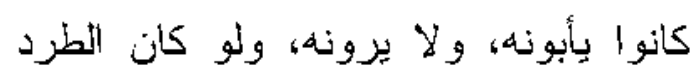

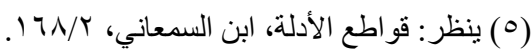

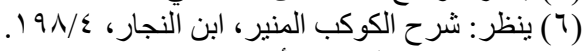

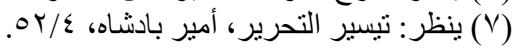

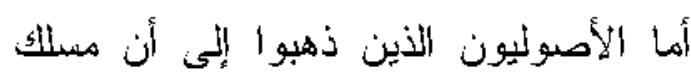

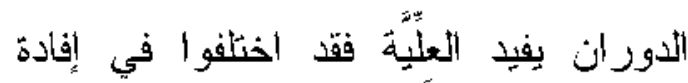

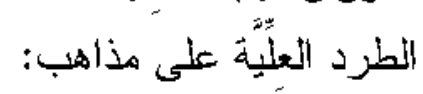

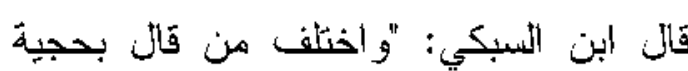

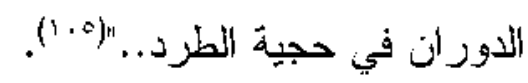
المذهب الأول: أن مسلك الطرد ليس بحجة الطرد مطلقاً.

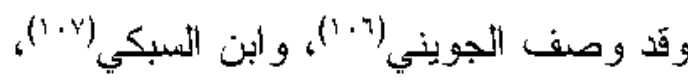

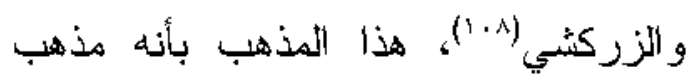
المعتبرين من النظًّر .

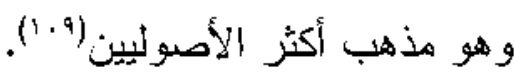
وبه يقول جمهور الفقهاء و المنكلمين ('1"). وقال إمام الحرمين: "ونتاهى القاضي -أئي:

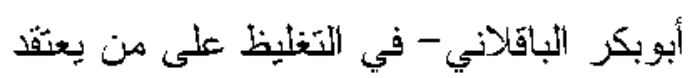

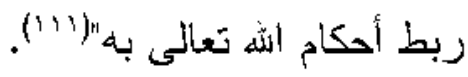
وقال:" لو كان التمسك بالطرد سائغاً لما

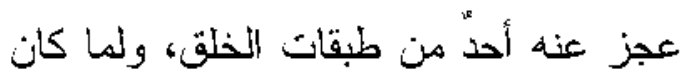

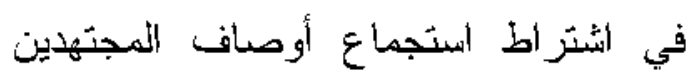

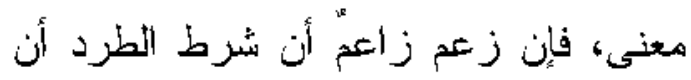

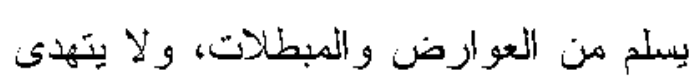

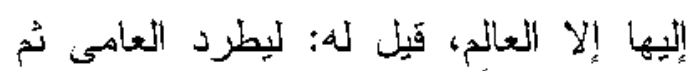

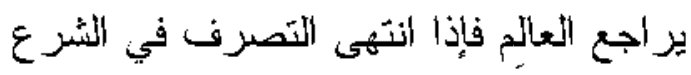

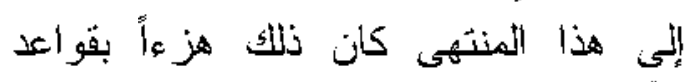
النّيّن "(i) (1)

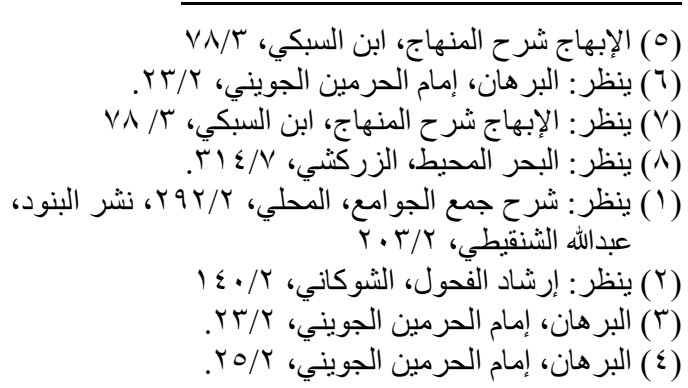


قالل ابن السبكي عقب إيراده هذا الدليل:" ولسنا نطيل بالرد على التقائل بالطرد ففي

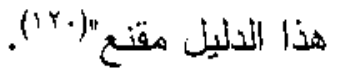
وقال عيسى منون: "وخلاصتَه أن أهم مستند للعمل بالقياس إنما هو عل الصحابة به، وعملهم كان قاصرأ على قياس العلة، و الثبَه، دون قياس الطرد، ثم إنه إذا بطل

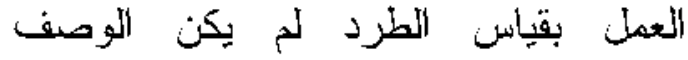

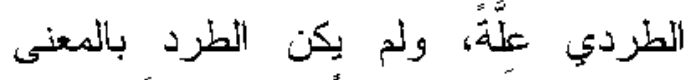

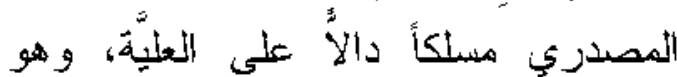

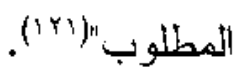

\section{الأليل الثاني:}

أن الاطر اد عبارةٌ عن كون الوصف بحيث لا يوجد إلا ويوجد معه الحكم، وهذا لا لا

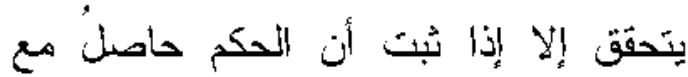
التوصف في صورة النزاع، فإذن ثبوت الاطر اد يثوقف على ثبوت الحكم في صورة النزاع، فلو أثثب الحكم في صورة النزاع

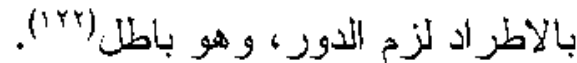

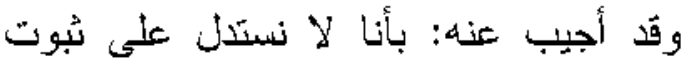

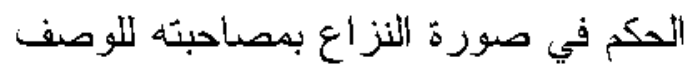

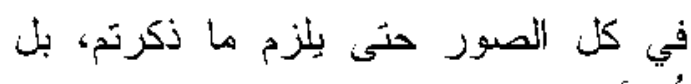

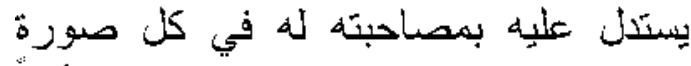

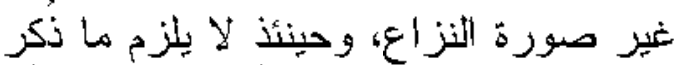

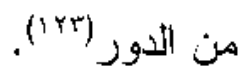

وقال عيسى منون: "و هذا الأليل ضعيف؛ لونئ لأن الطرد مقارنة التوصف للحكم فيما عدا

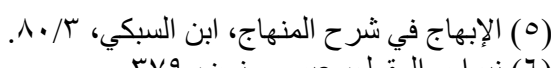

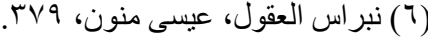

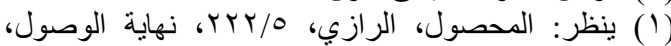

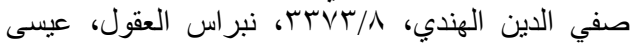

مناطاً لأحكام الهل تعالىى لما أهملوه ولا عطلوه (117) وقد أستمرت الطريقة دالةٌّ على ذلك من وجهين: أحذهما: أنه ليس للظرد مستنّ" معلومّ" ولا مظنون، وليس هو في نفسه مقتضياً حكماً

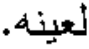
والآخر: أنا نعلم إضراب الصحابة رضي الله عنه عن مثله في النظر في أحكام

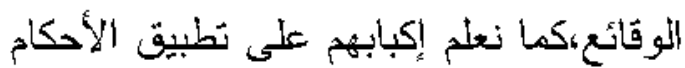
على المصالح الثرعية، وهذه طريقة

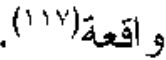

إذ المنقول عنهم العمل بالمناسب دون غيره| (1) (1) قال ابن السمعاني:" إجماع الصحابة هو

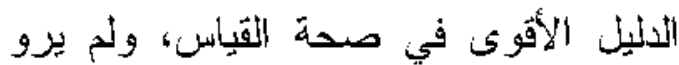
عن احد منهم أنه نتلق بطرد لا يناسب

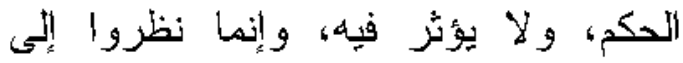
الأقيسة من حيث المعانى، وسيلكوا طريق وإنى المرائد والمصالح التي تشير إلى محاسن

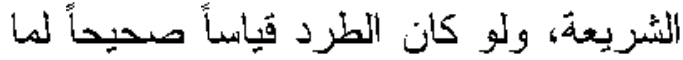
عطلوه، ولما أهملوه، ولما تركوا الاعتلانل

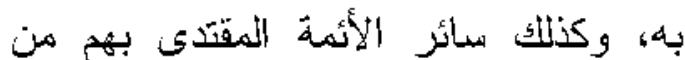

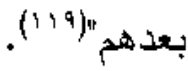

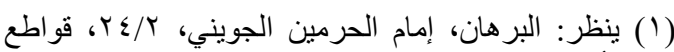

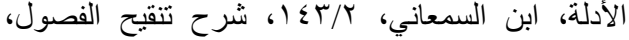

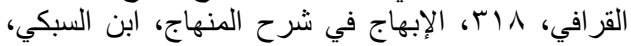

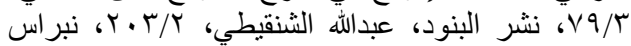

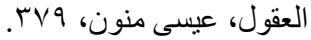

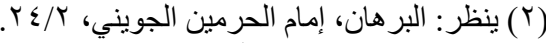

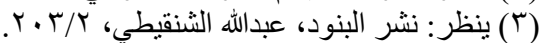

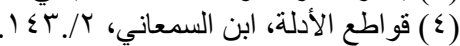


دليل وجود المطر، وإن تخلّف عنه في بعض الصور لا يقدح في كونه دليلا، وأيضاً المناسبة والثدوران والتَأثير و الإِيماء

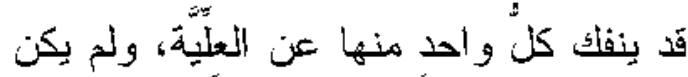

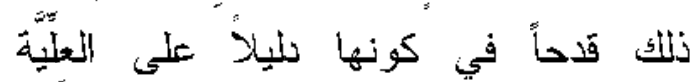

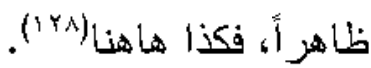

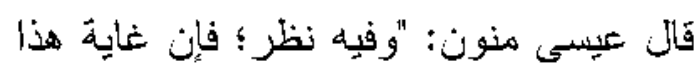

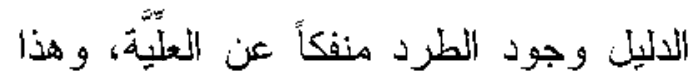
لا يقدح في دلالته على العلية ظاهر أ، فإن معظم الممسالكاك كالمنانبب و الإِيماء و الدوران

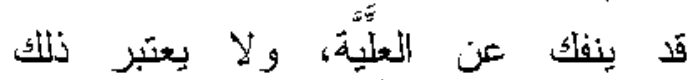

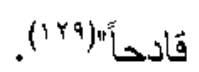

\section{الالديل الثرابع:}

أن الطرد فعل الطارد(القائن)، و لا شيء من العلل الثشرعية يثبت بفعل الإنسيان، فلا شيء من الطرد بعلَّة (1r).

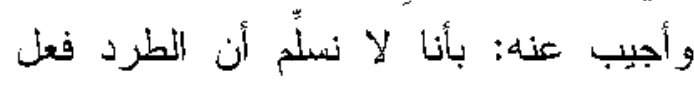

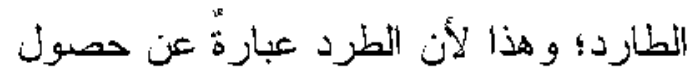
الحكم في جميع محال الوصف غير صورة النزاع، وذلالك ليس بفعل الإنسان، بلن بفعل الثارع. نعم حصول الحكم في محل الاجتهاد بتعلق بفعله؛ حيث إنه عدئ الحكم من الأصل إلّيه

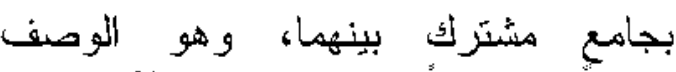

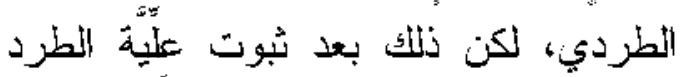

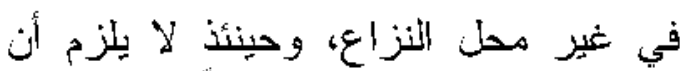

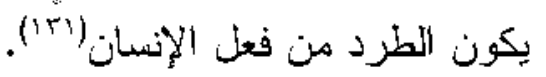
الاليل الخامس:

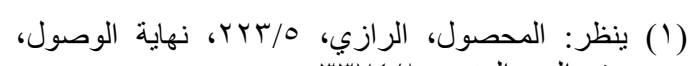

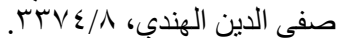

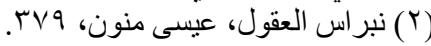

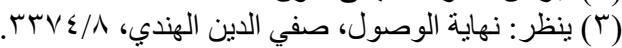

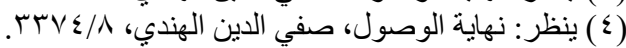

الفرع كما سبق، فالاستذلال بمصاحبة الوصف للحكم في جميع الصمور ماعدا

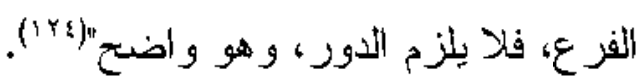

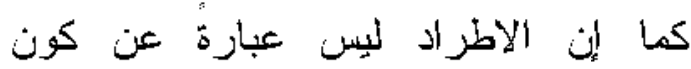

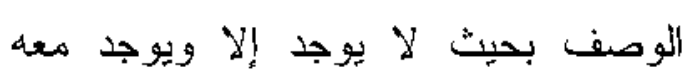
الحكم كما ذكرثم حتى يقال أن ذلك ليس

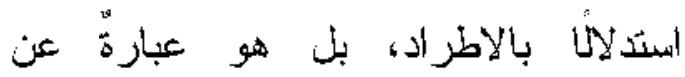
التوصف الذي لا يكون مناسباً، و لا مستلزماً

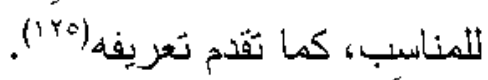
|الأيل الثالث:

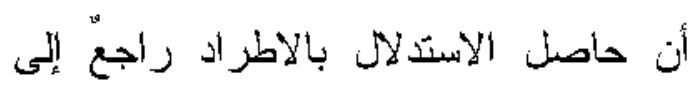

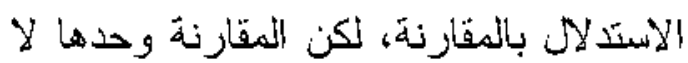

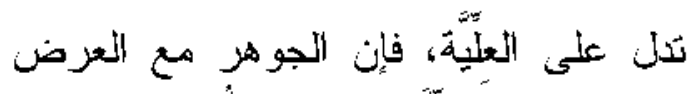

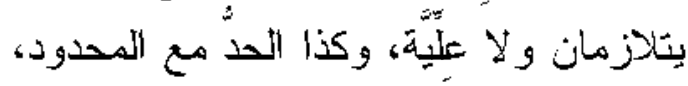

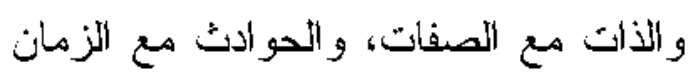

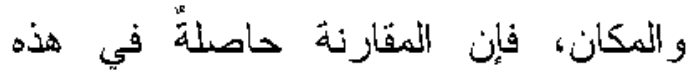

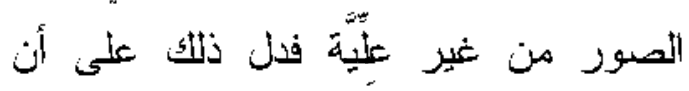

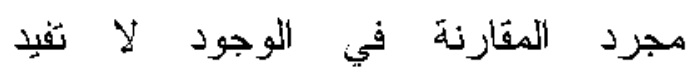

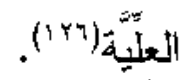
وقد أجبب عنه من وجهين: الأول: أن كلامنا في المقارِن الأبي لُ يدل

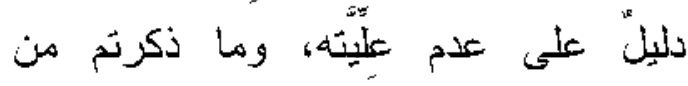

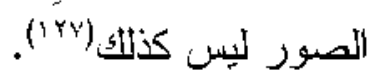

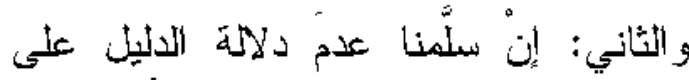

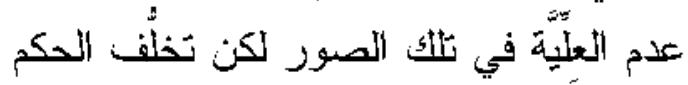

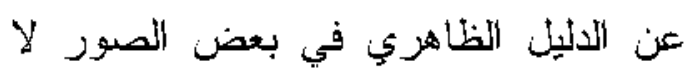
يقدح في دلالته، كما في الغيم الرطب، فإنه

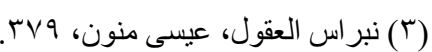

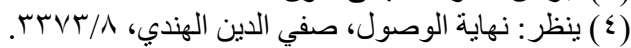

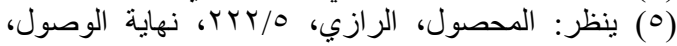

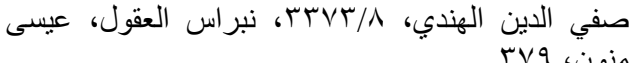
(ך) ينظر : نهاية الوصول، صفي الدين الهندي، 
مسألة مس" "الذكر : طويل" مثنقوق" فلا تنتقض الطهارة بلمسه كالبوق، إلى غير ذلتك من

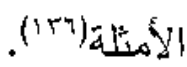

وقد أجيب عذه بأن: ذلك الكلام بدل على لإلى

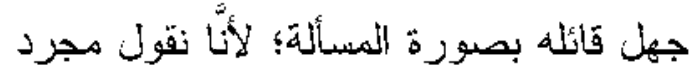

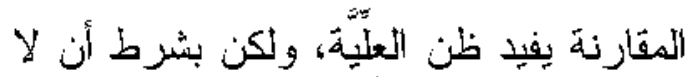

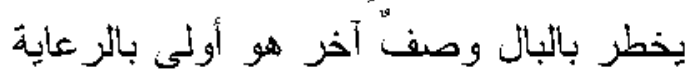
مذه، ولكن هذا الشرط ساقطٌ عن المعلِّّ،

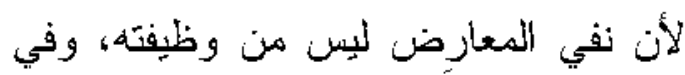
هذين المثالين إنما يبطل ذلتك؛ لأن العلى

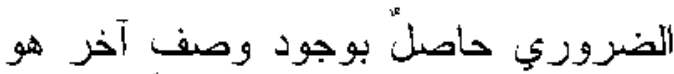

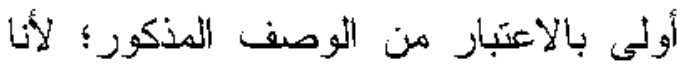

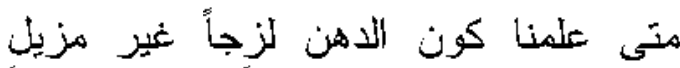

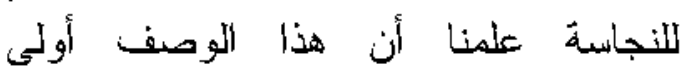
بالاعنَّار من كونه بحيث لا تُبنَى القنطرة

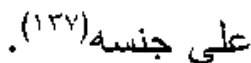

فإن قَيل: هل يكفى في القدح في مثل هذا التُعليل خطور وصف آخر بالبال؟ فالجواب: لا؛ لأن ذلأك التوصف الآخر إما

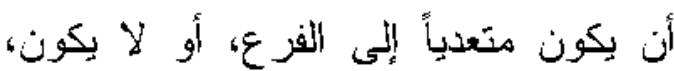

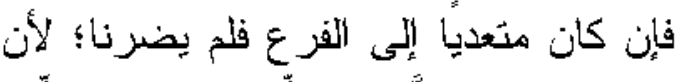

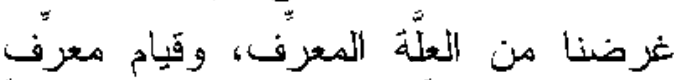

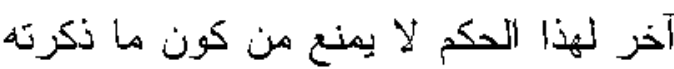

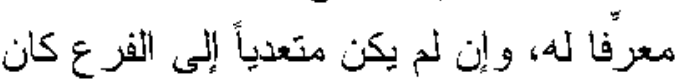
التعليليل بالوصف الأي ذكرئه أولى؛ لأنا

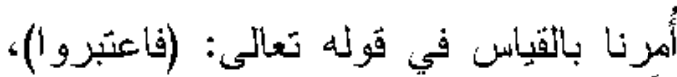
والأمر بالقياس أمز" بما هو من ضروراته،

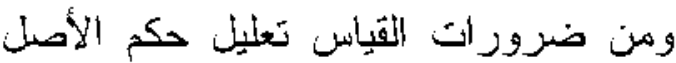

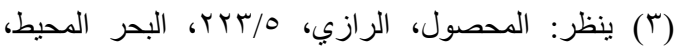

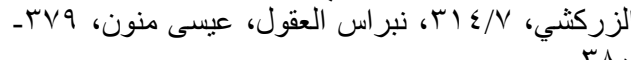

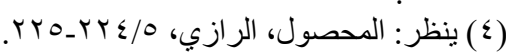

أن الؤفف الطردي ليس فيه إلا سلامتَه

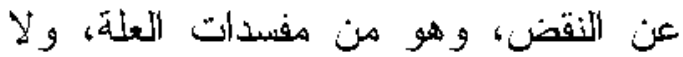
يلزم من سلامة الثشيء عن مفسدات العلة أن يكون عنَّة (1+1).

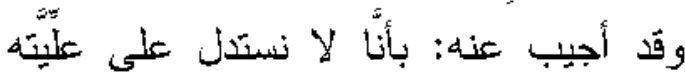

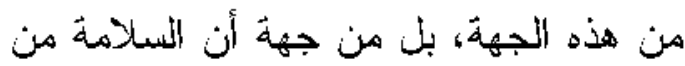

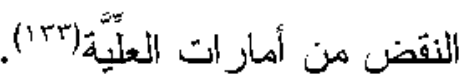

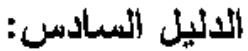

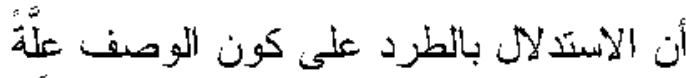
تصحيح" للاعوى بالدعوى؛ فإن كون ذلك الك

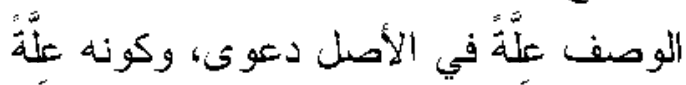
في غيره دعوث أخرث، فنسحيح الأولى فئل

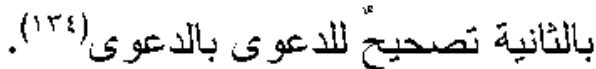
وقل أجيب عنه: بأن الدليل على كون

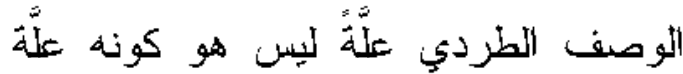

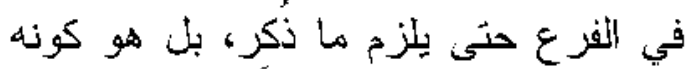

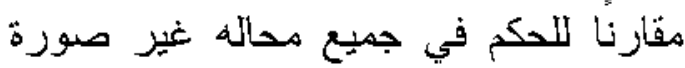
النزاع، وذلك ليس دعوى تحتاج إلى الدليل،

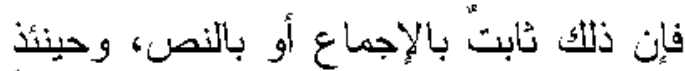

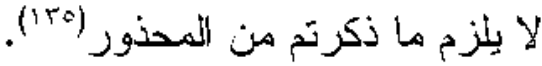

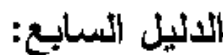

أن تجويز العمل بالطرد خصوصاً على

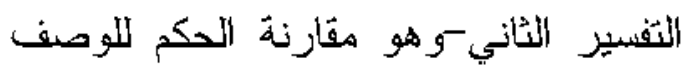
ولو في صورة واحدة- يفتح باب الهذيان،

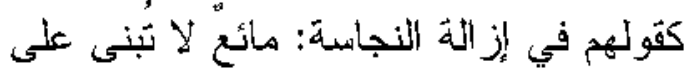

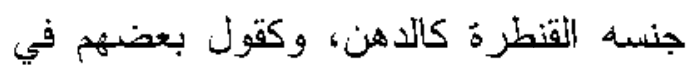

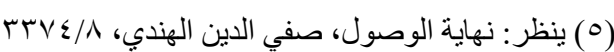

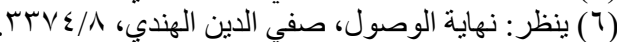

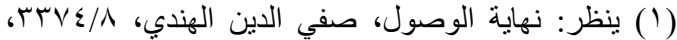

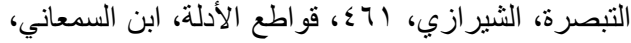

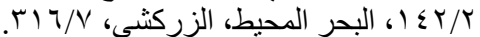

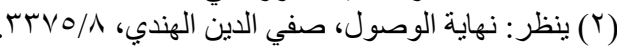




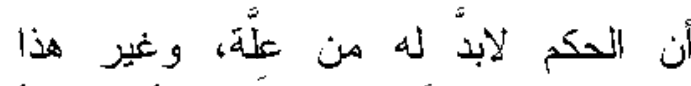

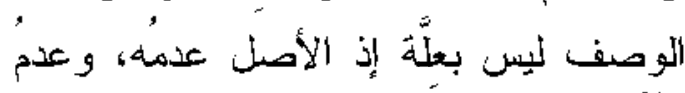

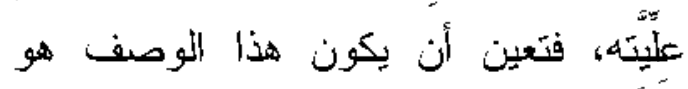
التعلَّة (1)

وقد أجيب عنه: بأن ظن انتفاء الغير إنما

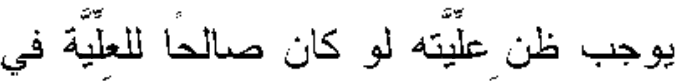

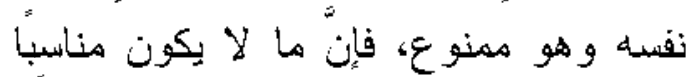

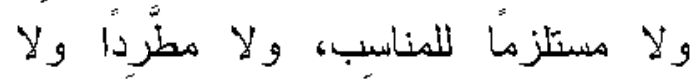

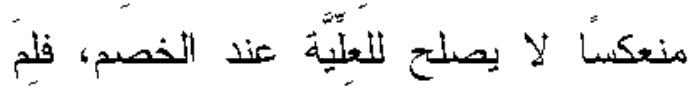

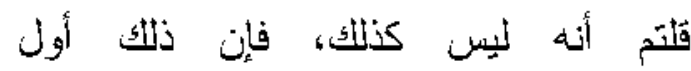

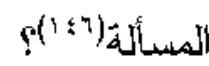

كما أجيب عنه بأن: القائل بالطرد يبيتند إلى لي

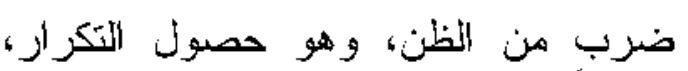
والصورة الوالحدة لا نكرار فيها، فمن أين ونئ الظن

\section{الأليل الثاني:}

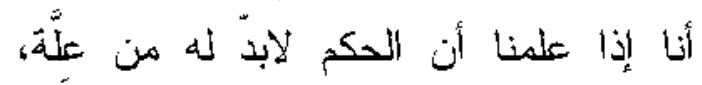

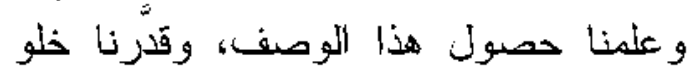
ذهننا عن سائز الأوصاف، فإن علمنا بأنه

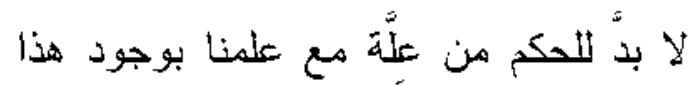
الوصف بقتضبيان أعثاد كون هذا الحكم معلَّل بذلك التوصف؛ إذ لو لم يقتض ذلتك

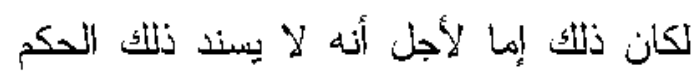
إلى شيء، أو لأجل أنه بِينده إلى شئ

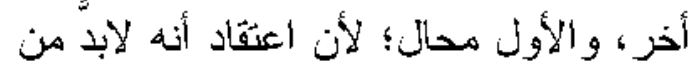

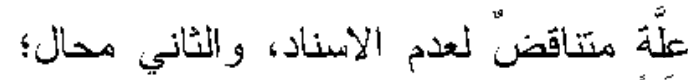

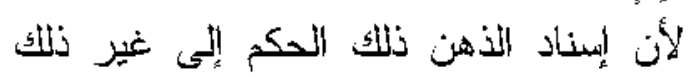

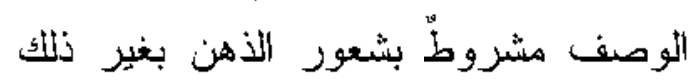

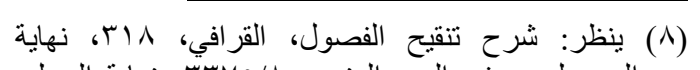

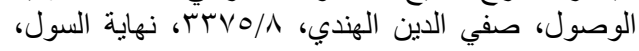

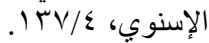

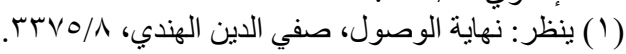

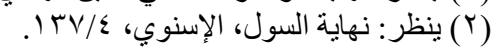

بعلَّة متعديةٍ، فكان التُعليلِ بما ذكرناه أولى

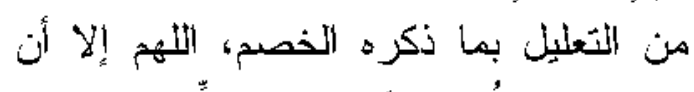

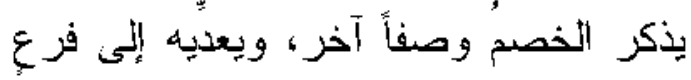

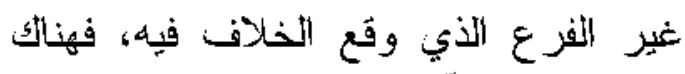

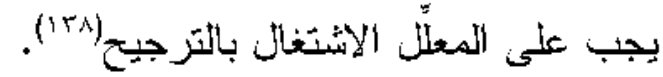
الاليل الثئه:

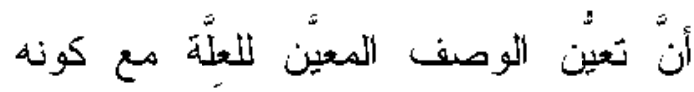

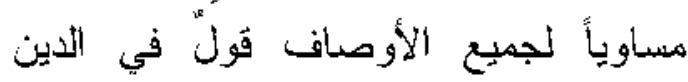

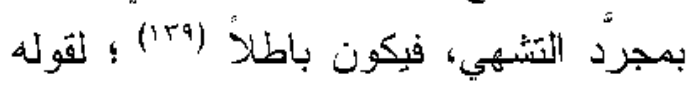

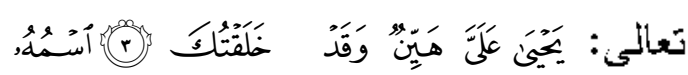
[مريم:409] وقد أجيب عن ذلأك بأنّا: بينًا أن مجرةّ

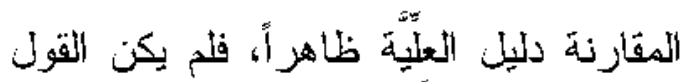

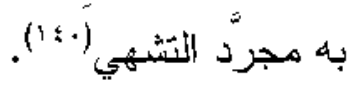

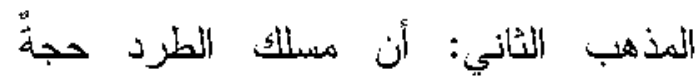
مطلقاً.

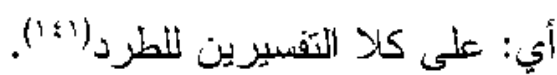
فهو حجةٌ مطلقاً، وتكفي المقارنة ولو في

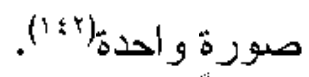

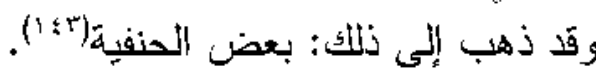

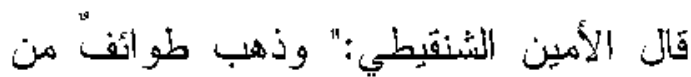

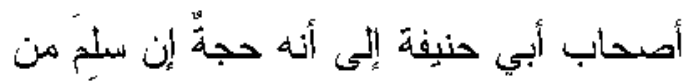
الانتقاض وجرى على الإطر اد" (؛؛ ؛ 1).

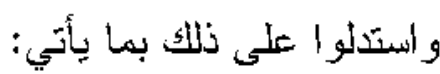
الأليل الأول:

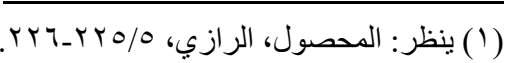

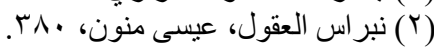

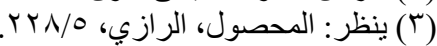

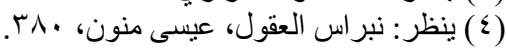

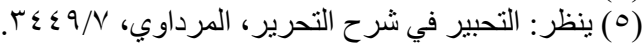

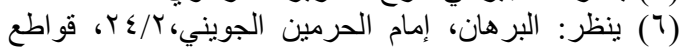

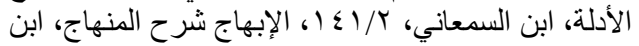

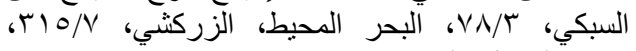

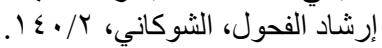

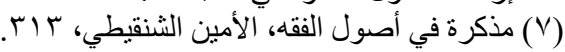




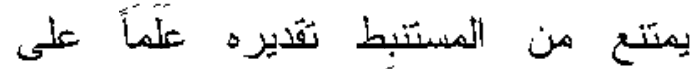

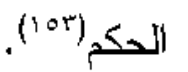

وقد أجيب عذه: بأن هذا القول لا حاصل له،

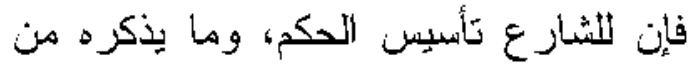

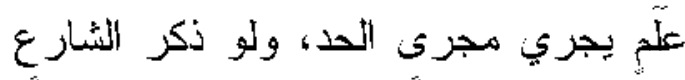

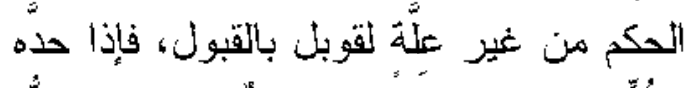

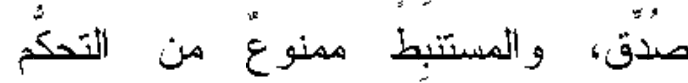

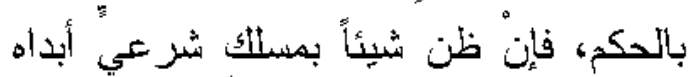

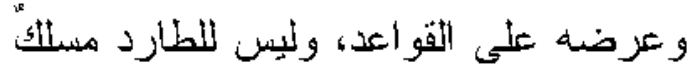

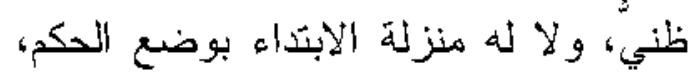

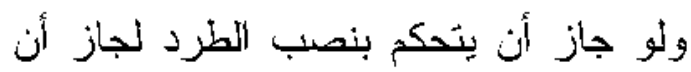

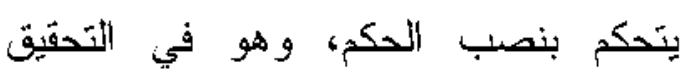
كذلاك، فإن الطارد بِتحكم بالحكم في صورة

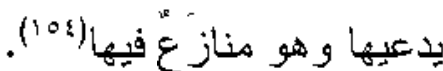
الأليل الثر ابع:

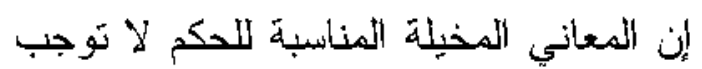

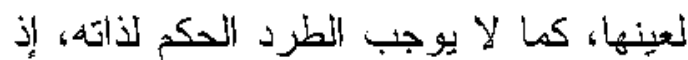
الثدة التي اعتقلت مخيلة في إنارة التحريم كانت ثابتَّة والخمر حلال، فإذن العلل كلها

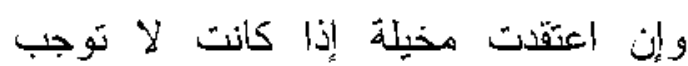
الأحكام لأعيانها فهي كالطرد (100).

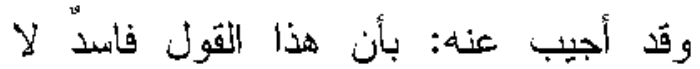
حاصل له، فإنا لا نرتضى المخيل من جهة الإخالة، ولكن إذا صادفناه وظنناه مو افقاً لعلل الصحابة ومسالكهم رضي الله عنهم في النظر فهو الاليل على وجوب العمل لا لاليال نفس الإخالة، ولم يثبت تصسك الصحابة بالطرد، فلا يبقى للمستنبط وجهّ يبني عليه

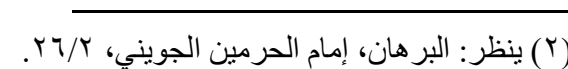

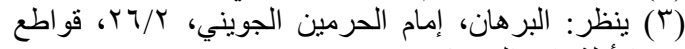

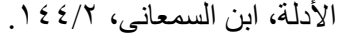

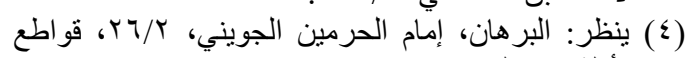

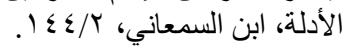

التوصف، وتحقق ذلك حال خلو الذٔهن من الشعور بغير ذلك الوصف محال، فثبت بهذا

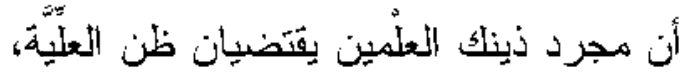
بل عند الثشعور بوصف آخر يزول ذلتك

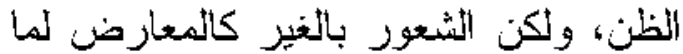
يقتضى ذلتك الظن، ونفي المعارِض ليس على المستخل (1) (1). وقد أجيب عن ذلتك: بأنه لا منافاة بين عدم الثشعور بالغير على سبيل التفصيل وبين الثشعور به بلى سبيل الإجمال، واللازم إنما هو الثشعور بالغير على سبيل الإجمال،

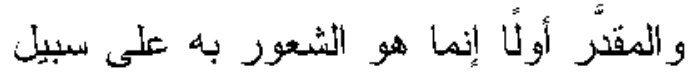

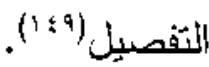

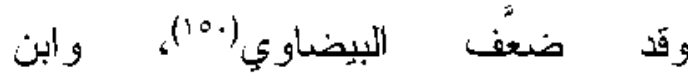
السبكي(101) هذا القول؛ وذلك لأن الثبائل بالطرد بِيتند إلىى ضرب من الظن، وهو

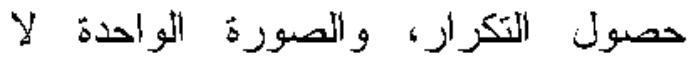
تكرار فيها، فمن أين الظن؟ قال عيسى منون: "وفيه نظر فإن خلو الذهن

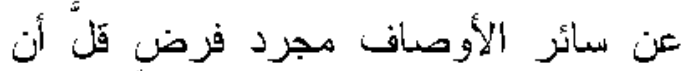
يقع من مجتهد يسعى للوصول إلىى ما يشير الظن "(10) (1).

\section{ألانيل الثالث:}

يجوز للثار ع أن ينصب الطرد سلمًَاً وإن لم يكن مناسبا للحكم، وإذا لم يمتتع ذلك لم لم

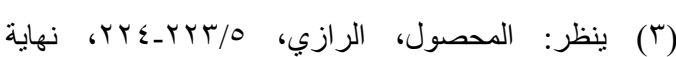

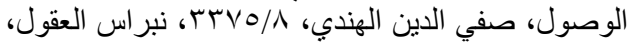

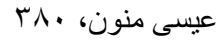

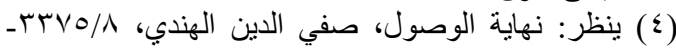
(2) (0) ينظر: منهاج الوصول مع شرحه الإبهاج لابن السبكي،

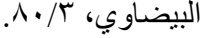

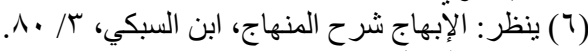

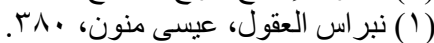


قال الأمين الثشنقيطي: "وذهب كثير" من

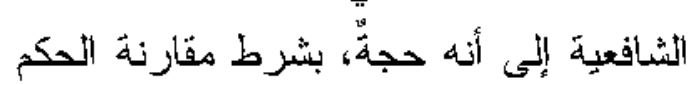

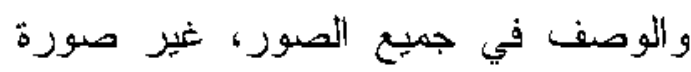

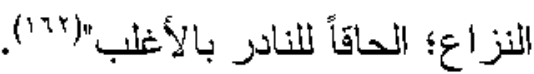

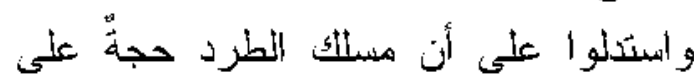

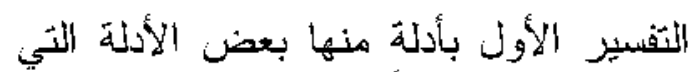

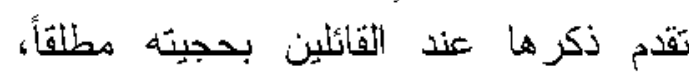
وهي على النحو الآتي:

\section{الدليل الأول:}

أن الستقزاء الثرع عيلن على أن النادر في

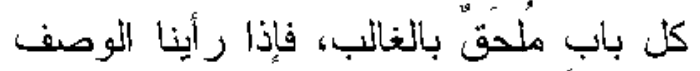

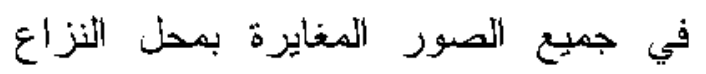
مقارناً للحكم، ثم رأينا الوصف حاصدلاً في

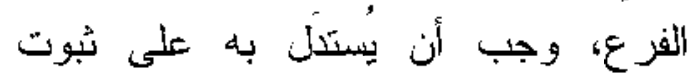
الحكم؛ إلحاقا لتلك الصورة التو الحدث بسائر الصسور (17r)

وتقزيزه على القانون المنطقي أن تثول: كلما ثبت الحكم هـع التوصف في جميع

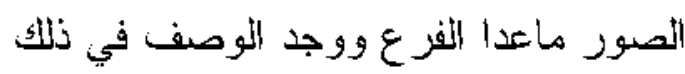

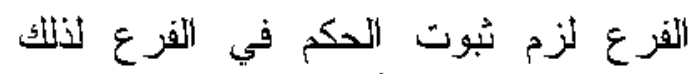

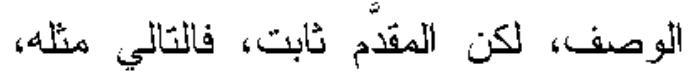

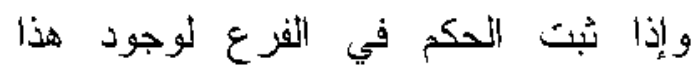
الوصف الطردي كان هذا الؤوصف علَّةً وكان الطرد بالمعنى المصدري مسيلكاً

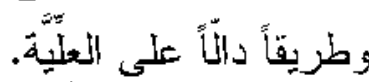
أما كبرى الالنيل فوجه اللزوم فيها: أنه لو لـ لم

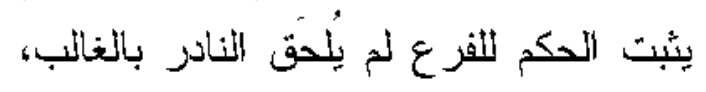

(T) مذكرة في أصول الفقه، الأمين الثنقيطي، با بآ.

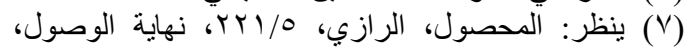

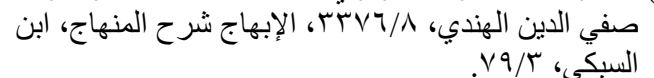

الظن بأن ما طرده منصوب الشارع، فألّ

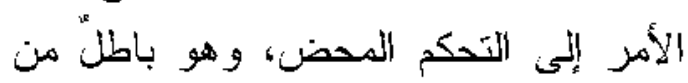
دين الأمة (107).

\section{ألدليز الخامس:}

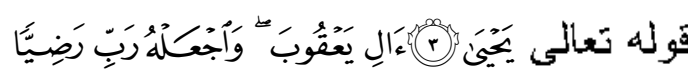

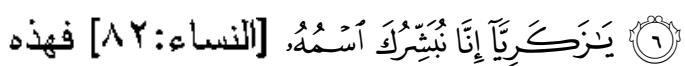

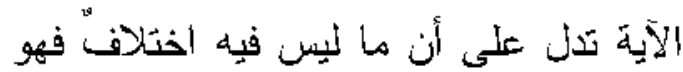

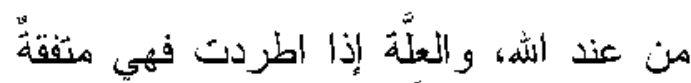
لا اختلاف فيها، فوجب أن تكون من عند (10Y) اله

وقد أجبِ عنه: بأن الآية تذل على أن ما فيه اختلاف فلفيس من عند الله، ونحن نقول به، فإن الاختخلف في العلل هو الإقضن، وذلأك يدلن على أنه ليس من عند الهه، وليسل

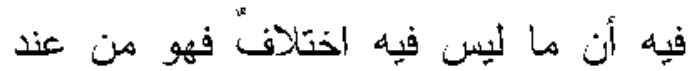

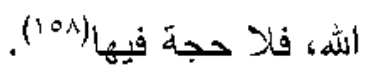

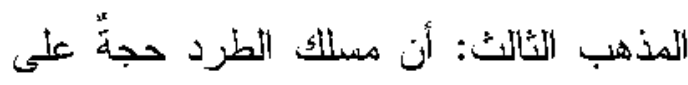
النقسير الأول، وهو أن يكون الحكم حاصدان مع الوصف في جميع الصور المغايرة لصورة النزاع، وليس بحجة على الثفسير الثاني، و هو أن يكون الوصف مقارناً للحكم ولو في صورة و أحدة. أي: إن قارن الحكم الوصف ولو في صورة واحدة غيز صورة النزاع ألحاقا للفرد بالأعم الأغلب (109).

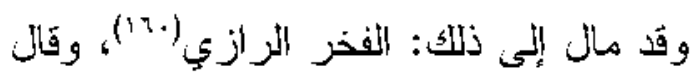
به البيضاوي (17)

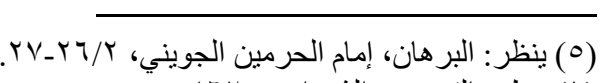

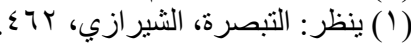

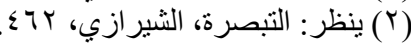

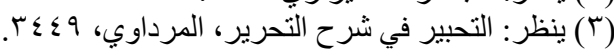

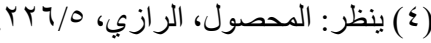
(0) ينظر: منهاج الوصول مئول الرئ شرحه الإبهاج لابن السبكي، 
وإن أر اد أن الثارع ألحق النادر بالغالب في

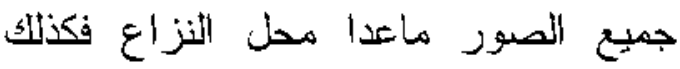

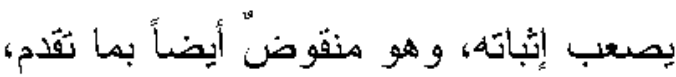

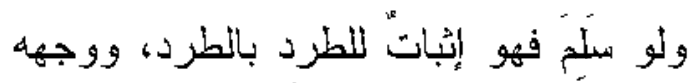

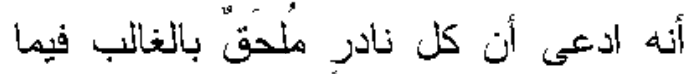

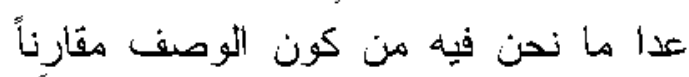

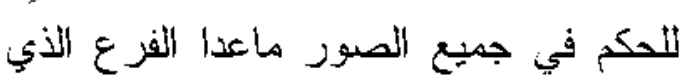
تحقق فيه ذللك الوصف، فيجب أن يثبت له له

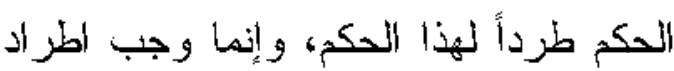
هذا الحكم لأجل اطراد قاعدة الحاق الثنادر بالغالب، فلا تكون القاعدة مطردة، فلاطر ادها يجب اطرز اد هذا الحكم، فقد أنثبتنا

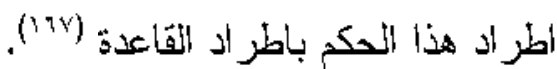

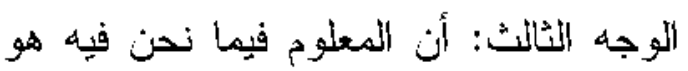

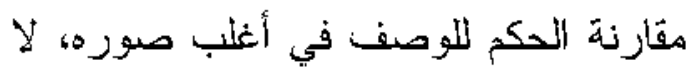

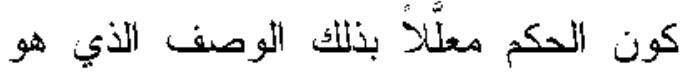

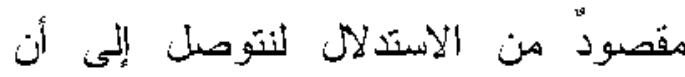

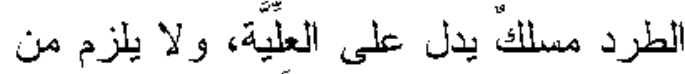

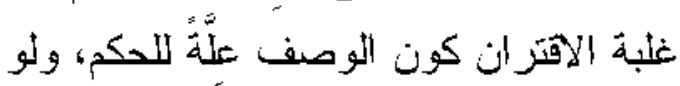

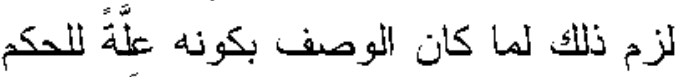

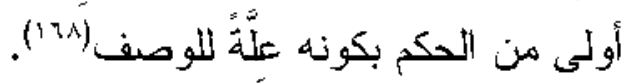

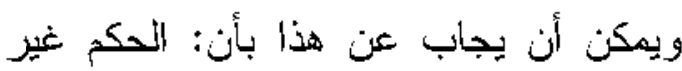

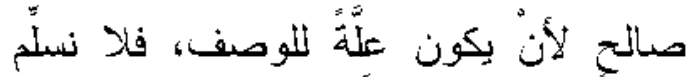

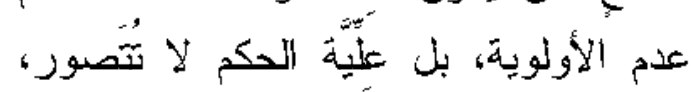

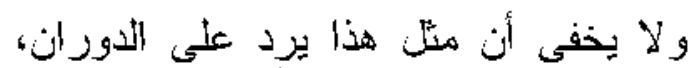
و الجو اب هو الجواب(1799).

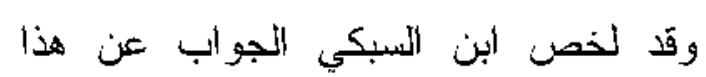
الاستيلال: بأنه إن أريد بالاستقراء إلحاق
لكن التالي باطل؛ لأن الاستقز اء دل على أن

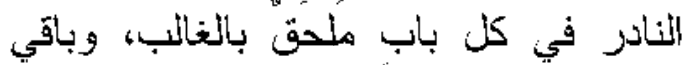

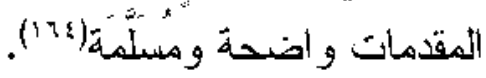

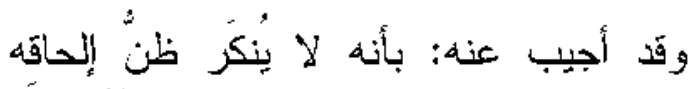

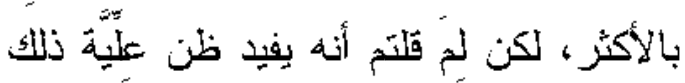

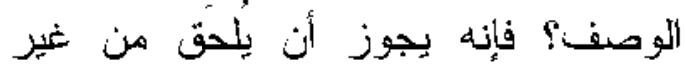

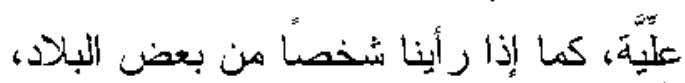

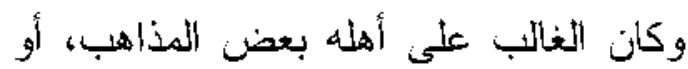

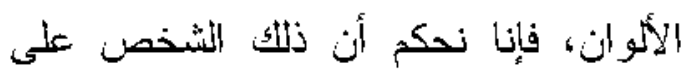

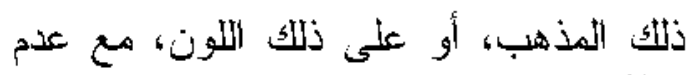

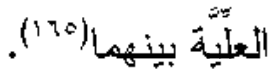
وهذا الدليل مشكلّ من وجوه، منها:

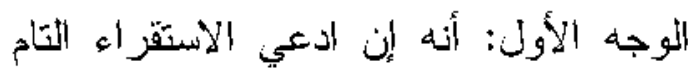

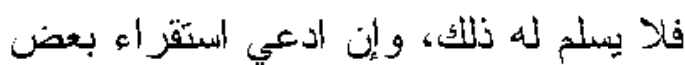
الأحكام فلا يجديه نفعاً (137)

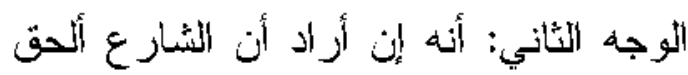
النادر بالغالب فلا يفيد شيئا، و إن أر إد أنه أنه

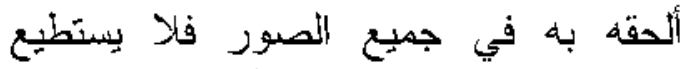

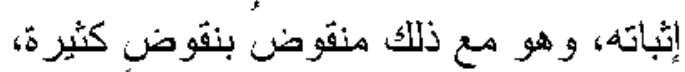

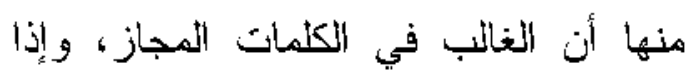

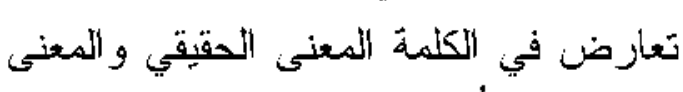
المجازي حملت على الحقيقة، ومثلها.

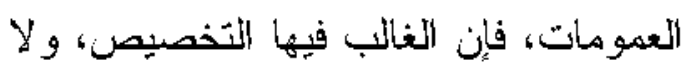

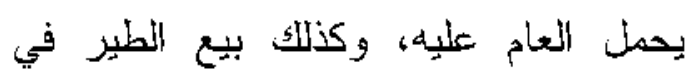
الهواء، و المسك في الماء، وسرقة حبة من

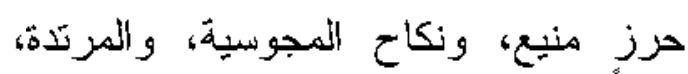

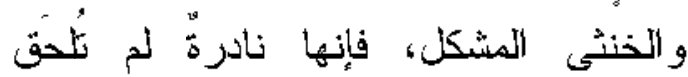

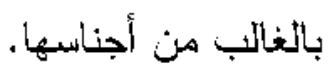

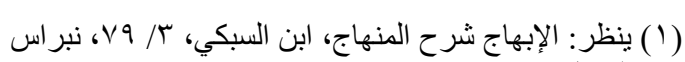

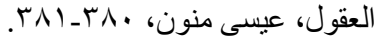

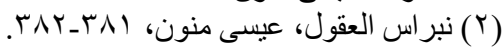

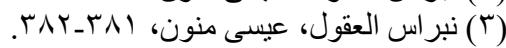


أن الحكم بكون ذلتك الوصف علِّةُ مع أنه

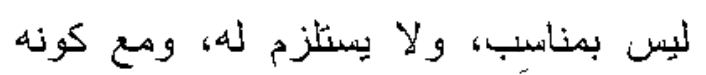

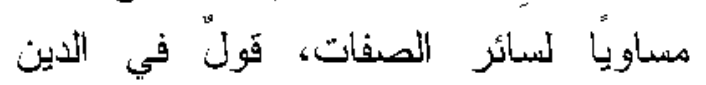
بمجردّ التشتهي، فيكون باطنًا.

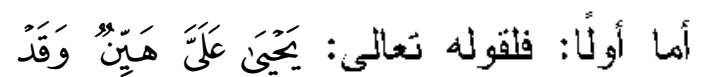

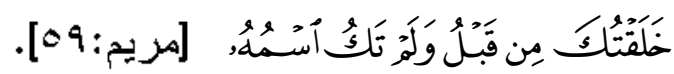

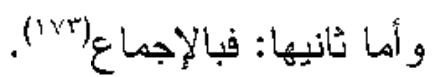
وقد أجيب عنه: بمنع المساو اة، فإن المقارنة

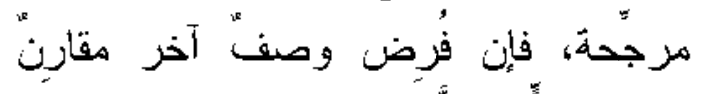

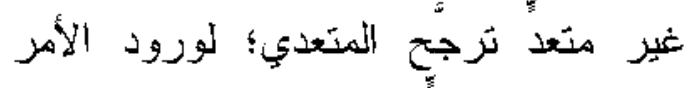

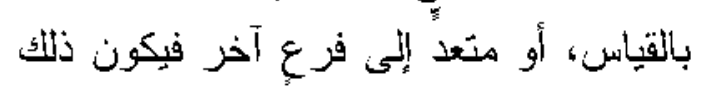

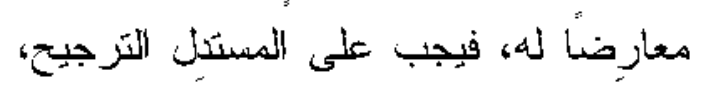

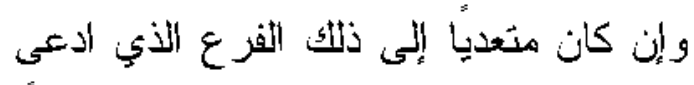

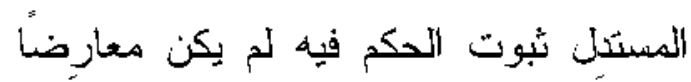

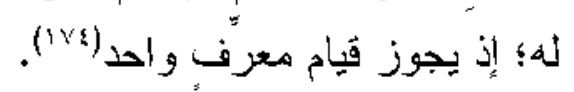
الأليل الثاني:

أن القول بحجيته على التقسير الثَاني يفتح باب الثهذيان: كقولهم في مسألة إزالة النجاسة: مائع لائل

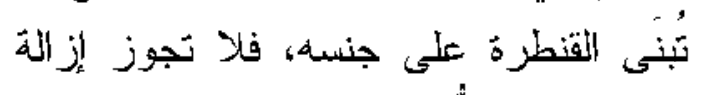
النجاسة به كالثهن.

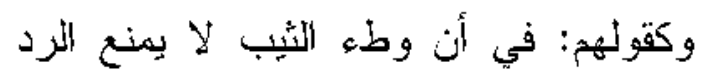

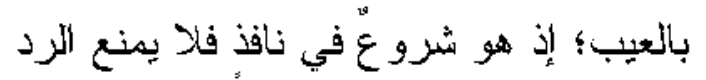

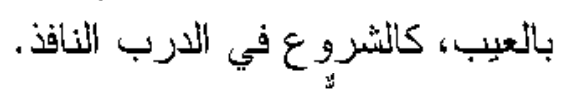
وكقولهم: سعي بين جبلين فلا يكون ركنا،

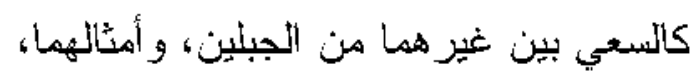

$$
\text { هن الهذيان (1vo). }
$$

وقد أجيب عنه: بأنا لا ندعي أن مجرد

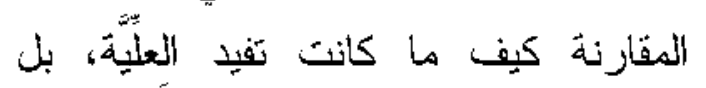

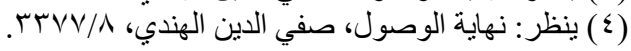

كل نادر بالغالب في جميع الأشثياء فهو

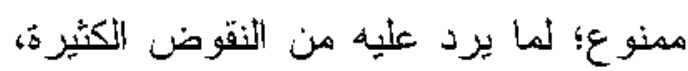

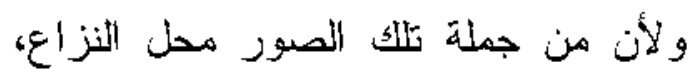

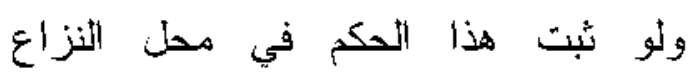
لاستغني عن هذه المقدمة، وإن أريد به أنه

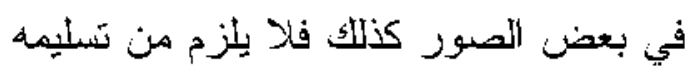

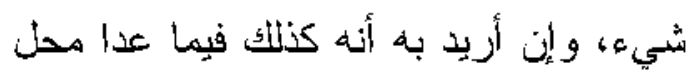

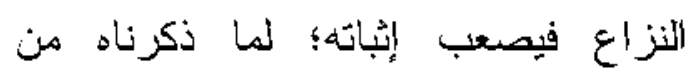

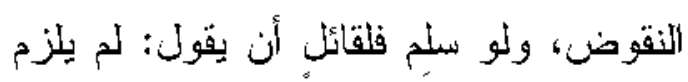

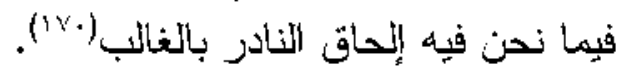

\section{الأليل الثاني:}

أنا إذا رأينا فرس الثقاضي و اققاً: على باب لأبن الأمير غلب على ظننا كون القاضي في دار

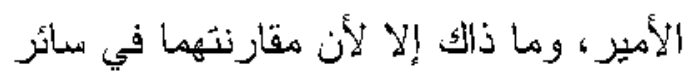
الصور أفاد ظن مقارنتهما في هذه الصورة الأن المعينة (iv')

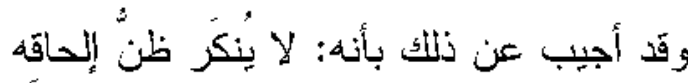

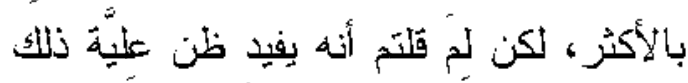

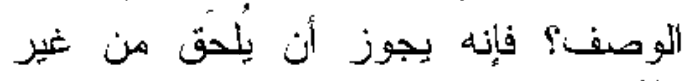

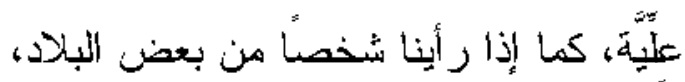

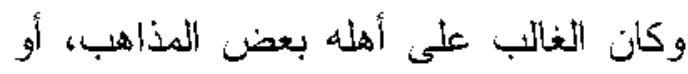

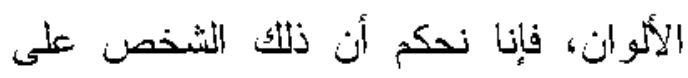

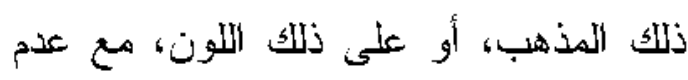

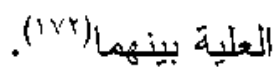

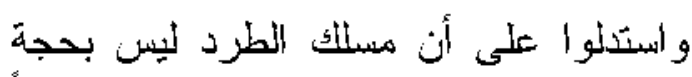
تعلى الثتسير الثناني بما يأني:

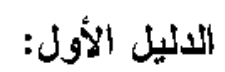

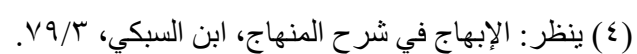

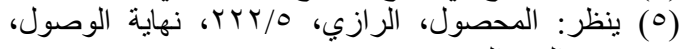

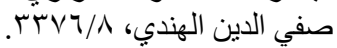

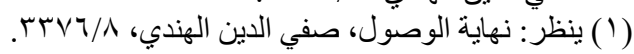


وقال الزركثي:" وهو ظاهر كلام الغزالتي، وقال: إنه رأي المشايخ المتقدمين، وقال:

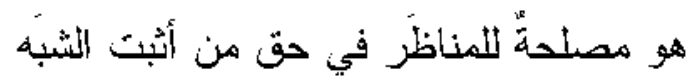

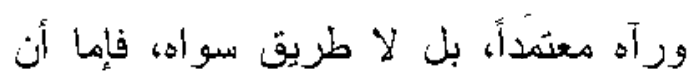

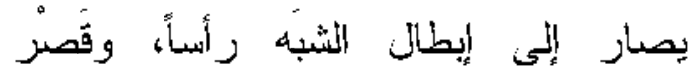

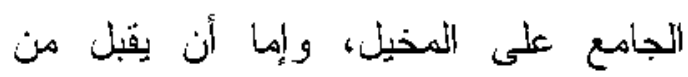

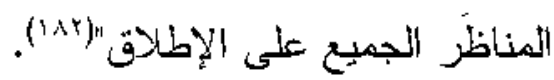

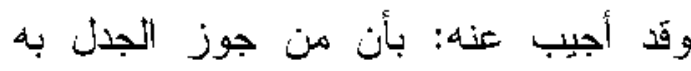

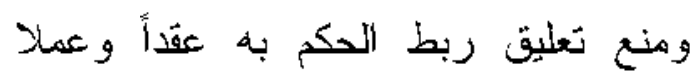

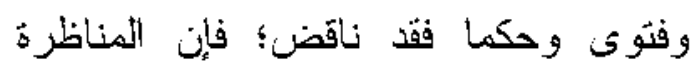

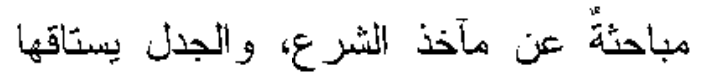

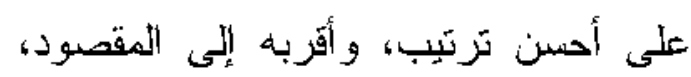

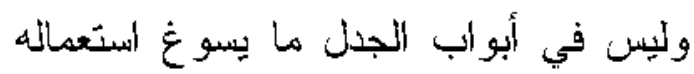

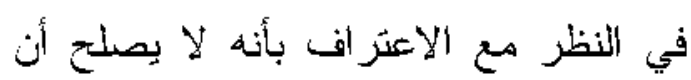

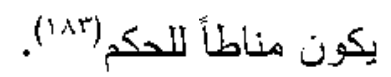
المذهب الخامس: التؤف. وقد ذهب إلى ذلك صفي الدين التوفين الهندي،

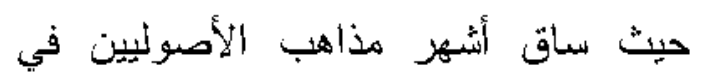
المسألة وأدلتهم هع ذئه ذكر المآخذ عليها

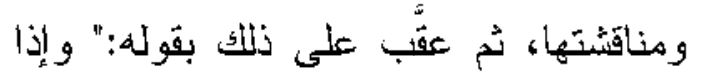

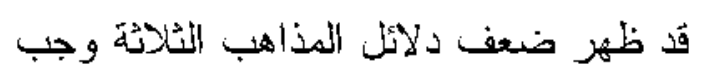

$$
\text { التخوقف" (1) (1). }
$$

\section{الترجيح:}

بعد النظر في أدلة كل قول والموازنة بينها

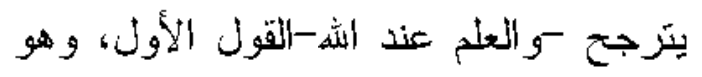
أن مسلأك الطرد ليس بحجة مطلقاً، و أنه

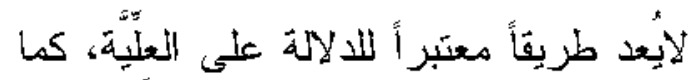
هو مذهب الجمهور من الأصوليين؛ وذلك التك

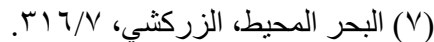

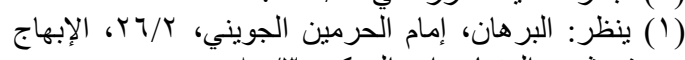

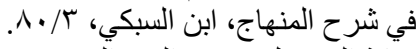

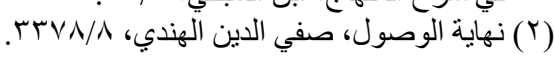

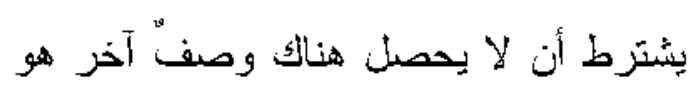

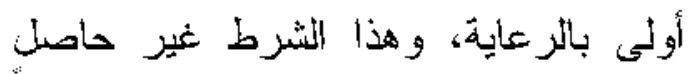

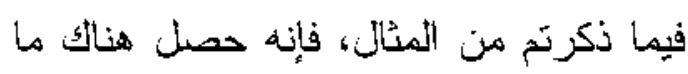

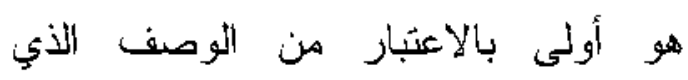

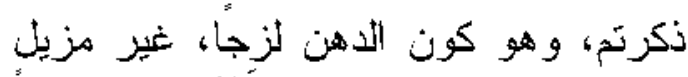

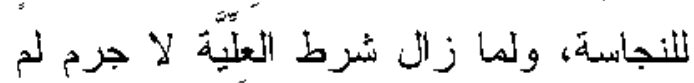

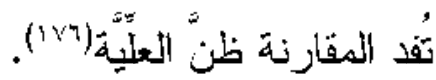

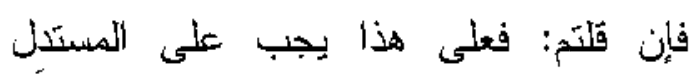

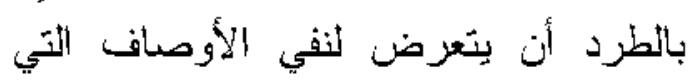

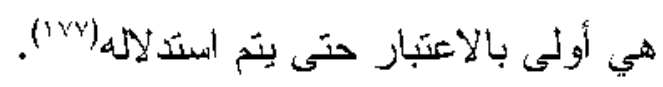

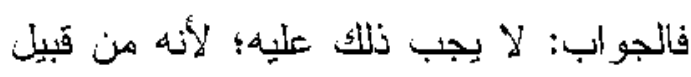

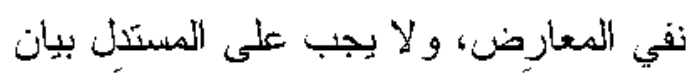

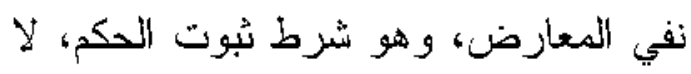

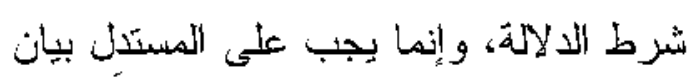

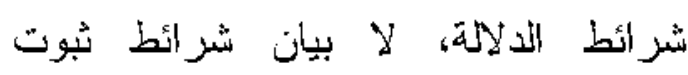
الحكم (ivN)

المذهب الثرابع: أن مسلك الطرد مقبون"

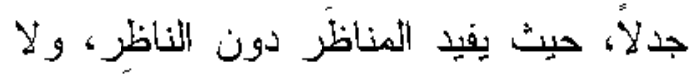

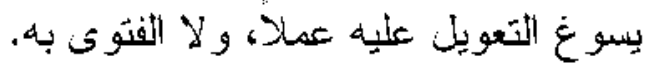

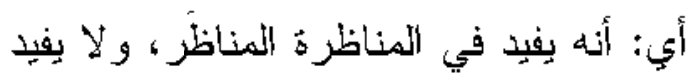

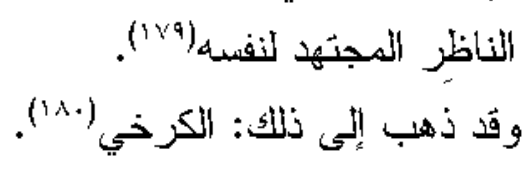
قال المحلي في ببان تعليل فول الكرخي بأنه

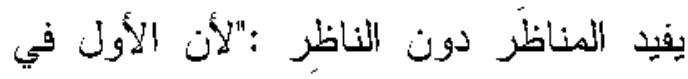

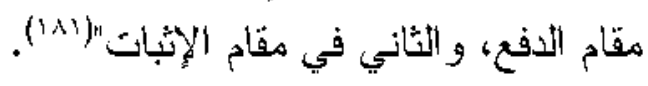

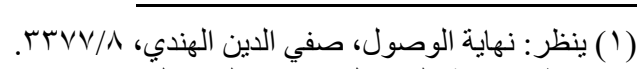

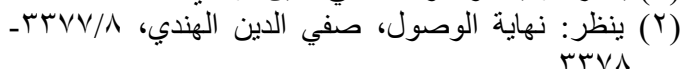
(rTV

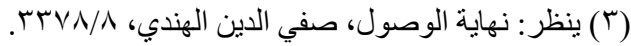

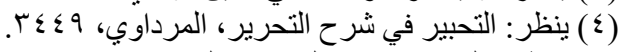

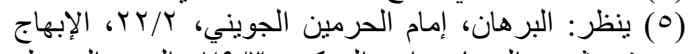

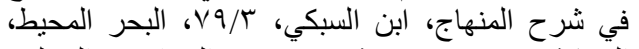

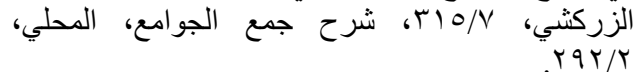

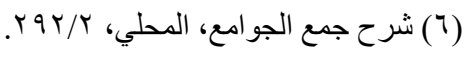




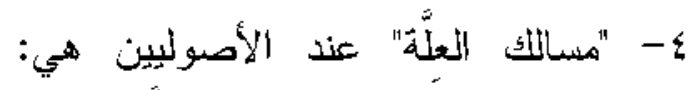

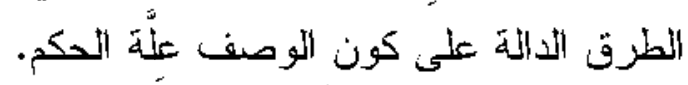

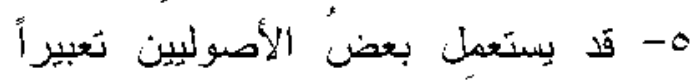

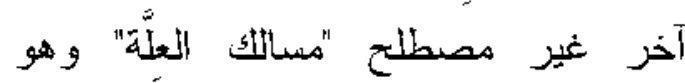

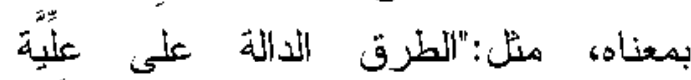

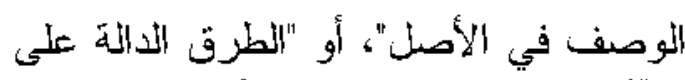

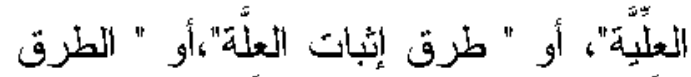

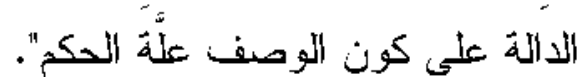

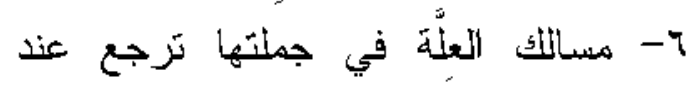

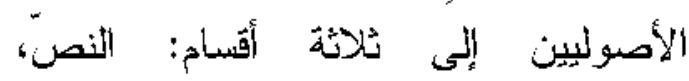
والإجماع ، والانستنباط.

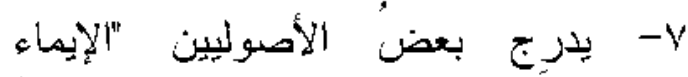

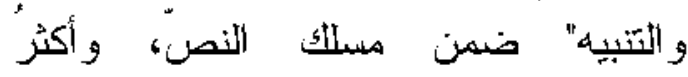
الأصوليين يعتبر النصن" مسلكاً، و "الإنيماء وأكر والتتبيه" مسلكاً آخر؛ حيث العتبروا أن فئن

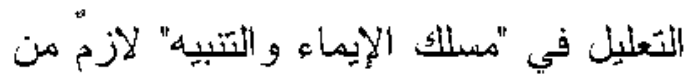

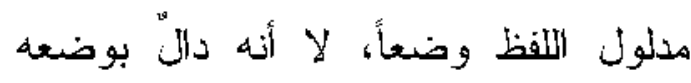
على التعليل.

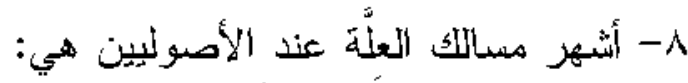

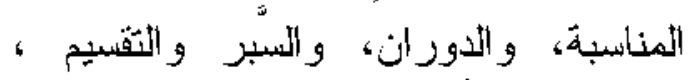

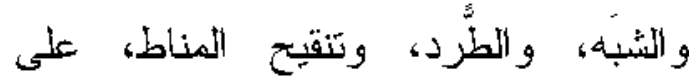

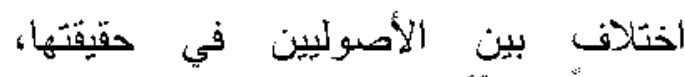

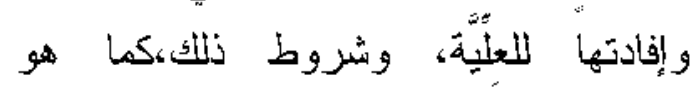
مبسوطٌ في مدونات الأصوليين. 9-الطُّرد في اللغذة: مصدرّ" بمعنى الإبعاد،

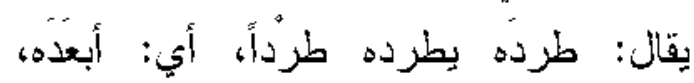
و الإطر اد هو : الثتابع.

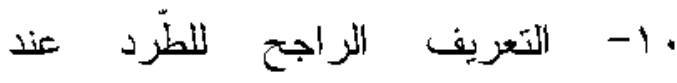

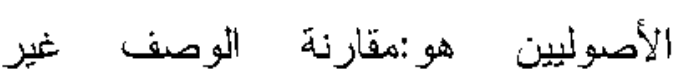

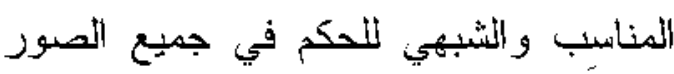
ماعدا المتناز ع فيها.
لقوة أدلثهم، وسلامتها من الاعتراضات

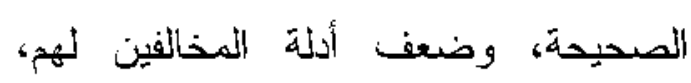
و عدم سلامنها من الاعثر اضات القوية.

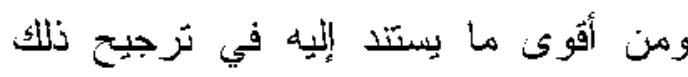

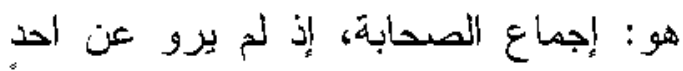

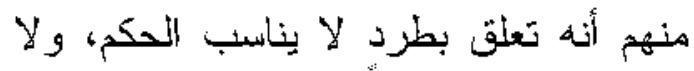

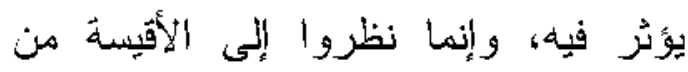

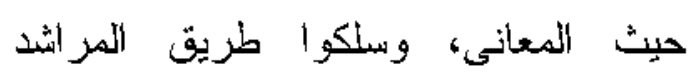
و المصائح التي تثير إلى محاسن الثريعة،

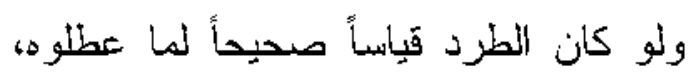

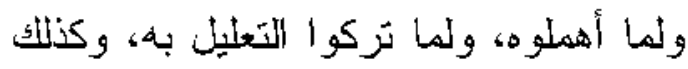
سيائر الأئمة المقتدى بهم من بعدهم.

\section{خاتمة البحث}

بعد أن استعرضت في هذا البحث تعريفات

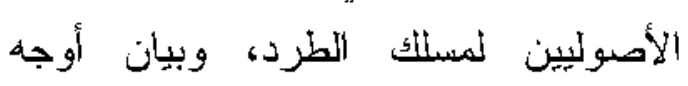

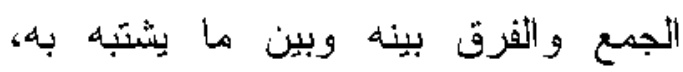
ومذاهب الأصوليين في حجيتّه، وإفادنه

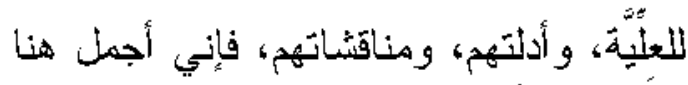

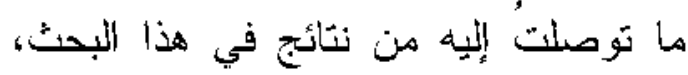
وهي على النحور الآتي:

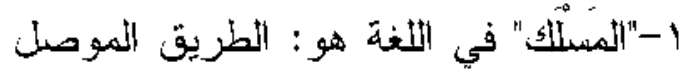

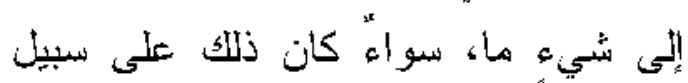

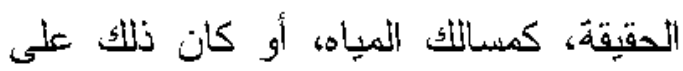
سبيل المجاز ، كمسالك الحق، ومسالتك العلّة.

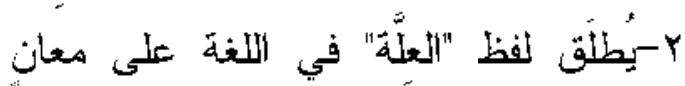

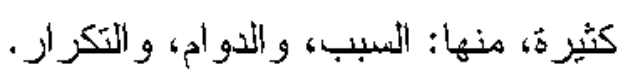

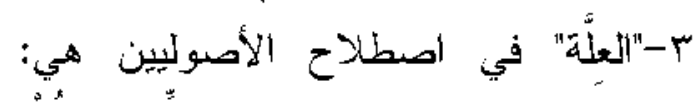

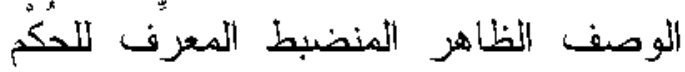

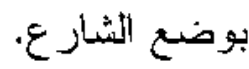


كما أن الوصف في الأوران قد يناسب الحكم وقد لايناسبه ، أما الوصف في الؤرن في الطُّرد فإنه غير مناسب قطعاً، وفي أي حال. لمان.

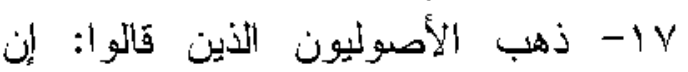

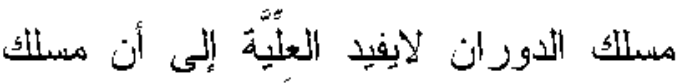

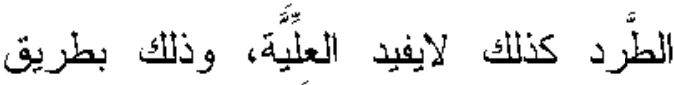

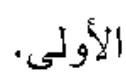

أما الأصوليون الذين ذهبوا إلىى أن مسلك

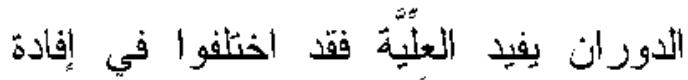

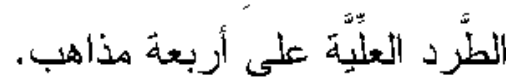

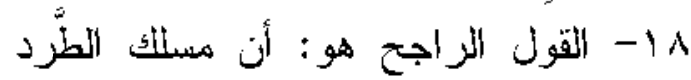
ليس بحجة مطلقاً، وأنه لائعد طريقاً معتبراً

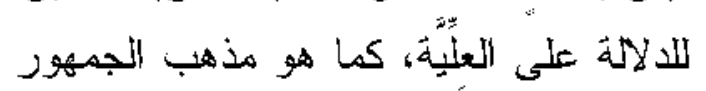

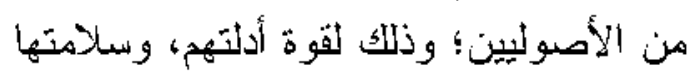
من الاعثراضات الصحيحة، وضعف ألدانة

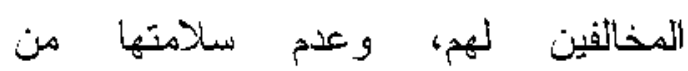
الاعثر اضات الثقوية.

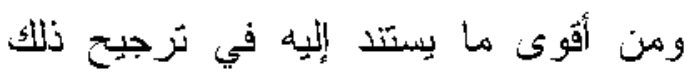

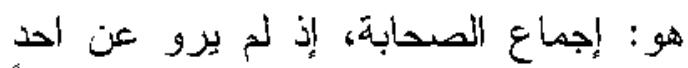

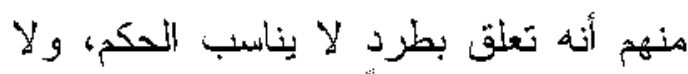

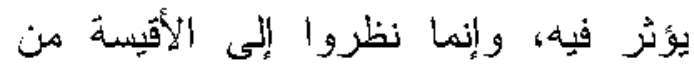

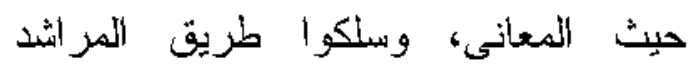

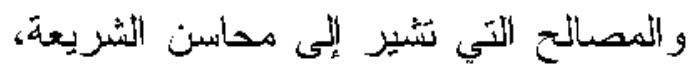

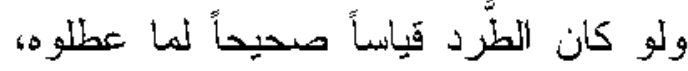

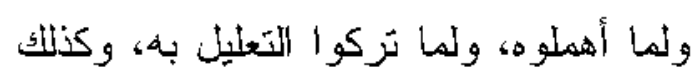
سائز الأئمة المقتدى بهم من بعدهم.

\section{قائمة المراجع أنع}

1. الإبهاج في شرح المنهاج ، ثئي الاين أبو الحسن علي بن عبد الكافي بن

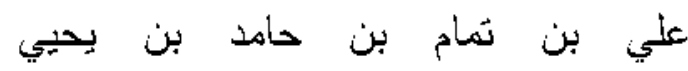

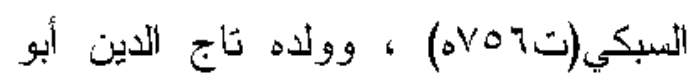

11- الثشبَه لغةً هو : المثتل، والجمع: أثنباه،

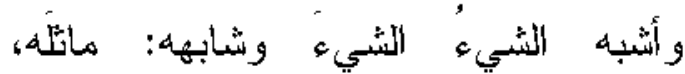
وتثابها واشتبها: أثنبه كل" منهما الآخر حتى الثبتسا. rا الشئه الصطلاحاً هو : الوصف المثارين للحكم الأني لا تظهز فيه المناسبة بعد البحث

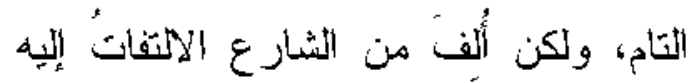
في بعض الأحكام. rا- الفرق بين الطُّرد و الثُبَهَ هو : أن

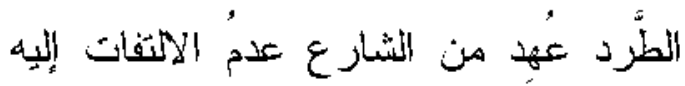
مع عدم وجود المناسبة، وأما الثثبه فإنه الإنه

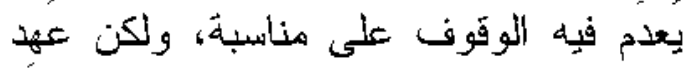

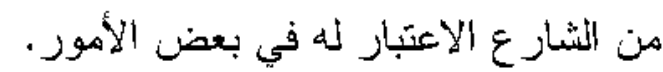

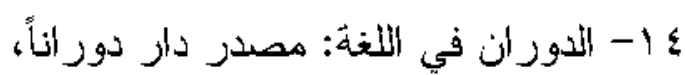

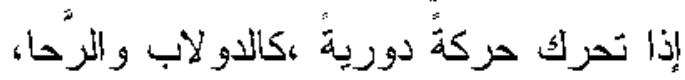
ومنه دورَ العمامة، ودَوْر الخيل. 10- الدوران في اصطلاح الأصوليين هو :أن يثبت الحكم بثبوت وصف، وينتفي عند انتفائه. 17 1-الْفرق بين الطُّرد و الدورانه هو : أن الدوران يتناول وجود الحكم عند وجود الوصف، و انتفاء الحكم عند انتفاء التوصف، فيشمل جانبي الوجود و العدم بين الحكم و الوصف.

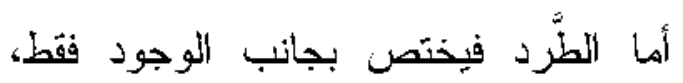

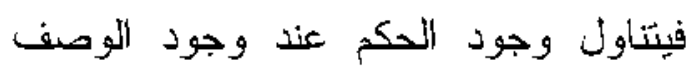

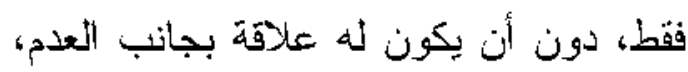

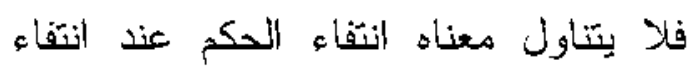
الوصف. 


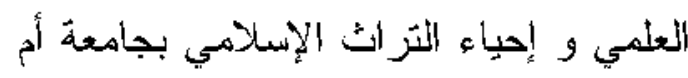

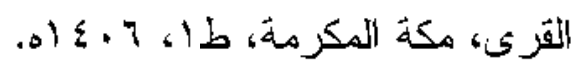

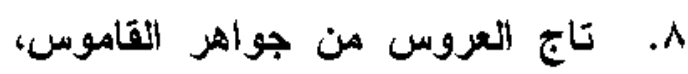

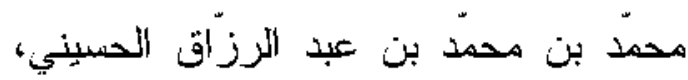

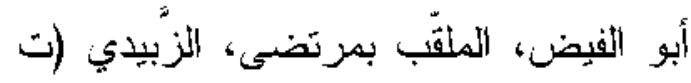

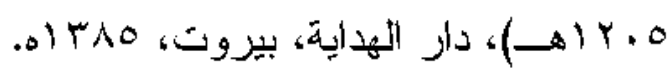
9. التبصرة في أصول الفقه، أبو المحاق

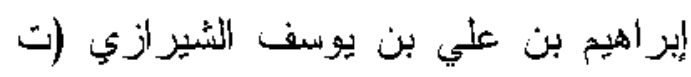

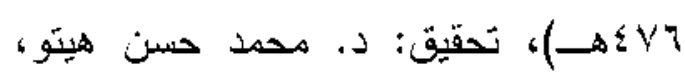

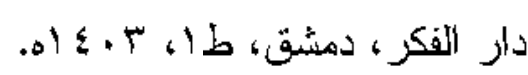

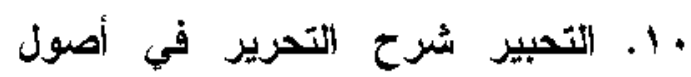

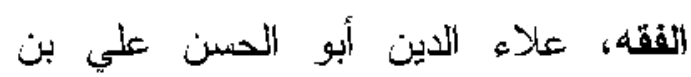

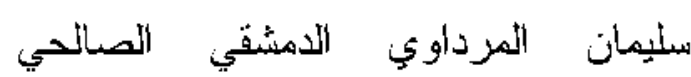

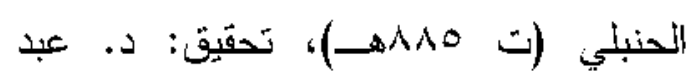

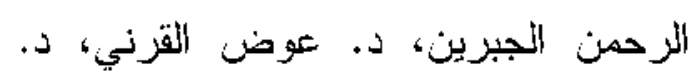

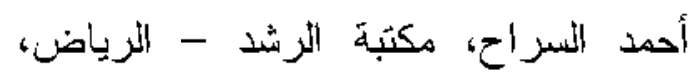

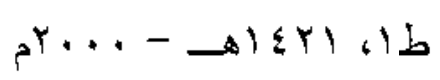

11. تقريرات الثشربيني عنى حاثية البناتي، عبدائرحمن بن محمد الثربيني

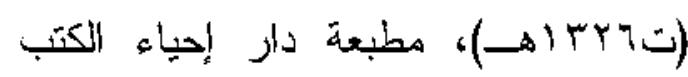

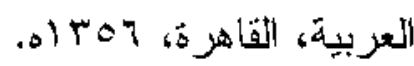
1 1. التوضيح شرح التنقيح في أصول الفقه، صدر الثُريعة عبداله بن همبعود

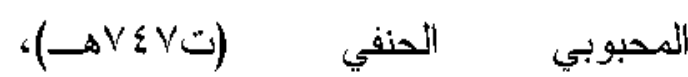
تحقيق :زكريا عمبرات، دار الكثب العلمية، بيزوت، طا. "1. تيسير التحرير على كتاب التحرير في أصول الفقه، محمد أمين بن محمود

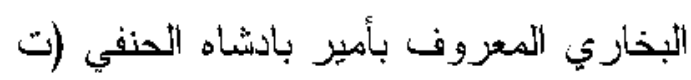
و qYY

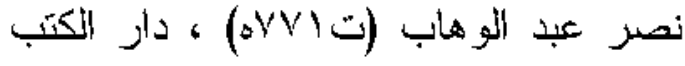

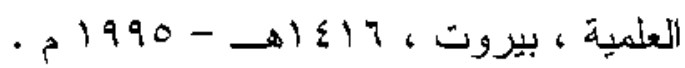
r. الإحكام في أصول الأحكام، أبو الحسن سيد الاين علي بن أبي علي بن الأمبام

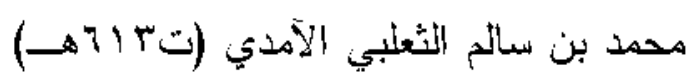

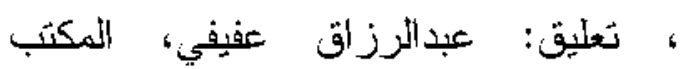
الإندلاهي، بيروت - دمشق.

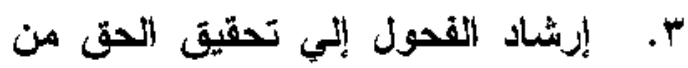

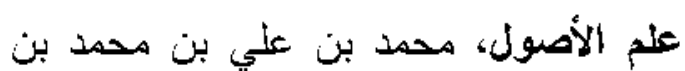

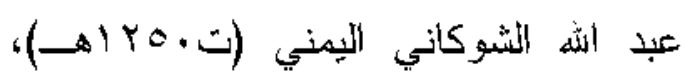

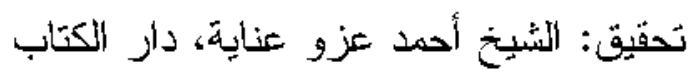

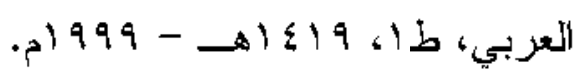

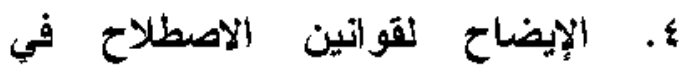

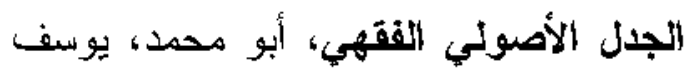

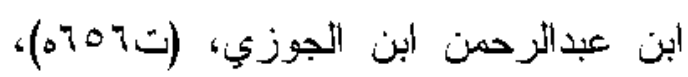

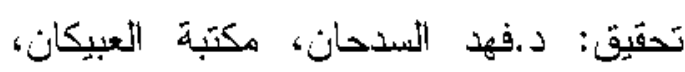

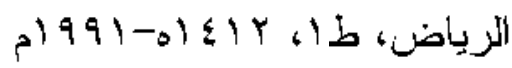
ه. البحر المحيط في أصول الفقه ، أبو أبوان عبداله بدر الدين محمد بن عبدالهه بن بهادر

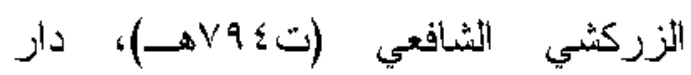

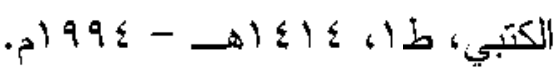

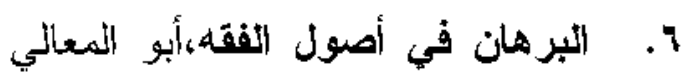

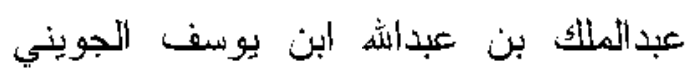

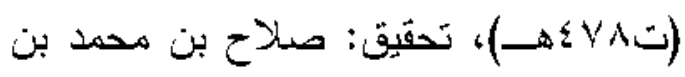

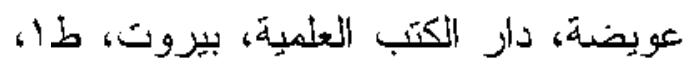
. 199V - هis V. بيان المختصر شرح مختصر أبن الحاجب، شمس الاين أبي ثناء محمود بن

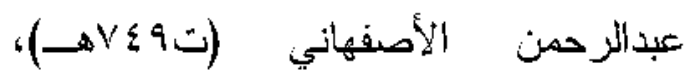
تحقيق د. محمد مظهر بقا، مركز البحث البث 


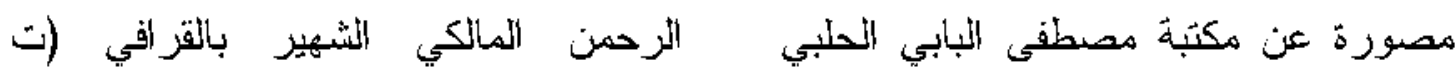

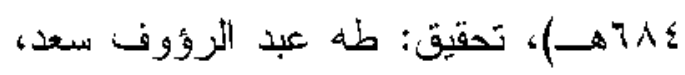

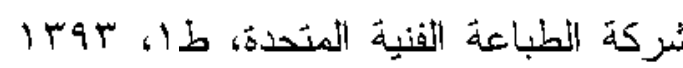

$$
\cdot \hat{\imath} \text { १९४ - }
$$

• . . شرح جمع الجوامع في أصول الثقه،

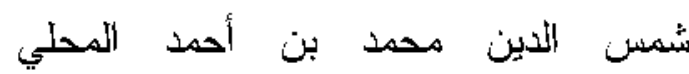

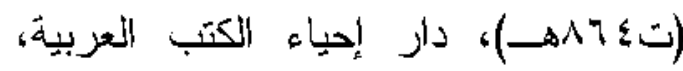

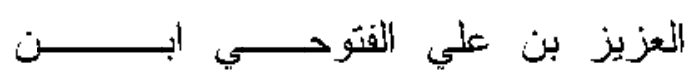

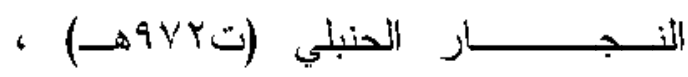

تحقيق :د.محمد الززجيلي ، ود.نزيه حماد

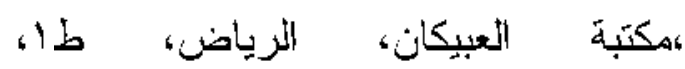

$$
\text { . ) } 99 \vee-ه \mid \wedge
$$

r Y شرح مختصر أبن الحاجب، عضد الأدين بن عبدالزرحن بن أحمد الأيجي

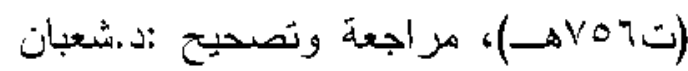
إسيماعبل، مكتبة الكلبات الأزي هرية، القاهرة،

$$
\text { . } 9 \text { ) }
$$

r . شرح مختصر الزوضة، سليمان بن عبد الفوي بن الكريخ الظوفي الصررصري،

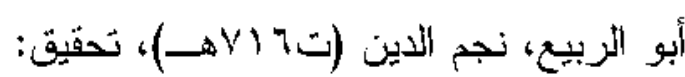
عبد الثه بن عبد المحسن الثنركي، مؤسسة

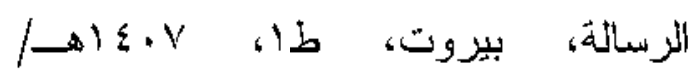
. ) $9 \mathrm{AV}$

צ . شفاء الثظليل في بيان الشبه و المخيل ومسالك التعليل، أبو حامد محمد بن محمد

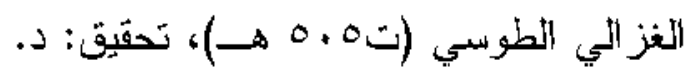

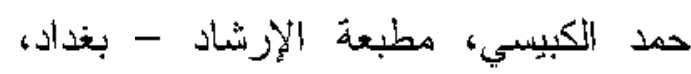

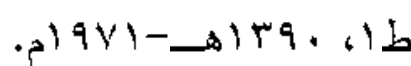

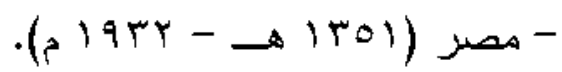
؛1 . جمع الجوامح في أصول اللفقه، تاج الاين أبو نصر عبدالّوهاب بن علي بن عبدالكافي المبكي (ت VV/هـ)، علق عليه وخرج أحاديثة: عبدالمنعم خليل إبراهيم،

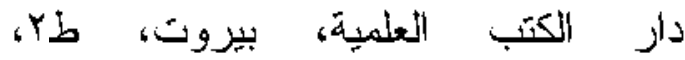

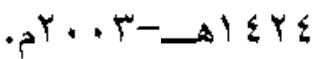

10 أشية البناني نلى شرح المحلى

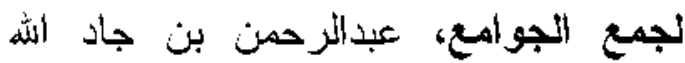

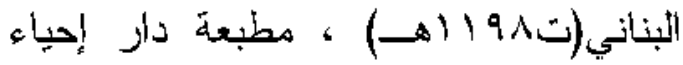

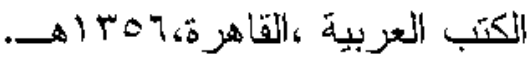

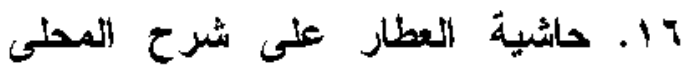
لجميع الجزواميع، حسن بن محمد بن محمود

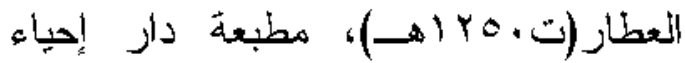

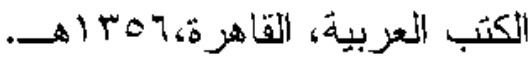

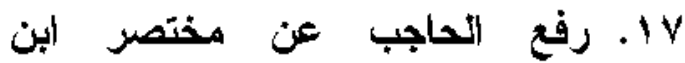
الحاجب، تاج الأدين أبو نصر عبد التو هاب بن الكافي ألسبكي(ت له/PV)، تحقيق: علي محمد معوضن، وعادل أحمد عبد الموجود، عالم

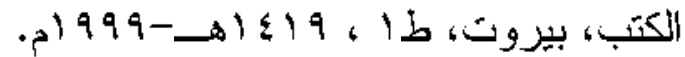

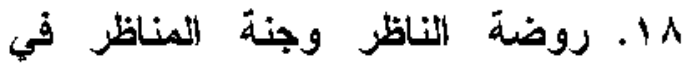
أصول الفقها على مذهب الإمام أحمد بن

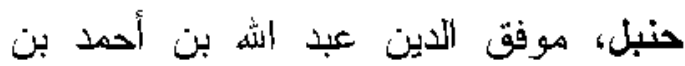
محمد بن قدامة الجماعيلي المقدسي الحنبلي

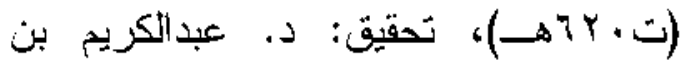
علي ألنملة، مكتبة الرثيد، الثرياض، طع، . म)990-DIडा7 19 1. شرح تثقيح الفصول، أبو الثباس شهاب الدين أحمد بن إدريس بن بعبد 
ابr. كئف الأسرار شرح أصول البزدوي،

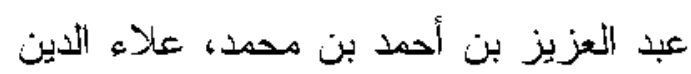

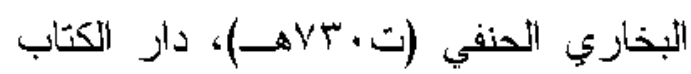
الإِسلخمي.بدون تاريخ.

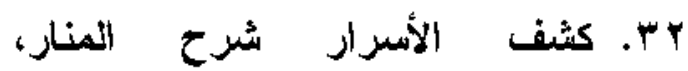

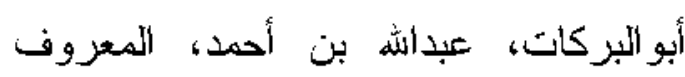

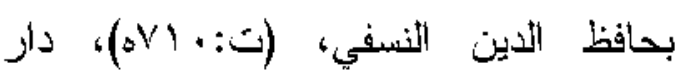
الكتب العلمية، بيروت.

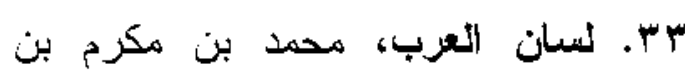

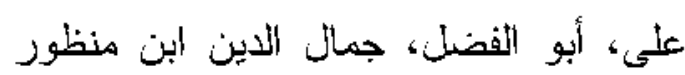

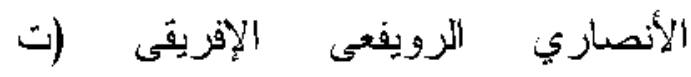

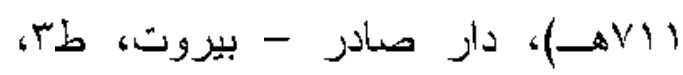

(o) $\leqslant 1 \leqslant$

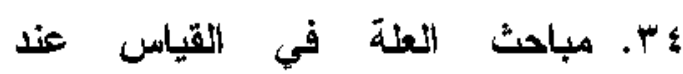

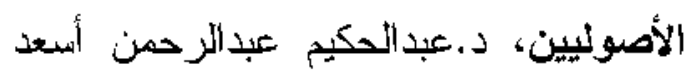

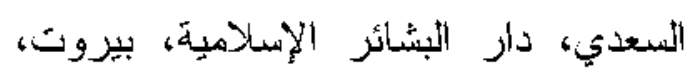

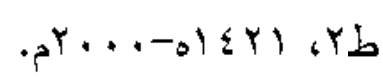

هr. المحصول، أبو عبد الله فخر الدين

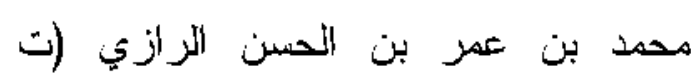

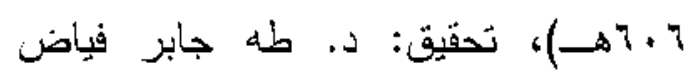

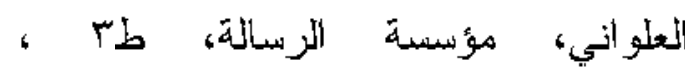

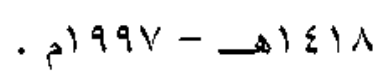

צr. مختصر منتهى السول والأمل في علمي الأصول والجدل، جمال الأدين أبو

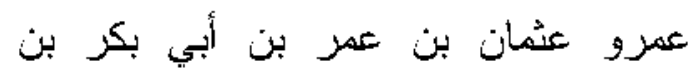

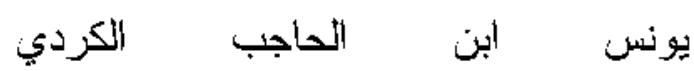
المالكي (ت7 ـ 7هـ)، تحقيق:د.نذير حمادو،

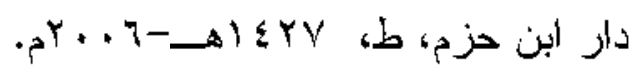

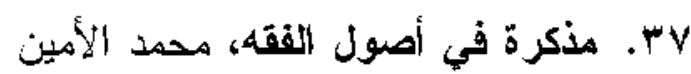

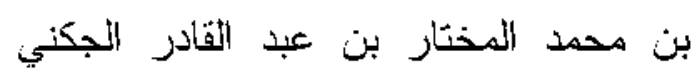

ه. ب. الصحاح تاج اللغة وصحاح العربية،

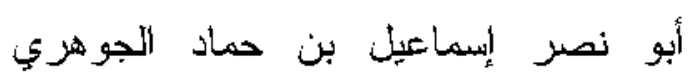

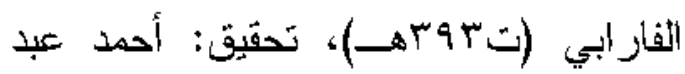

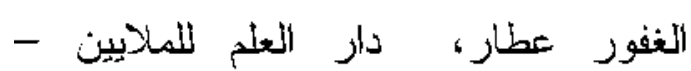

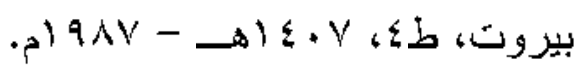

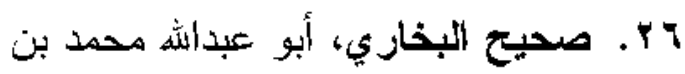

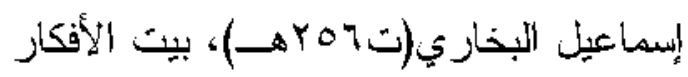

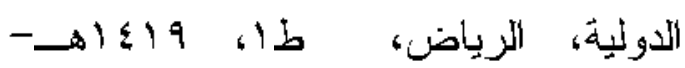
. 1991 rV

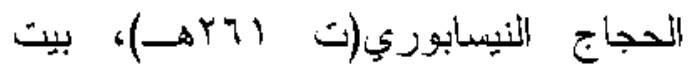

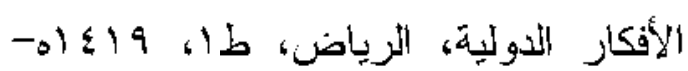
. 1991 1 ب. فواتح الترحموت شرح مسلم الثبوت،

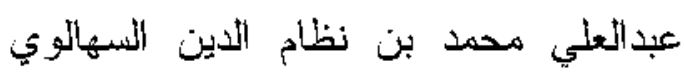

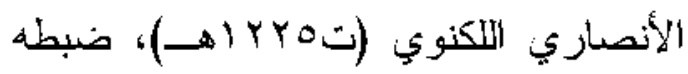

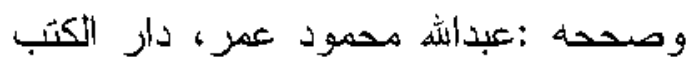

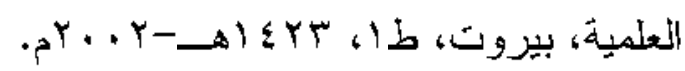

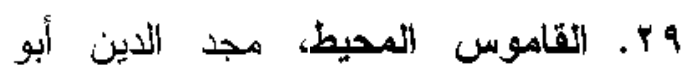

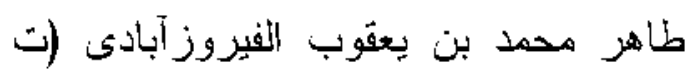

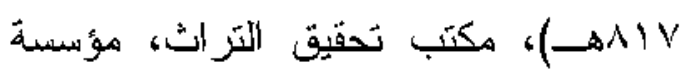

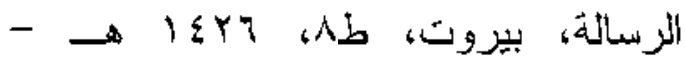

•r. ثواطع الأدنة في الأصول، أبو المظفر، منصور بن محمد بن تبد الجبار

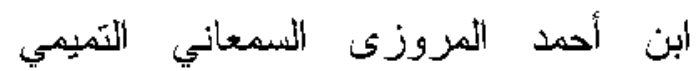
الحنفي ثم الثافعي (ت: A9 الثهــ)، تحقيق:

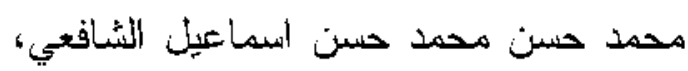

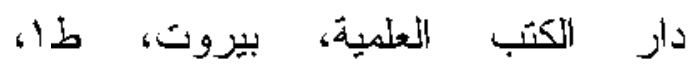
م)999/—1 


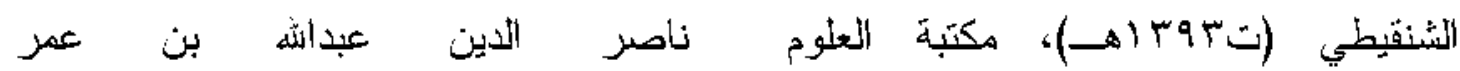

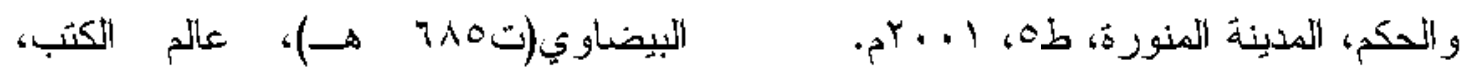

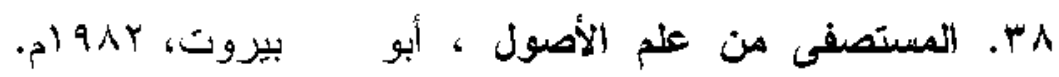

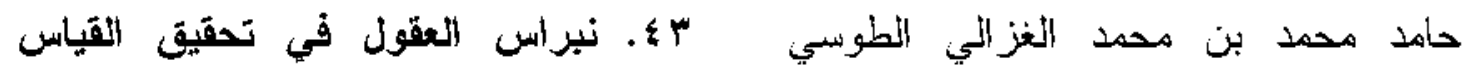

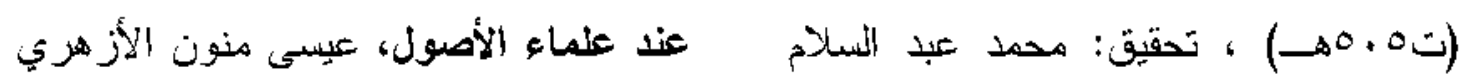

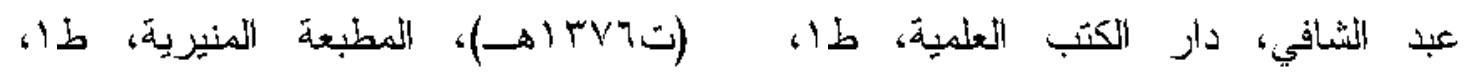

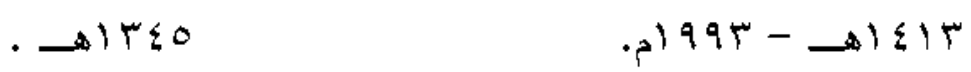

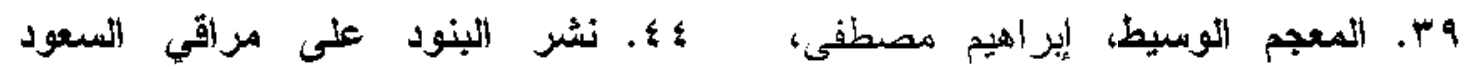

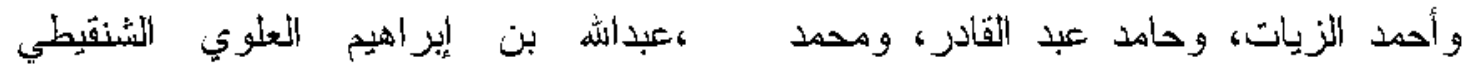

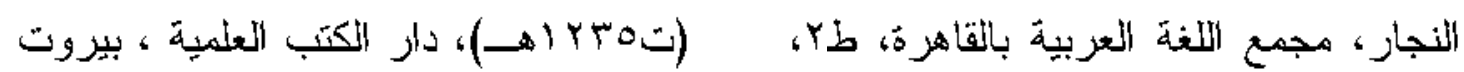

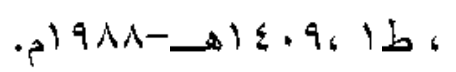
دار الادعوة، تركيا، بدون ثاريخ.

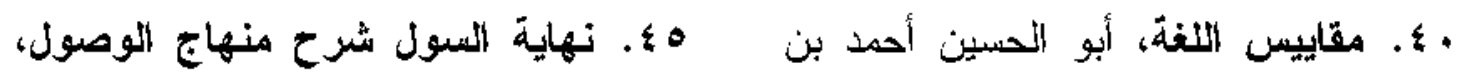

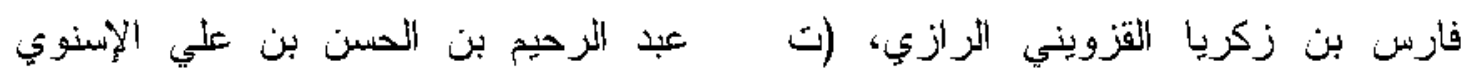

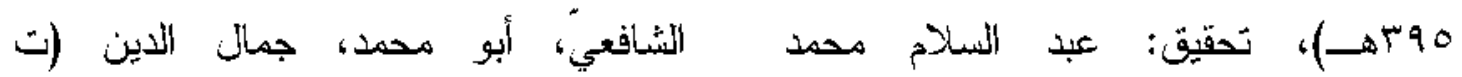
هارون، دار الفكر، القاهزة،

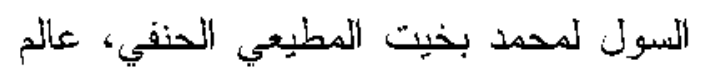
. $919 \times 9$

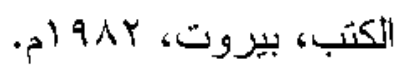
اء. المنخول هن تعليقات الأصول، أبو

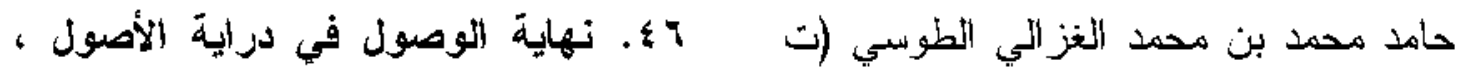

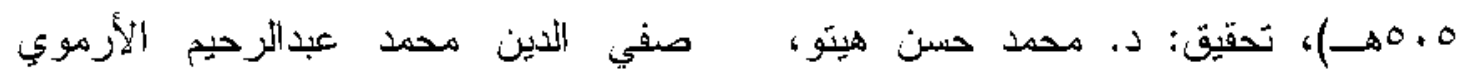

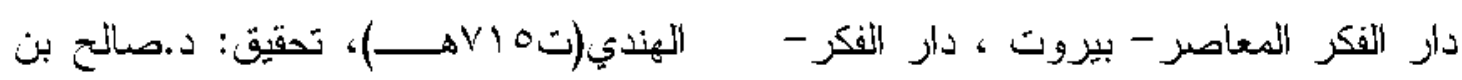

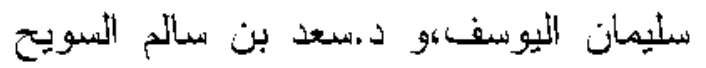

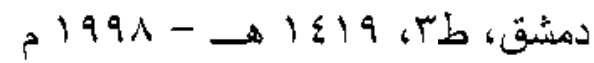

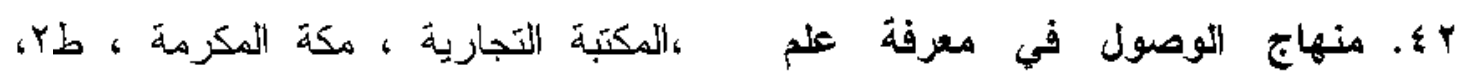
الأصول(مع شرحه نهاية السول للإِسنوي)، 


\title{
Way of the Direct "Attard" in the Originalists' Opinions \\ " Its argument and truth"(English Abstract)
}

\author{
Bilqasim Dhaker Mohammed Alzubaidi
}

The measurement evidence is considered on of the most important evidences of the Shariah Rules.

It is also opinion's origin which the jurisprudence branches from it. The measure evidence leads to the independence of the details of facts and it also leads to measure and know the way of cause / reason and because of this the Originalists considered the research of the cause / reason is the origin or source of searching in the measure subject because knowing the cause / reason of the fact or the action/even in the most important pillar of the measurement.

One of the most important researches that deals with knowing the cause is the research about the ways which explain the reason of the event that had happened, and this process is called: The Ways of the cause.

The way of the Direct "Attard" is considered to be one way of knowing the cause, which the Originalists had tackled it their different studies and opinions.

The researcher showed that all that he had found about this subject was that which had been written by the previous and the recent scholars and according to that he planned to tackle this article and its relation with different Originalists' opinions. 